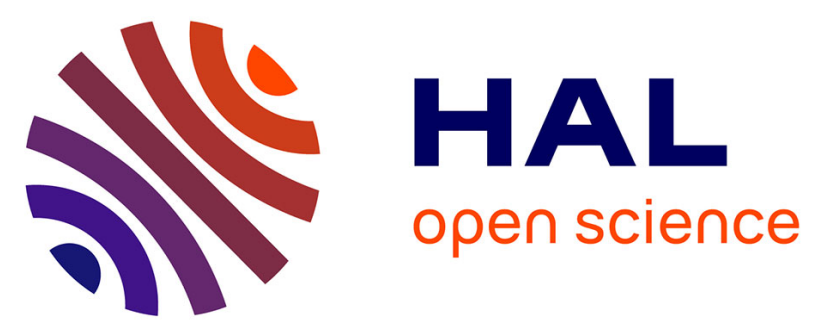

\title{
Numerical modeling of erosion and assimilation of sulfur-rich substrate by martian lava flows: implications for the genesis of massive sulfide mineralization on Mars
}

Raphael J Baumgartner, David Baratoux, Marco Fiorentini, Fabrice Gaillard

\section{- To cite this version:}

Raphael J Baumgartner, David Baratoux, Marco Fiorentini, Fabrice Gaillard. Numerical modeling of erosion and assimilation of sulfur-rich substrate by martian lava flows: implications for the genesis of massive sulfide mineralization on Mars. Icarus, 2017, 296, pp.257-274. 10.1016/j.icarus.2017.06.016 . insu-01544438

\section{HAL Id: insu-01544438 \\ https://hal-insu.archives-ouvertes.fr/insu-01544438}

Submitted on 21 Jun 2017

HAL is a multi-disciplinary open access archive for the deposit and dissemination of scientific research documents, whether they are published or not. The documents may come from teaching and research institutions in France or abroad, or from public or private research centers.
L'archive ouverte pluridisciplinaire $\mathbf{H A L}$, est destinée au dépôt et à la diffusion de documents scientifiques de niveau recherche, publiés ou non, émanant des établissements d'enseignement et de recherche français ou étrangers, des laboratoires publics ou privés.

\section{(ㅇ)(1) $\$$}

Distributed under a Creative Commons Attribution - NonCommercial - NoDerivatives| 4.0 


\section{Accepted Manuscript}

Numerical modeling of erosion and assimilation of sulfur-rich substrate by martian lava flows: implications for the genesis of massive sulfide mineralization on Mars

Raphael J. Baumgartner, David Baratoux, Marco Fiorentini , Fabrice Gaillard

PII: S0019-1035(17)30005-2

DOI: 10.1016/j.icarus.2017.06.016

Reference:

YICAR 12500

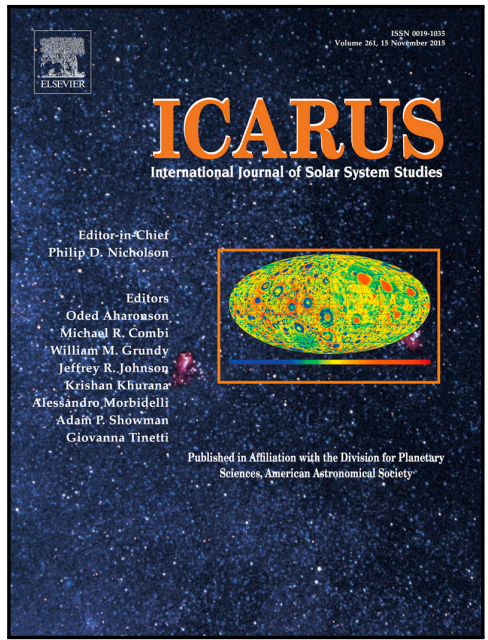

To appear in:

Icarus

Received date: 5 January 2017

Revised date: 31 May 2017

Accepted date:

14 June 2017

Please cite this article as: Raphael J. Baumgartner, David Baratoux, Marco Fiorentini, Fabrice Gaillard, Numerical modeling of erosion and assimilation of sulfur-rich substrate by martian lava flows: implications for the genesis of massive sulfide mineralization on Mars, Icarus (2017), doi: 10.1016/j.icarus.2017.06.016

This is a PDF file of an unedited manuscript that has been accepted for publication. As a service to our customers we are providing this early version of the manuscript. The manuscript will undergo copyediting, typesetting, and review of the resulting proof before it is published in its final form. Please note that during the production process errors may be discovered which could affect the content, and all legal disclaimers that apply to the journal pertain. 


\section{Highlights}

- Numerical modelling of sulfide deposit genesis in martian lava flows.

- Erosion and assimilation of sulfidic substrate triggers sulfide batch segregation.

- Upgrade of precious metals (Ni, Cu and PGE) by sulfide-silicate melt equilibration.

- Sulfate assimilation promotes $\mathrm{SO}_{2}$ degassing rather than sulfide supersaturation.

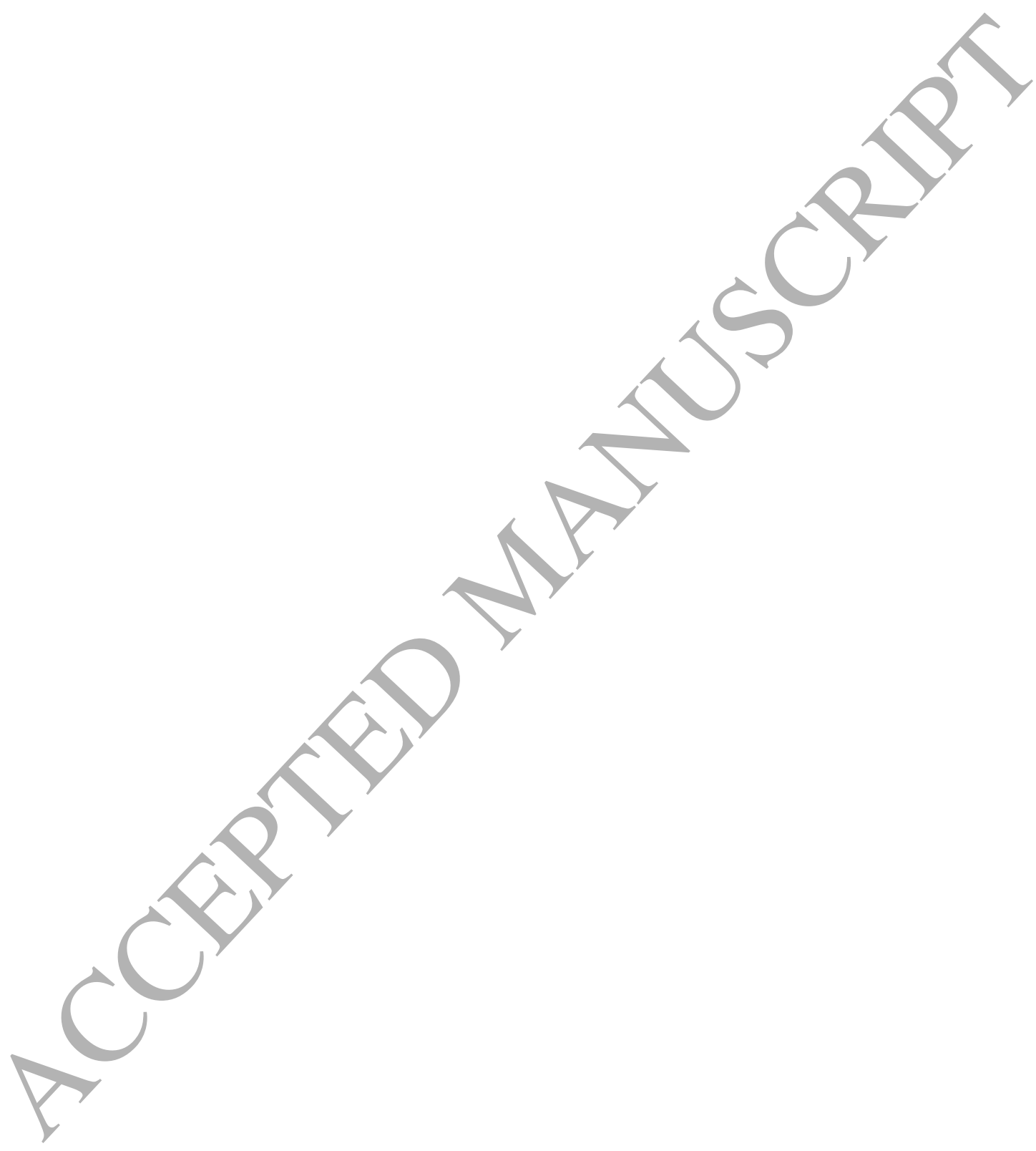


Numerical modeling of erosion and assimilation of sulfur-rich substrate by martian lava flows: implications for the genesis of massive sulfide mineralization on Mars

Raphael J. Baumgartner ${ }^{1, a,{ }^{*}}$, David Baratoux ${ }^{2,3, b}$, Marco Fiorentini ${ }^{1, \mathrm{c}}$, Fabrice Gaillard ${ }^{4, \mathrm{~d}}$

${ }^{1}$ Centre for Exploration Targeting, School of Earth and Environment, ARC Centre of Excellence for Core to Crust Fluid Systems, The University of Western Australia, 6009 Crawley, Australia.

${ }^{2}$ Géosciences Environnement Toulouse, CNRS, IRD and University of Toulouse, 31400 Toulouse, France.

${ }^{3}$ Institut Fondamental d'Afrique Noire, 5005 Dakar, Sénégal.

${ }^{4}$ Institut des Sciences de la Terre d'Orléans, CNRS/INSU, Université d'Orléans, 41071 Orléans, France.

araphael.baumgartner@ research.uwa.edu.au

bdavid.baratoux@get.omp.eu

${ }^{\mathrm{c}}$ fabrice.gaillard@cnrs-orleans.fr

dmarco.fiorentini@uwa.edu.au

*Corresponding author

Abstract

Mantle-derived volcanic rocks on Mars display physical and chemical commonalities with mafic-ultramafic ferropicrite and komatiite volcanism on the Earth. Terrestrial komatiites are common hosts of massive sulfide mineralization enriched in siderophile-chalcophile precious metals (i.e., $\mathrm{Ni}, \mathrm{Cu}$, and the platinum-group elements). These deposits correspond to the batch segregation and accumulation of immiscible sulfide liquids as a consequence of mechanical/thermo-mechanical erosion and assimilation of sulfur-rich bedrock during the turbulent flow of high-temperature and low-viscosity komatiite lava flows. This study adopts this mineralization model and presents numerical simulations of erosion and assimilation of sulfide- and sulfate-rich sedimentary substrates during the dynamic emplacement of (channelled) mafic-ultramafic lava flows on Mars.

For sedimentary substrates containing adequate sulfide proportions (e.g., 1 wt\% S), our simulations suggest that sulfide supersaturation in low-temperature $\left(<1350{ }^{\circ} \mathrm{C}\right)$ flows could 
be attained at $<200 \mathrm{~km}$ distance, but may be postponed in high-temperature lavas flows $\left(>1400{ }^{\circ} \mathrm{C}\right)$. The precious-metals tenor in the derived immiscible sulfide liquids may be significantly upgraded as a result of their prolonged equilibration with large volumes of silicate melts along flow conduits. The influence of sulfate assimilation on sulfide supersaturation in martian lava flows is addressed by simulations of melt-gas equilibration in the C-H-O-S fluid system. However, prolonged sulfide segregation and deposit genesis by means of sulfate assimilation appears to be limited by lava oxidation and the release of sulfur-rich gas.

The identification of massive sulfide endowments on Mars is not possible from remote sensing data. Yet the results of this study aid to define regions for the potential occurrence of such mineral systems, which may be the large canyon systems Noctis Labyrinthus and Valles Marineris, or the Hesperian channel systems of Mars' highlands (e.g., Kasei Valles), most of which have been periodically draped by mafie-ultramafic lavas.

\section{Introduction}

On Earth, Archean to Proterozoic high-temperature komatiite flows are hosts of massive sulfide mineralization enriched in siderophile-chalcophile precious metals ( $\mathrm{Ni}, \mathrm{Cu}$ and platinum-group elements, PGE). The erosion and assimilation of sulfur-rich substrates during the turbulent flow of high-temperature komatiite lavas accounted for sulfide supersaturation and the segregation of sulfide liquids above cotectic proportions (i.e., batch segregation). Their continuous equilibration with replenished silicate melts resulted in the upgrade of precious siderophile-chalcophile metals, and dynamic processes in the flows allowed for their/concentration in physical traps such as local footwall depressions/embayments (Campbell and Naldrett, 1979; Arndt and Jenner, 1986; Lesher and Groves, 1986; Rice and Moore, 2001; Arndt et al., 2005; Barnes and Fiorentini, 2012. On Mars, evidence for mafic-ultramafic volcanic activity is widespread. Orbital and in-situ data suggest physical-chemical commonalities with high-temperature (up to $\sim 1600{ }^{\circ} \mathrm{C}$ ) komatiite and ferropicrite volcanism on the Earth (Baird and Clark 1984; Burns and Fisher 1990; Filiberto, 2008; Grott et al., 2013; Lentz et al., 2011; Baumgartner et al., 2015). These similarities led Burns and Fisher (1990) to speculate whether similar sulfide occurrences have formed on Mars, but this idea gained limited attention since then (c.f., Baumgartner et al., 2015). 
Evidence for orthomagmatic sulfide enrichments at Mars' near surface remains scarce. Inferences from satellite missions are complicated by the general lack of remotely identifiable optical features of sulfides (e.g., via hyperspectral imagery). The areas covered by rovers and landers are necessarily limited (McSween et al., 2008; Grotzinger et al., 2014; Sautter et al., 2014, 2015), and the in-situ investigations did not provide any indications for localized sulfide enrichments. Of course, the long-term preservation of sulfides at the surface would be hindered by their susceptibility to rapid oxidation in contact with the martian atmosphere, and existing sulfide deposits preserved at subsurface levels would only be exposed by large meteoritic impacts. Recent studies advocated that the high sulfate contents of sedimentary deposits may be related to the oxidation and alteration of orthomagmatic sulfides (Dehouck et al., 2012). However, such sulfate enrichments may have formed by volcanogenic sulfur release and/sulfate precipitation during times of intense magmatism (Righter et al., 2009; Gaillard et al., 2013; Filiberto et al., 2016). The shergottite-nakhlite-chassignite (SNC-) meteorites contain orthomagmatic $\mathrm{Fe}-\mathrm{Ni}-\mathrm{Cu}$ sulfides, but the total abundances are within cotectic proportions expected from magmatic differentiation (Lorand et al., 2005; Chevrier et al., 2011).

As similar to komatiite volcanism on the Earth, the study of Baumgartner et al. (2015) suggested that the erosion and assimilation of sulfur-rich substrates by turbulent hightemperature lava flows could have triggered sulfide mineralization events on Mars. However, several key mechanisms in this model require evaluation. Morphological evidence exists for the occurrence of low-viscosity lavas, some of which drained as turbulent channel and tube flows along topographically controlled pathways. Previous studies focused on numerical simulation of the erosive capabilities of such channelled flows, but no attention was drawn on the diverse array of variably consolidated materials on Mars' surface (Williams et al., 2005; Garry et al., 2007; Hurwitz et al., 2010; Jaeger et al., 2010; Hopper and Leverington, 2014; Cataldo et al., 2015), as well as the range of physical and chemical properties of mantle melts and related volcanic surface flows (Baratoux et al., 2011, 2013; Filiberto and Dasgupta, 2015). The effects of sulfide- or sulfate-rich substrate erosion/assimilation on specific physical and chemical lava characteristics, in particular with respect to the properties that control sulfide supersaturation and sulfide batch segregation (sulfide anions, $\mathrm{S}^{2-}$, in melt versus sulfur capacity at sulfide saturation, SCSS), remain unconstrained.

The evaluation of large sulfide endowments on Mars must be a predictive modeling approach. Therefore, this study combines equations accounting for lava erosion (Huppert 
and Sparks, 1985; Williams et al., 1998, 2001, 2005; Cataldo et al., 2015), with formulations for sulfide saturation (Righter et al. 2009; Jugo et al., 2010; Fortin, et al., 2015) in a numerical model allowing for the batch segregation of immiscible sulfide liquids. Various scenarios are examined in which lavas assimilate substrates of variable composition and degree of consolidation. These scenarios include sulfide-rich regolith comparable to the regolith breccias Northwest Africa 7533 and Northwest Africa 7034 (hereafter and NWA 7034 and NWA 7533; Agee et al., 2013; Humayun et al., 2013; Lorand et al., 2015; McCubbin et al., 2016), and the sulfate-rich sedimentary materials observed at landing sites (Squyres and Knoll, 2005; Squyres et al., 2012; Williams et al., 2013; McLennan et al., 2014; Vaniman et al., 2014; Mangold et al., 2016; Thompson et al., 2016).

This study first examines the potential physical flow parameters and erosive capabilities of turbulent lava flows on Mars. The favorable conditions for sulfide supersaturation in terms of sulfide-rich substrate assimilation are then constrained by a sensitivity analysis for the lava, substrate and ambient parameters. The influence of sulfate assimilation is examined by thermodynamic simulations of melt-gas equilibration in the $\mathrm{C}-\mathrm{H}-\mathrm{O}-\mathrm{S}$ fluid system (c.f., Burgisser et al., 2007, Gaillard et al., 2013; Burgisser et al. 2015). Consideration of mantle melting conditions and related melt compositions (Baratoux et al., 2011; Baratoux et al., 2013; Filiberto and Dasgupta, 2015), as well as the diversity and spatial distribution of sulfur-rich lithologies (Bibring et al., 2006; King and McLennan, 2010; Gaillard et al., 2013), allows for inferences on martian igneous environments in which massive sulfide mineralization may have formed.

2. Background - erosion by turbulent lava flows on Mars

Low-viscosity lavas usually inundate the local terrain as laminar flows (Reynolds number, $\mathrm{Re}, \quad 2300$ ) and drain along topographically controlled pathways in which fully developed turbulence ( $\operatorname{Re}>2300)$ may occur. Turbulence accounts for enhanced erosion rates and the development of branching channels that become the main flow pathways. In principal, substrate erosion and assimilation by lava is governed by mechanical and thermal erosion. Efficient heat transfer in convective turbulent flows accounts for thermal erosion rates that are usually one or several orders of magnitude higher in than in conductive laminar flows (e.g., Hulme, 1973; Huppert and Sparks, 1985; Williams et al., 1998, 2005). Mechanical erosion is function of the shear stress of the lava on the ground, and thus increases 
proportionally with the kinetic energy of the flow (Sklar and Dietrich, 1998; Hurwitz et al., 2010, 2013). A third erosion regime is referred to as thermo-mechanical erosion (e.g., Huppert and Sparks, 1985; Williams et al. 1998; Hurwitz et al., 2010, 2013). It differs from pure thermal erosion only in that the substrate is mechanically mobilized as a result of low fractions of substrate melting.

The martian surface contains evidence for erosion by such low-viscosity lava flows. Typical morphological features include channels and tubes at the flanks of shield volcanoes (Fig. 1a and Fig. 1b; e.g., Williams et al., 2005; Bleacher et al., 2007; Vaucher et al., 2009; Lopez et al., 2012; Crown and Ramsey, 2016). Channel systems also emanate at the peripheries of large igneous provinces (e.g., Granicus Valles west of the Elysium province; Fig. 1c), or are associated with low-shield and fissure-fed fluid expulsions. The channels at Athabasca Valles (Fig. 1d), with Amazonian flows that emanate at Cerberus Tholi and drain into Elysium Planitia, are the best studied channel structures that at least partially formed by lava erosion (Plescia, 1990; Hurwitz et al., 2010; Jaeger et al., 2010; Cataldo et al., 2015). The long outflow channels of the Hesperian are usually interpreted as products of enormous water outbursts or the prolonged drainage of meteoric water (Carr, 1979; Milton, 1973; Clifford, 1993; Leask et al., 2007; Warner et al., 2009). Indeed, they share morphological commonalities, with water-carved depressions on Earth, including sinuosity and meandering geometries, streamlined islands and longitudinal grooves. However, channels formed by lava share similar features, which complicates interpretation of their origin on the basis of remote imagery.

A paradigm shift towards erosion by turbulent lava was advocated by recent studies (Leverington, 2004, 2007, 2009, 2011; Leone, 2014), as the planet-wide formation of channel systems by water relies on impractical hydrodynamical and hydrogeological assumptions. Also, limited correspondence exists between hypothesized planet-wide shallow water reservoirs and the abundances of hydrated minerals on Mars' surface. Although controversially discussed, erosion by lava may have been a key mechanism for the formation of several channel systems that were initially interpreted to be exclusively carved by water, such as Hrad Valles (Hopper and Leverington, 2014) and Kasei Valles (Dundas and Keszthelyi, 2014).

\section{Numerical methods}




\subsection{Lava flow and erosion modeling}

The numerical lava flow and erosion equations proposed by Williams et al. $(1998,2001)$ are solved numerically using IDL, and have been extended with several new capabilities. The numerical model is developed for steady-state channel and tube flows in which turbulence is fully developed (Reynolds number, Re, >2300). The simulation requires the specification of ambient conditions and physical-chemical properties of the flowing lava and substrate. Auxiliary equations are used to determine the evolving lava characteristics (i.e., due to lava cooling, fractionation and substrate assimilation) at incremental steps.

The progression of flow is simulated with incremental calculations ( $\mathrm{x}$ ) that are initiated with the calculation of the initial lava flow velocity (v), Reynolds number (Re) and flow thickness (h), using equations for turbulent channel and tube flows:

$$
\begin{aligned}
& v=\sqrt{\frac{g \cdot h \cdot \sin (\alpha)}{\lambda}}(\text { eq. } 1) \\
& \left.\lambda=(0.79 \cdot \ln (\operatorname{Re})-1.64)^{-2} \text { (eq. } 2\right) \text {, } \\
& \operatorname{Re}=\frac{\rho_{1} \cdot \mathrm{Q}}{\mu_{1}} \text { (eq. } 3 \text { ), } \\
& \mathrm{h}=\frac{\mathrm{Q}}{\mathrm{v}} \text { (eq. 4), }
\end{aligned}
$$

in which $Q$ is flow rate per unit width, $\alpha$ is ground slope, $g$ is surface gravity $\left(\sim 3.71 \mathrm{~m}^{2} \cdot \mathrm{s}^{-}\right.$ ${ }^{1}$ ), and $\lambda$ is the Fanning friction factor between lava and substrate (Kakaç et al., 1987); see Table 1 for notations and parameter entities. The bulk density of lava $\left(\rho_{1}\right)$ is calculated from the chemical composition of the melt using the model of Lange and Carmichael (1987), and accounting for the crystal (olivine) fraction (X) in the flow. The incremental mass fraction of crystallization $(\Delta \mathrm{X})$ is calculated following temperature-dependent olivine saturation in the lava assuming constant olivine crystallization rates $(\Delta \mathrm{X} / \Delta \mathrm{T}$; calculated in MELTS; Ghiorsio and Sack, 1995). The bulk viscosity of lava $\left(\mu_{1}\right)$ is computed by the formulations given in Giordano et al. (2008) for the melt fraction, and in conjunction with the Einstein-Roscoe equation for the crystal fraction. Gas bubbles influence the rheology and thermal properties of flowing lava. However, detailed calculations are omitted because these influences remain poorly constrained (Pinkerton and Stevenson, 1992; Manga et al., 1998; Massol and Jaupart, 1999; Cataldo et al., 2015). 
The temperature decrease of lava $(\Delta \mathrm{T})$ over an incremental flow distance (and thus flow time, $\Delta \mathrm{t}$ ) is calculated at each simulation step following Hulme (1973), Huppert and Sparks (1985), and Williams et al. (1998). Heat loss to the base and the top of the flow, assuming the presence of an insulating upper flow crust that is maintained at the solidus temperature of lava $\left(\mathrm{T}_{\text {sol }}\right)$, energy consumed by thermo-mechanical substrate erosion, and heat released by crystal fractionation, is accounted for by:

$$
\begin{gathered}
\rho_{l} \cdot c_{l} \cdot h \cdot \frac{\Delta T}{\Delta t}=-h_{T} \cdot\left(T-T_{m s}\right)-h_{T} \cdot\left(T-T_{s o l}\right)-\frac{h_{T} \cdot\left(T-T_{m s}\right) \cdot E_{h s}}{E_{m s}}+\rho_{l} \cdot h \cdot \frac{\Delta T}{\Delta t} \cdot L_{l} \cdot X^{\prime}(T) \text { (eq. 5), } \\
E_{m s}=\rho_{s} \cdot\left(c_{s} \cdot\left(T_{m s}-T_{a}\right)+f_{m s} \cdot L_{s}\right) \text { (eq. 6), } \\
E_{h s}=\rho_{s} \cdot\left(c_{s} \cdot\left(T_{m s}-T_{a}\right)\right. \text { (eq. 7), } \\
h_{t}=\frac{0.027 \cdot k_{l} \cdot R^{4 / 5} \cdot \operatorname{Pr}^{2 / 5}}{h}\left(\frac{\mu_{1}}{\mu_{s}}\right) \text { (eq. 8), } \\
\operatorname{Pr}=\frac{c_{l} \cdot \mu_{1}}{k_{l}}(\text { eq. 9), }
\end{gathered}
$$

in which $\mathrm{T}$ is lava temperature, $\mathrm{E}_{\mathrm{ms}}$ is thermal energy per unit volume required to melt substrate and initiate thermo-mechanical erosion, $\mathrm{E}_{\mathrm{hs}}$ is thermal energy per unit volume required to heat substrate to laya temperature, $h_{T}$ is convective heat transfer coefficient, and $\operatorname{Pr}$ is Prandtl number The scenario-dependent input parameters are the solidus temperature of lava, the melting temperature of substrate $\left(\mathrm{T}_{\mathrm{ms}}\right)$, the density and specific heat capacity of the substrate $\left(\rho_{\mathrm{s}}\right.$ and $c_{s}$ ), the substrate melting fraction for thermomechanical erosion $\left(f_{\mathrm{ms}}\right)$, the latent heat of substrate melting $\left(\mathrm{L}_{\mathrm{s}}\right)$, the viscosity of molten substrate $\left(\mu_{\mathrm{s}}\right)$, and the ambient temperature $\left(\mathrm{T}_{\mathrm{a}}\right)$. The heat release during crystallization $\left(\mathrm{X}^{\prime}(\mathrm{T})\right)$ is accounted for by the formulation by Huppert and Sparks (1985). The specific heat capacity of lava $\left(c_{1}\right)$ is derived from the data in Lange and Navrotsky (1992). The thermal conductivity $\left(\mathrm{k}_{1}\right)$ and the latent heat of crystallisation of lava $\left(\mathrm{L}_{1}\right)$ may show variation during flow and cooling of lava, but these parameters are held constant given their insignificant influence on the simulation results.

The total lava erosion rate $(\mathrm{u})$ is computed using the equations given in Sklar and Dietrich (1998) and Hurwitz et al. $(2010,2013)$ for mechanical erosion $\left(\mathrm{u}_{\text {mech }}\right)$, as well as Hulme (1973), Huppert and Sparks (1985) and Williams et al. (1998) for thermo-mechanical erosion $\left(\mathrm{u}_{\text {therm }}\right)$ : 


$$
\begin{gathered}
\Omega=\rho_{\mathrm{l}} \cdot \mathrm{g} \cdot \mathrm{Q} \cdot \sin (\alpha) \text { (eq. 10), } \\
\mathrm{u}_{\mathrm{mech}}=\mathrm{K}_{\mathrm{s}} \cdot \Omega \text { (eq. 11), } \\
\mathrm{u}_{\text {therm }}=\frac{\mathrm{h}_{\mathrm{T}} \cdot\left(\mathrm{T}-\mathrm{T}_{\mathrm{ms}}\right)}{\mathrm{E}_{\mathrm{ms}}}(\text { eq. } 12),
\end{gathered}
$$

in which mechanical erosion is function of the flow power per unit width $(\Omega)$ and a mechanical erodibility constant of the substrate $\left(\mathrm{K}_{\mathrm{s}}=\right.$ ratio between the erodibility and the strength of the substrate; Sklar and Dietrich, 1998; Hurwitz et al., 2010). An incremental calculation step is complete with the calculation of the new oxide mass fractions in the melt fraction of lava $\left(\mathrm{M}_{\mathrm{i}}^{\text {melt }}\right)$ through volume and mass balance calculations for $\Delta \mathrm{X}$ and $\Delta \mathrm{S}:$

$$
\begin{gathered}
\Delta S=\frac{\mathrm{u} \cdot \Delta \mathrm{x}}{\mathrm{Q}+\mathrm{u} \cdot \Delta \mathrm{x}}(13), \\
\mathrm{M}_{\mathrm{i}}^{\mathrm{melt}}(\mathrm{x})=\frac{\mathrm{M}_{\mathrm{i}}(\mathrm{x}-1) \cdot(1-\Delta \mathrm{S})+\mathrm{M}_{\mathrm{i}}^{\text {ass }}(\mathrm{x}) \cdot \Delta \mathrm{S}-\mathrm{M}_{\mathrm{i}}^{\mathrm{ol}}(\mathrm{x}) \cdot \Delta \mathrm{X} \cdot(1-\Delta \mathrm{S})}{1-\Delta \mathrm{X} \cdot(1-\Delta \mathrm{S})}(14)
\end{gathered}
$$

in which $\mathrm{M}_{\mathrm{i}}{ }^{\mathrm{Ol}}$ is the mass fraction of oxide $\mathrm{i}$ in olivine, and $\mathrm{M}_{\mathrm{i}}{ }^{\mathrm{Ass}}$ is the mass fraction in the assimilant assuming instantaneous assimilation of the mechanically eroded substrate (see section 6.1.). Melt-olivine partitioning of $\mathrm{Mg}$ and $\mathrm{Fe}$ is estimated by the equations given in Toplis et al. (2005). The new lava composition and temperature is used to calculate oxygen fugacity $\left(\mathrm{fO}_{2}\right.$; Kress and Carmichael, 1991), SCSS (Fortin et al., 2015; Jugo et al., 2010), and the speciation of sulfur $\left(\mathrm{S}^{6+} / \Sigma \mathrm{S}\right.$, in which $\Sigma \mathrm{S}$ is $\left.\mathrm{S}^{2-}+\mathrm{S}^{6+}\right)$ in the melt. The following incremental calculation step is initiated by a fourth-order Runge-Kutta calculation scheme for the thermal evolution of lava (i.e., eq. (5) and eq. (9)).

3.2. Volatile degassing in the C-H-O-S fluid system

The development of a numerical code to simultaneously solve the coupling between thermal evolution, assimilation of sulfate and volatile degassing during flow of lava is beyond the scope of this study. Nonetheless, the potential influence of sulfate assimilation on the thermodynamic stability of volatiles and the sulfur inventory of the melt fraction was approximated using isobaric volatile degassing simulations in the C-H-O-S fluid 
system previously described in Burgisser and Scaillet (2007), Burgisser et al. (2015) and Gaillard et al. (2013). Modeling relies on equilibrium between individual volatile species $\left(\mathrm{H}_{2}, \mathrm{O}_{2}, \mathrm{H}_{2} \mathrm{O}, \mathrm{H}_{2} \mathrm{~S}, \mathrm{~S}_{2}, \mathrm{SO}_{2}, \mathrm{CO}, \mathrm{CO}_{2}\right.$ and $\left.\mathrm{CH}_{4}\right)$ in gas phases:

$$
\begin{aligned}
& \left.\mathrm{H}_{2}^{\text {[gas }]}+\frac{1}{2} \mathrm{O}_{2}^{\text {[gas }]} \leftrightarrow \mathrm{H}_{2} \mathrm{O}^{\text {[gas }]} \text { (eq. } 15\right), \\
& \left.\frac{1}{2} \mathrm{~S}_{2}^{\text {[gas }]}+\mathrm{O}_{2}^{\text {[gas }]} \leftrightarrow \mathrm{SO}_{2}^{\text {[gas ] }} \text { (eq. } 16\right) \\
& \frac{1}{2} \mathrm{~S}_{2}^{\text {[gas }]}+\mathrm{H}_{2} \mathrm{O}^{\text {[gas }]} \leftrightarrow \mathrm{H}_{2} \mathrm{~S}^{[\text {gas }]}+\frac{1}{2} \mathrm{O}_{2}^{\text {[gas ] }} \text { (eq. 17), } \\
& \left.\mathrm{CO}^{[\text {gas }]}+\frac{1}{2} \mathrm{O}_{2}^{\text {[gas }]} \leftrightarrow \mathrm{CO}_{2}^{\text {[gas }]} \text { (eq. } 18\right) \text {, } \\
& \frac{1}{2} \mathrm{CH}_{4}^{\text {[gas] }}+\mathrm{O}_{2}^{\text {[gas ] }} \leftrightarrow \frac{1}{2} \mathrm{CO}_{2}^{\text {[gas ] }}+\mathrm{H}_{2} \mathrm{O}^{\text {[gas] }} \text { (eq. 19). }
\end{aligned}
$$

The equilibrium constants for each reaction are taken from Ohmoto et al. (1977), Robie et al. (1979) and Symonds and Read (1993). Thermodynamic equilibrium between melt and gas is described by:

$$
\begin{aligned}
& \mathrm{H}_{2} \mathrm{O}^{[\text {gas }]}+2 \mathrm{O}^{2-[\text { melt }]} \leftrightarrow 2 \mathrm{OH}^{-[\text {melt }]} \text { (eq. 20), } \\
& \mathrm{H}_{2}^{\text {[gas] }} \leftrightarrow \mathrm{H}_{2}^{\text {[melt] }} \text { (eq. 21), } \\
& S_{2}^{\text {[gas] }}+2 O^{2-[\text { melt] }} \leftrightarrow 2 S^{2-[\text { melt] }}+\mathrm{O}_{2}^{\text {[gas] }} \text { (eq. 22), } \\
& \mathrm{CO}_{2}{ }^{\text {lgas }]}+\mathrm{O}^{2-[\text { melt }]} \leftrightarrow \mathrm{CO}_{3}{ }^{2-[\text { melt }]} \text { (eq. } 23 \text { ), } \\
& 2 \mathrm{FeO}^{[\text {melt }]}+\frac{1}{2} \mathrm{O}_{2}^{\text {[gas }]} \leftrightarrow \mathrm{Fe}_{2} \mathrm{O}_{3}^{[\text {[melt] }} \text { (eq. 24), } \\
& \mathrm{SO}_{4}^{2-[\mathrm{melt}]} \leftrightarrow \mathrm{S}^{2-[\mathrm{melt}]}+2 \mathrm{O}_{2}^{\text {[gas }]} \text { (eq. 25). }
\end{aligned}
$$

The iron-buffered redox condition in the melt phase is determined by eq. (24). Equation (25) considers the redox-dependent stability of sulfate $\left(S^{6+}\right)$ and sulfide $\left(S^{2-}\right)$ in the melt, and thus describes the assimilation and dissolution of sulfate. The equilibrium constants are taken from O'Neill and Mavrogenes (2002), Mungall et al. (2015), Iacono-Marziano et al. (2012), Kress and Carmichael (1991), and Jugo et al. (2010).

Isobaric open-system volatile degassing simulation requires incremental equilibrium calculations considering the physical and chemical parameter variations in the melt and 
exsolved gas fractions. However, this approach suffers from the unknown amount of gas continuously released from the lava flow (i.e., open-system degassing; Iacovino, 2015; Burgisser et al., 2015). Therefore, we consider incremental melt-gas equilibrium calculations without physical separation (closed-system degassing). The simulation first requires the input of total iron in the melt, the mass fraction of gas $\left(\mathrm{w}_{\mathrm{g}}\right)$, as well as the species fugacities $f \mathrm{O}_{2}, f \mathrm{H}_{2} \mathrm{O}$ and $f \mathrm{CO}_{2}$ in the melt at a given equilibrium temperature and equilibrium pressure $\left(\mathrm{P}_{\mathrm{e}}\right)$. The equilibrium reactions in eq. (15) to eq. (25) are jointly solved with solubility laws and allow for the calculation of i) the unknown volatile fugacities and molar fractions in the gas and melt components, and ii) the atomic mass fractions of $\mathrm{C}, \mathrm{H}, \mathrm{O}$ and $\mathrm{S}$ in the system. The same equations are then solved to determine the weight fraction of gas at a specified lava eruption pressure assuming (closed-system) mass conservation of the atomic volatile species determined in the previous step (Burgisser and Scaillet, 2007; Burgisser et al., 2015).

The influence of continuous sulfate assimilation on volatile degassing is simulated by equilibrium calculations following the incremental addition of sulfur species in the substratum (i.e., $\mathrm{XSO}_{4}$ and $\mathrm{XSO}_{4} \cdot 2 \mathrm{H}_{2} \mathrm{O}$ for anhydrous and hydrous sulfate). The tabulated results are implemented in the lava flow and erosion model under the premise that variations in lava temperature and major oxide concentrations due to lava cooling, fractionation and assimilation, are insignificant for degassing rates of the different volatile species, which are dictated by equilibrium pressure, volatile concentrations and redox equilibrium (Burgisser and Scaillet, 2007; Gaillard et al., 2013; Burgisser et al., 2015).

\section{Model scenarios and physical-chemical parameters of lava and substrate}

A variety of scenarios are considered, in which Late Noachian to Amazonian turbulent lava flows interact with variably consolidated sulfide- or sulfate-rich substrates assuming present-day surface temperature $\left(\mathrm{T}_{\mathrm{a}}=-60^{\circ} \mathrm{C}\right)$ on Mars. Previous studies utilized ground slopes and geometries of lava channels derived from remote imagery and laser altimetry to determine the parameters of steady-state lava flows in the turbulent flow regimes, including instantaneous flow thicknesses and velocities, as well as channel erosion rates and potential eruption durations (Williams et al., 2005; Jaeger et al., 2010; Hurwitz et al., 2010; Hopper and Leverington, 2014; Dundas and Keszthelyi, 2014; Cataldo et al., 2015). In accordance with these studies, we consider a range of ground slopes (0.1-1.0 $\left.{ }^{\circ}\right)$ and flow rates per unit width $\left(\mathrm{Q}=200-1400 \mathrm{~m}^{2} \cdot \mathrm{s}^{-1}\right)$ that account for flow thicknesses of $\sim 20-100 \mathrm{~m}$. 
Selected scenarios are investigated in the context of examining favourable conditions for sulfide mineralization formation. Physical-chemical input parameters of lava and substrate are discussed in the following, and summarized in Table 2 and Table 3.

\subsection{Lava parameters}

The lava parameters are selected in light of the evolving conditions of partial melting and cooling of the martian mantle since the Early Noachian, as expressed by the diverse array of magma compositions observed on Mars' surface (McSween et al., 2009; Grott et al., 2013; Filiberto and Dasgupta, 2015). Late Noachian and Hesperian volcanism is represented by the Adirondack-class basalts (hereafter ADR) Humphrey, Adirondack and Mazatzal at Gusev Crater, which presumably represent near-primary mantle melts (mantle melting pressure $\left(\mathrm{P}_{\mathrm{m}}\right)$ and temperature $\left(\mathrm{T}_{\mathrm{m}}\right)$ of $\sim 1.2 \mathrm{GPa}$ and $\sim 1380^{\circ} \mathrm{C}$, respectively; Table 1; Monders et al., 2007; Filiberto et al., 2008; Táble. 2). Constraints of Amazonian volcanism are of two types. Remote sensing studies suggest that Amazonian volcanic provinces are characterized by low-degree mantle melts that equilibrated at high pressure (Stockstill-Cahill et al., 2008; Baratoux et al., 2011). We consider melt compositions inferred from high-pressure melting experiments of the primitive mantle (hereafter LDM; $\mathrm{P}_{\mathrm{m}} \sim 2.2 \mathrm{GPa}$, and $\mathrm{T}_{\mathrm{m}} \sim 1350{ }^{\circ} \mathrm{C}$; Collinet et. al., 2015; Table 2). In contrast, the olivinephyric shergottites provide evidence for high-degree mantle melts even at recent times $(<1$ Ga) as a possible consequence of incomplete degassing of a wet mantle (Balta et al. 2013). This type of volcanism is hereby considered by the high-temperature mantle melt parental to Yamato-980459 (hereafter Y-980459 or Y98; $\mathrm{P}_{\mathrm{m}} \sim 1.2 \mathrm{GPa}$, and $\mathrm{T}_{\mathrm{m}} \sim 1540{ }^{\circ} \mathrm{C}$; Greshake et al., 2004; Musselwhite et al., 2006; Table 2), and serves as a proxy for NoachianHesperian mantle melts that may be hotter than ADR (Filiberto and Dasgupta, 2015). The maximum eruption temperatures $\left(\mathrm{T}_{0}\right)$ are estimated by decompression from the inferred mantle melting pressures $\left(\mathrm{P}_{\mathrm{m}}\right)$ and temperatures $\left(\mathrm{T}_{\mathrm{m}}\right)$ along a mantle adiabat to the surface (Putirka, 2005). Lowering $\mathrm{T}_{0}$ below the liquidus temperatures $\left(\mathrm{T}_{\text {liq }}\right.$; computed in MELTS, Table 2) allows for the simulation of multi-stage magmatic scenarios that include the accumulation of olivine xenocrysts, as typically observed in olivine-phyric shergottites (Greshake et al., 2004; Balta et al., 2015). Thermal conductivity $\left(\mathrm{k}_{1}\right)$ and the latent heat of crystallisation $\left(\mathrm{L}_{1}\right)$ are held constant in the simulations, with estimates that are adopted from Hurwitz et al. (2010). Constraints of oxygen fugacity $\left(f \mathrm{O}_{2}\right.$, hereafter given in log-unit differences from the quartz-fayalite-magnetite buffer, $\triangle \mathrm{QFM}$ ) are required for the volatile 
degassing simulation during sulfate assimilation. Estimates come from the study of olivinephyric shergottites and magmatic rocks analyzed at Gusev Crater, with $f \mathrm{O}_{2}$ that typically falls between QFM-4 and QFM (e.g., Herd et al., 2002; Goodrich et al., 2003; McKay et al., 2004; Schmidt et al., 2013; Balta et al., 2015). A narrow range of low $\mathrm{fO}_{2}$ values (QFM-4 and QFM-2; Table 2) is chosen for this study. Sulfur concentrations are adopted from the Late-Amazonian shergottites $(<500-3000$ ppm S; Shirai and Ebihara, 2004; Righter et al., 2009; Franz et al., 2014; Ding et al., 2015).

\subsection{Substrate parameters}

On Mars, sulfate-rich substrates include regolith and sedimentary rocks (e.g., conglomerates, sandstones and mudstones) as observed at landing sites such as Gale Crater and Endeavour Crater (Williams et al., 2013; Grotzinger et al., 2014; McLennan et al., 2014; Milliken et al., 2014; Vaniman et al., 2014; Mángold et al., 2016; Thompson et al., 2016). These lithologies essentially consist of mafic/intermediate igneous clasts in matrices cemented by clays/sulfates. Therefore, the sulfate-rich model substrate is a 50:50 (by wt\%) mixture of Adirondack-class basalt and soil at Gale Crater (Schmidt et al., 2014). Though evidence for subsurface $\mathrm{H}_{2} \mathrm{O}$ ice suggests that certain flows may interacted with ice-rich substrate, the consequence of pore ice will be investigated in future studies because the number of variable parameters investigated herein is already large. Up to $\sim 8 \mathrm{wt} \% \mathrm{SO}_{3}$ was reported from martian regolith, but analyses at landing sites indicate local enrichments of up to $~ 30-40$ wt\% $\mathrm{SO}_{3}$ (King and McLennan, 2010; Gaillard et al., 2013). We choose volume fractions of hydrous and anhydrous sulfate $\left(\mathrm{XSO}_{4}\right.$ or $\mathrm{XSO}_{4} \cdot 2 \mathrm{H}_{2} \mathrm{O}$, in which $\mathrm{X}$ is a divalent cation) that account for $5 \mathrm{wt} \% \mathrm{SO}_{3}$ (Table 3). The bulk density $\left(\rho_{\mathrm{s}}\right)$ and heat capacity $\left(c_{s}\right)$ is computed from the proportions of clast and matrix components (Schorghofer et al., 2010; Hurwitz et al., 2010) by assuming a pore space fraction $\left(f_{p}\right)$ of 0.1 (Table 3).

The sulfide-rich model substrate is assumed to be chemically and physically equivalent to the regolith breccias NWA 7533, NWA 7034, and pairings (Agee et al., 2013; Humayun et al., 2013; Lorand et al., 2015; McCubbin et al., 2016), which may be common regolith components in (Noachian) low-albedo regions (Cannon et al., 2015). These specimens consist of mafic to intermediate igneous clasts with quenched melt and fine-grained pyroxene- and feldspar-rich matrix material cemented by clay minerals and $\mathrm{SiO}_{2}$-rich glass (Agee et al.,2013; Humayun et al., 2013; McCubbin et al., 2016). Whole-rock analysis of 
NWA 7533 indicates $\sim 0.1 \mathrm{wt} \% \mathrm{~S}$ contained as hydrothermal or sedimentary pyrite (Lorand et al., 2015), but the sulfur-rich nature of the martian crust suggests that regolith materials could contain higher bulk sulfur concentrations. Hence, bulk sulfur concentrations of 1 wt $\%$ are utilized to assess its influence on sulfide liquid segregation and sulfide mineralization events. A bulk density of $3000 \mathrm{~kg} \cdot \mathrm{m}^{-3}$ is estimated for this regolith type. The heat capacity of this type of regolith is assumed to be similar to basaltic crust (Table 3). These estimates have very limited influence on the simulation results.

For both substrate types, the latent heat of fusion $\left(\mathrm{L}_{\mathrm{s}}\right)$ and the melting fraction required for thermo-mechanical erosion ( $\mathrm{f}_{\mathrm{ms}}$ ) are model assumptions (Table 3), which also have limited influence on the simulation results. The substrate melting temperature $\left(T_{\mathrm{ms}}\right)$ is assumed to be equivalent to the melting temperatures of the components that provide structural integrity. Melting of both substrate types may be initiated with plagioclase and clay melting at $\sim 1100{ }^{\circ} \mathrm{C}$ (Drouet et al., 2004; Gavin et al., 2010). Mechanical substrate erodibility constants $\left(\mathrm{K}_{\mathrm{s}}\right)$ have considerable influence on the simulation results. The reader is referred to Hurwitz et al. $(2010,2013)$ for the parameter estimates of strongly consolidated $\left(0.5 \cdot 10^{-8} \mathrm{~Pa}^{-1}\right)$, moderately consolidated $\left(1 \cdot 10^{-8} \mathrm{~Pa}^{-1}\right)$, and unconsolidated $\left(2.5 \cdot 10^{-8} \mathrm{~Pa}^{-1}\right)$ bedrock.

5. Modeling results

\subsection{Physical controls on erosion rates}

A model sensitivity analysis was undertaken for a broad range of input parameters (i.e., lava and substrate type, ground slope, flow rate, eruption temperature and mechanical erodibility constant) aiming to identify the parameters that critically influence substrate erosion and assimilation. We explore the strong influence of ground slope $\left(\alpha=0.1-1.0^{\circ}\right)$ and flow rate per unit width $\left(\mathrm{Q}=200-1400 \mathrm{~m}^{2} \cdot \mathrm{s}^{-1}\right)$ on flow velocity and flow thickness, which on the contrary are relatively insensitive to lava chemistry and temperature. For instance, the low-flux $\left(200 \mathrm{~m}^{2} \cdot \mathrm{s}^{-1}\right)$ emplacement of ADR lava $\left(\mathrm{T}_{0}=\mathrm{T}_{\text {liq }}\right.$; Table 2$)$ over steep ground slope $\left(1.0^{\circ}\right)$ has a flow velocity $\left(\sim 5-6 \mathrm{~m} \cdot \mathrm{s}^{-1}\right)$ that is the same as in the case of high flow rate per unit width $\left(1400 \mathrm{~m}^{2} \cdot \mathrm{s}^{-1}\right)$ and shallow sloped ground $\left(0.1^{\circ}\right)$. However, the latter scenario results in thicker flows ( $\sim 15 \mathrm{~m}$ and $\sim 95 \mathrm{~m}$, respectively; Fig. 2a).

Mechanical erosion is proportional to ground slope, flow rate and the mechanical erodibility of the substrate. Detailed comparison between mechanical and thermo- 
mechanical erosion is done for ADR and Y98 lava emplacement by holding parameters other than flow rate per unit width $\left(\mathrm{Q}=200-1400 \mathrm{~m}^{2} \cdot \mathrm{s}^{-1}\right)$, mechanical erodibility constants $\left(\mathrm{K}_{\mathrm{s}}=0.5 \cdot 10^{-8}\right.$ to $\left.2.5 \cdot 10^{-8} \mathrm{~Pa}^{-1}\right)$ and lava eruption temperature (Table 2) equal. In these scenarios, thermo-mechanical erosion rates of $\sim 1-4 \mathrm{~m} \cdot \mathrm{d}^{-1}$ are viable for Adirondack-class lava emplacement $\left(\mathrm{T}_{0}=1260-1360{ }^{\circ} \mathrm{C}\right)$ and substrate melting at $1100{ }^{\circ} \mathrm{C}$. Hightemperature Y98 lava $\left(\mathrm{T}_{0}=1420-1520{ }^{\circ} \mathrm{C}\right)$ could account for thermo-mechanical erosion rates in the $\sim 4-12 \mathrm{~m} \cdot \mathrm{d}^{-1}$ range (Fig. 2b). Mechanical erosion is usually more efficient than thermo-mechanical erosion, with the exception of high-temperature Y98 lava that interacts with strongly to moderately consolidated substrate at $<600 \mathrm{~m}^{2} \cdot \mathrm{s}^{-1}$ flow rate per unit width (Fig. 2b).

Evolving physical-chemical lava parameters as function of flow distance are reported for ADR, LDM and Y98 lava (with $\mathrm{T}_{0}=\mathrm{T}_{\text {liq }}$; Table 2) emplacing over moderately consolidated sulfide-rich substrate at same ground slope $\left(\alpha=0.1^{\circ}\right)$ and substrate melting temperature $\left(\mathrm{T}_{\mathrm{ms}}=1100{ }^{\circ} \mathrm{C}\right)$, but different flow rates per unit width $(\mathrm{Q}=200,800$ and $\left.1400 \mathrm{~m}^{2} \cdot \mathrm{s}^{-1}\right)$; Fig. 3. The lava thickness increases with flow propagation because of lava cooling, increasing viscosity, and thus decreasing flow velocity (Fig. 3a). Convective heat release is most efficient at high temperatures and accounts for fast cooling in thin flows. Y98 lava with $\sim 25 \mathrm{~m}$ thickness would cool from initially $1500{ }^{\circ} \mathrm{C}$ to $\sim 1300{ }^{\circ} \mathrm{C}$ at $1400 \mathrm{~km}$, but the temperature would only decrease to $\sim 1360-1390{ }^{\circ} \mathrm{C}$ in the case of $\sim 60-65 \mathrm{~m}$ flow height over the same flow distance (Fig. 3b). Adirondack-class lava with lower initial temperature cools at slower rate; i.e., from $1360{ }^{\circ} \mathrm{C}$ to $\sim 1230{ }^{\circ} \mathrm{C}$ in $\sim 25 \mathrm{~m}$ thick flows, and to $\sim 1290-1310{ }^{\circ} \mathrm{C}$ in $\sim 60-65 \mathrm{~m}$ thick flows (Fig. 3b). As opposed to thick flows, rapid cooling of thin flows accounts for viscosities of $>10 \mathrm{~Pa} \cdot \mathrm{s}$, but turbulence is maintained $(\mathrm{Re}$ $>10^{4}$ ) even at flow distances of $1400 \mathrm{~km}$ (Fig. 3c and Fig. 3d).

Mechanical erosion is the dominant erosion regime for the given substrate types, and remains essentially constant during flow progression. The decreases of total erosion and lava contamination rates with flow distance (>30 vol\% at $1400 \mathrm{~km}$; Fig. 3f) are related to the decreases in thermo-mechanical erosion rates (Fig. 3e).

6. Influence of cooling, assimilation and volatile degassing on sulfide supersaturation

\subsection{Assimilation of sulfide-rich substrate}


As magma ascends and erupts onto the surface, the volatilization of sulfur-rich compounds commonly results in decreased sulfur concentrations dissolved in the melt. However, detailed volatile degassing calculations are omitted in the case of assimilation of sulfidic substrate, where volatile degassing would have limited influence on the sulfur inventory of the melt in the flow (see section 6.1.). Sulfide supersaturation may essentially be controlled by the physical and thermal substrate erosion processes, due to which the emplacement of ADR, LDM and Y98 lava (with $1500 \mathrm{ppm} \mathrm{S}$ ) is hereafter simulated for 0.1 and $1.0^{\circ}$ ground slopes, 200 and $1400 \mathrm{~m}^{2} \cdot \mathrm{s}^{-1}$ flow rates per unit width, and under consideration of variable eruption temperatures (Table 2) and mechanical erodibility constants for strongly consolidated to unconsolidated substrates $\left(\mathrm{K}_{\mathrm{s}}=0.5 \cdot 10^{-8}\right.$ to $\left.2.5 \cdot 10^{-8} \mathrm{~Pa}^{-1}\right)$.

Ground slope and the mechanical substrate erodibility, as opposed to volume flux and physical-chemical lava parameters (i.e., chemical composition, temperature and rheology), dictate (mechanical) erosion, sulfur assimilation and sulfide immiscibility. For instance, irrespective of the flow rate and eruption temperature of ADR lava, sulfide supersaturation at $<50 \mathrm{~km}$ may be obtained by the interaction with unconsolidated substrate at steep ground slopes $\left(1.0^{\circ}\right)$, but is not reached within $\sim 50-200 \mathrm{~km}$ in the case of strongly consolidated substrate. Sulfide supersaturation is deferred at $0.1^{\circ}$ ground slope, at which the flow is less energetic and mechanical erosion less efficient. Sulfide immiscibility takes place at $\sim 180 \mathrm{~km}$ if moderately consolidated substrate, low eruption temperature $\left(1260{ }^{\circ} \mathrm{C}\right)$ and low flow rate per unit width $\left(200 \mathrm{~m}^{2} \cdot \mathrm{s}^{-1}\right)$ is considered, but is not reached until $>1000$ $\mathrm{km}$ in the end-member scenario of strongly consolidated substrate, high eruption temperature $\left(1360{ }^{\circ} \mathrm{C}\right)$ and high flow rate per unit width $\left(1400 \mathrm{~m}^{2} \cdot \mathrm{s}^{-1}\right)$; Fig. 4a.

The latter results illustrate the positive effects of low flow rates and low eruption temperatures on the attainment of sulfide supersaturation. The melt SCSS trajectories in cooler flows are shifted towards lower values than in hotter ones, but yet show narrower variations with flow distance (Fig. 4a and Fig. 4c). As dependent on the model scenario, the SCSS of ADR lava with $1360{ }^{\circ} \mathrm{C}$ decreases from $\sim 3000 \mathrm{ppm} \mathrm{S}$ to $\sim 2400-2900 \mathrm{ppm} \mathrm{S}$ at the intersection with the $S^{2-}$ trajectory, but experiences only limited variation ( 2200$2400 \mathrm{ppm} \mathrm{S}$ ) at lower eruption temperatures (Fig. 4a). While low lava flow rates account for low mechanical erosion and sulfur assimilation rates, the flows are thinner and cool quicker than thicker flows (Fig. 3b), due to which the SCSS trajectories are steeper and promote sulfide segregation closer to the source. The SCSS of a silicate melt is dependent on its chemistry (particularly $\mathrm{Fe}^{2+}$ as a ligand for $\mathrm{S}^{2-}$; O’Neill and Mavrogenes, 2002; Fortin et al., 2015). Nevertheless, compositional differences between the chosen lava types 
and any variations due to fractional crystallization and substrate erosion during flow have neglectable influence on the SCSS and sulfide batch segregation.

\subsection{Assimilation of sulfate-rich substrate}

The oxidative property of sulfate requires detailed consideration in the erosion simulation of sulfate-rich sedimentary materials. Lava oxidation may happen in response to the (partial) reduction of sulfate to sulfide $\left(S^{6+} \rightarrow S^{2-}\right)$ in the melt, but compensated by the simultaneous oxidation of ferrous to ferric iron $\left(\mathrm{Fe}^{2+} \rightarrow \mathrm{Fe}^{3+}\right)$, as well as the partial transformation of $\mathrm{SO}_{3}$ to $\mathrm{SO}_{2}$ and other volatile sulfur compounds in gas phases. The equilibrium data for eq. (16) $\mathrm{S}_{2}{ }^{\text {[gas] }} \leftrightarrow \mathrm{SO}_{2}{ }^{\text {[gas] }}$, eq. (22) $\mathrm{S}_{2}{ }^{\text {[gas] }} \leftrightarrow \mathrm{S}^{2-[\text { melt] }}$ and eq. (25) $\mathrm{SO}_{4}{ }^{2-}$ ${ }^{[m e l t]} \leftrightarrow S^{2-[m e l t]}$ implies that the capacity of silicate melts to reduce $S^{6+}$ to $S^{2-}$ is primarily dependent on the pressure and the redox conditions, Table 4 summarizes degassing calculations for anhydrous and hydrous sulfates. They combine the $\mathrm{FeO}$ concentrations and ascertained eruption temperatures of ADR and $\mathrm{Y} 98$ lava $(\mathrm{FeO}=16 \mathrm{wt} \%$ and $20 \mathrm{wt} \%$, and $\mathrm{T}_{0}=1350$ and $1500{ }^{\circ} \mathrm{C}$, respectively), different equilibrium pressures $\left(\mathrm{P}_{\mathrm{e}}=5\right.$ and $\left.100 \mathrm{bar}\right)$, as well as oxygen fugacity $\left(f \mathrm{O}_{2}=\mathrm{QFM}-4\right.$ and QFM-2) and sulfur $(\mathrm{S}=0,1500$ and 3000 ppm S) estimates for mantle melts (Table 2). Five bar equilibrium pressure may correspond to the depth-averaged or basal load pressure in $\sim 80 \mathrm{~m}$ or $\sim 40 \mathrm{~m}$ flows with $3300 \mathrm{~kg} \cdot \mathrm{m}^{3}$ density. The simulation at 100 bar allow to assess the influence of high pressure on degassing rates.

Figure 5 illustrates the strong controls of pressure and initial oxygen fugacity on the reduction of sedimentary sulfate to $\mathrm{S}^{2-}$. At 5 bar, the interaction of anhydrous sulfate $\left(\mathrm{XSO}_{4}\right)$ with strongly reduced $\left(f \mathrm{O}_{2}=\mathrm{QFM}-4\right)$ ADR lava containing $1500 \mathrm{ppm} \mathrm{S}$ may reduce $\sim 0.2 \mathrm{wt} \% \mathrm{SO}_{3}$ until a maximum of $\sim 2100 \mathrm{ppm} \mathrm{S}^{2-}$ in the melt. The positive effect of higher pressure on total sulfur $\left(\mathrm{S}^{2-}\right.$ or $\left.\mathrm{S}^{6+}\right)$ in the melt is manifested by the simulations at 100 bar, where a maximum of $\sim 2800$ ppm S is reached (Fig. 5a and Table 4). These values are tipping points due to melt oxidation (Fig 5b), above which less $\mathrm{S}^{2-}$ is gained by the reduction of $\mathrm{SO}_{3}$ than released as $\mathrm{SO}_{2}$ (Fig. 5c). The increased production of $\mathrm{SO}_{2}$ at the expense of $\mathrm{S}^{2-}$ in the melt accounts for the relaxation of the $\mathrm{fO}_{2}$ trajectory. The simulation of less reduced ADR melt $\left(f \mathrm{O}_{2}=\mathrm{QFM}-2\right)$ at 5 bar is accommodated by the instantaneous expulsion of $\mathrm{SO}_{2}$ (Fig. 5c), thus resulting in peak concentrations of $\sim 1750 \mathrm{ppm} \mathrm{S}{ }^{2-}$ only (Fig. 5a). Up to $3000 \mathrm{ppm} \mathrm{S}$ is chosen for the high-temperature Y98 lava because of comparatively higher SCSS at eruption ( 4000-5000 ppm S for Y98 at 1420-1520 ${ }^{\circ} \mathrm{C}$; Fig. 
4c). The small differences between the simulations of Y98 and ADR melt (Fig. 5d to Fig. 5f) at respective oxygen fugacities and pressures demonstrate the limited influence of melt composition and temperature on the sulfate simulations. The addition of $\mathrm{SO}_{3}$ to reduced Y98 melt that contains 1500 ppm S at 5 bar results in a maximum 2000 ppm S dissolved in the melt (Fig. 5d), which is only $\sim 100$ ppm less than in the case of ADR (Fig. 5a). The reduction of hydrous sulfate $\left(\mathrm{XSO}_{4} \cdot \mathrm{H}_{2} \mathrm{O}\right)$ to $\mathrm{S}^{2-}$ is least efficient. As reported for ADR lava at QFM-2 (Table 4), the release of large amounts of $\mathrm{SO}_{2}-\mathrm{H}_{2} \mathrm{O}$-rich gas accounts for an increase from $\sim 1500$ to $\sim 1600 \mathrm{ppm} \mathrm{S}^{2-}$ in the melt (Fig. 5a).

Because of the low capacity of silicate melts to transform and dissolve sulfate as $S^{2-}$ (Fig. 5 and Table 4), the integration of results from the lava erosion and volatile degassing simulations is restricted to physical-chemical lava and substrate parameters that would account for sulfide supersaturation at the lowest $\mathrm{S}^{2-}$ and SCSS values. As demonstrated by the erosion and assimilation simulations of sulfide-rich substrate (Fig, 4), such may be achieved at low eruption temperatures, relatively high flow rate per unit width $(\mathrm{Q}=800$ $\left.\mathrm{m}^{2} \cdot \mathrm{s}^{-1}\right)$, shallow sloped ground $\left(\alpha=0.1^{\circ}\right)$, and strongly to moderately consolidated substrate $\left(\mathrm{Q}=800 \mathrm{~m}^{2} \cdot \mathrm{s}^{-1}\right)$. In addition, only the degassing calculations for strongly reduced $\left(f \mathrm{O}_{2}=\mathrm{QFM}-4\right)$ lavas and anhydrous sulfate in the assimilant require consideration (Table 4; see simulation 1 for ADR and LDM, and simulation 8 for Y98). Nonetheless, sulfide supersaturation is hampered by $\mathrm{SO}_{2}$ degassing at the expense of $\mathrm{S}^{2-}$ in the melt prior to the intersection with the SCSS trajectory (Fig. 6a and Fig. 6b). The high-flux emplacement of low-temperature LDM lava over strongly consolidated substrate at shallow ground slope is exceptional in that a narrow window of sulfide segregation may be promoted by the low SCSS at low temperatures, as well as the delayed increase of $\mathrm{S}^{2-}$ that accounts for sulfide (super-) saturation prior to the extensive release of sulfur-rich gas. However, sulfide saturation would only be achieved at high flow distances, with sulfide liquid segregation only at near-cotectic proportions because of the shallow sloped $\mathrm{S}^{2-}$ and SCSS trajectories at intersection (Fig. 6b).

\section{Discussion}

\subsection{Model uncertainties}

Sulfur assimilation as a mineralization process for massive sulfides in martian maficultramafic volcanic systems is explored by detailed numerical simulations of turbulent 
flow and erosion of unconsolidated to strongly consolidated, either sulfide or sulfate-rich substrate. Thermodynamic simulations in the $\mathrm{C}-\mathrm{H}-\mathrm{O}-\mathrm{S}$ fluid system address the question of whether the interaction of reduced lavas $\left(f \mathrm{O}_{2}<<Q F M\right)$ with sedimentary sulfate serves as a feasible process for sulfide supersaturation. The interpretation of simulation results is hereafter re-examined against sources of errors arising from underlying modeling assumptions, and uncertainties introduced by the model input parameter estimates.

Mechanical and thermo-mechanical erosion and assimilation of bedrock by steady-state lava flows is controversially discussed. The interaction of high-temperature lavas with cold sedimentary substrate may not always immediately result in thermal erosion, but could account for an aphanitic contact zone (chilled margin) that counteracts thermal erosion. Nevertheless, field observations among komatiites suggest that at least convective hightemperature flows in the turbulent flow regime are capable to rapidly heat and melt such barriers by the passage of large volumes of hot lava (Huppert and Sparks, 1989; Hill et al., 1995; Greeley et al., 1998). A potentially more important source of error is mechanical erosion, which is herein assumed to be proportional to the shear stress that parallels the flow of lava (Sklar and Dietrich, 1998; Hurwitz et al., 2010). Alternative approaches consider the lava load pressure as the dominant factor that drives physical abrasion (Siewert and Ferlito, 2010). In addition, mechanical erodibility constants remain poorly constrained (Hurwitz et al., 2010, 2013). Small variations among weakly to strongly consolidated substrate can significantly influence the simulation results, in particular if low ground slopes are considered (see Fig. 4a, Fig. 4b and Fig. 4c).

The mass balance expressions for the substrate erosion and assimilation process (eq. (13) and eq. (14)) assume instantaneous mixing of sulfur from the mechanically and thermomechanically eroded substrate into turbulently flowing lava. However, such simplified processes likely do not hold true for high-flux flows that interact with strongly consolidated materials, potentially mobilizing and carrying centimetre- to meter-sized xenoliths over some distance prior to melting and dissolution in the lava (e.g., Jaeger et al., 2010; Hurwitz et al., 2010; Cataldo et al., 2015; Robertson et al., 2015). However, comparatively faster assimilation will occur during the erosion of porous and moderately consolidated substrate. In this case any fragments will be smaller, more easily dismembered by turbulent fluid sheer stress, and sulfur may thus be more rapidly liberated and assimilated by the flowing lava through thermal sulfate decomposition (Frost et al., 2006), or time-dependent melting and dissolution of sulfides (Robertson et al., 2015, 2016). Notably, pyrite, such as is the dominant sulfide species in the regolith breccias 
NWA 7533 and NWA 7034 (Lorand et al., 2015), may release sulfur at lower temperatures (i.e., incongruent melting to pyrrhotite at $>750{ }^{\circ} \mathrm{C}$; Toulmin and Barton, 1964) than silicate-oxide melting at $>1100{ }^{\circ} \mathrm{C}$. The same may hold true for sedimentary sulfates (e.g., thermal decomposition of hydronium-jarosite in the $\sim 600-900{ }^{\circ} \mathrm{C}$ range; Frost et al., 2006). The thermodynamic calculation of volatile degassing as function of sulfate assimilation in flowing lava required significant simplifications. Volatile-degassing was omitted for the simulation of reduced $\left(f \mathrm{O}_{2}<\mathrm{QFM}-2\right)$ and water-deficient $\left(<0.1 \mathrm{wt} \% \mathrm{H}_{2} \mathrm{O}\right)$ lava flows that interact with (dry) sulfide-rich substrate. Only limited proportions of the assimilated sulfur may be exsolved as gas species. This approximation is supported by the low sulfur volatilization rates in the low-pressure (0.01-1 bar) simulations for reduced and waterdeficient magmas in Gaillard et al. (2013). The negative effect of pressure on degassing also suggests that any sulfur loss would be lower at comparatively higher pressures in channelled lava flows; i.e., depth-averaged load pressures of $\sim 1-6$ bar calculated for $\sim 3300$ $\mathrm{kg} \cdot \mathrm{m}^{-3}$ lava density and flow thicknesses of $\sim 20-100 \mathrm{~m}$ (Fig. 3a). Nonetheless, it is clear that sulfur degassing will occur. Other known simplifications imply that our simulations must be considered as a semi-quantitative approach only. The chaotic movement of gas bubbles during the turbulent flow of lava would inevitably account for their infinitely fast equilibration at different pressure regimes. In addition, the employed model does not accounts for the unknown amounts of gas that can be released at the flow tops (i.e., closedsystem approximation).

Another source of uncertainty in the thermodynamic simulation of sulfate assimilation is the unknown effect of sulfate reduction $\left(\mathrm{S}^{6-} \rightarrow \mathrm{S}^{2-}\right.$; eq. (24)) and concomitant iron oxidation $\left(\mathrm{Fe}^{2+} \rightarrow \mathrm{Fe}^{3+}\right.$; eq. (25)) on the stability of ion-oxide phases. Our simulations indicate that this process accounts for the rapid oxidation of initially reduced $\left(f \mathrm{O}_{2} \leq \mathrm{QFM}\right.$ 2) silicate melts, at least up until high production rates of $\mathrm{SO}_{2}$-rich gas (Table 4 and Fig. 5c). However, it is plausible that the oxidation of $\mathrm{Fe}^{2+}$ to $\mathrm{Fe}^{3+}$ accounts for the precipitation of iron-oxides (e.g., ferric iron-rich spinel phases, such as magnetite). These phases can efficiently sequester $\mathrm{Fe}^{3+}$ from silicate melts, may counteract melt oxidation by sulfate assimilation, and could facilitate to the more efficient transformation of $\mathrm{SO}_{3}$ to $\mathrm{S}^{2-}$ than predicted in this study.

7.2. Favourable conditions for precious metal-rich sulfide genesis 
It has been suggested that near-surface sulfide enrichments on Mars could have formed by erosion and assimilation of sulfate-rich sedimentary materials by reduced high-temperature lava flows in the turbulent flow regime (Baumgartner et al., 2015). However, our thermodynamic simulations indicate that the feasibility of this process is limited, at least with respect to prolonged sulfide (batch) segregation. While the thermodynamic simulations comprise simplifications, it is likely that even strongly reduced lavas $\left(f \mathrm{O}_{2}\right.$ $<$ QFM-2) dissolve only low fractions of sulfate as $\mathrm{S}^{2-}$ prior to extreme $\mathrm{SO}_{2}$ degassing (Table 4 and Fig. 5). Such small increases are unlikely to result in prolonged sulfide immiscibility (Fig. 6), particularly if the low bulk sulfur concentrations of primitive shergottites (e.g., Y-980459 with <1500 ppm S; Table 2) are reasonable proxies for the source magmas.

The volatile degassing calculations (Table 4) suggest that narrow/windows of sulfide saturation by means of sulfate assimilation could occur if the sulfur concentrations at magma eruption are close to the SCSS ( 4000-5000 ppm S for Y98, and 2000-3000 ppm $\mathrm{S}$ for ADR and LDM; Fig. 4a, Fig. 4b and Fig. 4c). However, martian mantle-derived magmas may essentially emplace at sulfide undersaturated conditions (Baumgartner et al., 2017a, 2017b; Wang and Becker, 2017; among others). The martian mantle is considered to be rich in sulfur ( 400-2200 ppm S; Righter et al., 2009; Gaillard et al., 2013; Ding et al., 2015; Wang and Becker, 2017) with respect to the Earth ( 250 ppm S; McDonough and Sun, 1995). Sulfide saturation or insufficient dissolution of mantle sulfides can occur even if moderate sulfur concentrations in the mantle $(\sim 700 \mathrm{ppm} \mathrm{S})$, high SCSS in the derived melts ( 3500-4000 ppm S) and <20\% mantle melting is considered (Ding et al., 2014, 2015). Gaps between sulfur and the SCSS may be promoted by volatile release and the increasing solubility of sulfur during magma ascent and decompression (O'Neill and Mavrogenes, 2002; Righter et al., 2009; Gaillard et al., 2013; Ding et al., 2014, 2015). Above all, increases of $\mathrm{S}^{2-}$ in the lava by means of hydrous sulfate assimilation may be negligible (Fig. 5 and Table 4). Conditions favoring the formation and preservation of dry sulfates may have rarely been met at Mars' near-surface during wet periods in the Noachian and early Hesperian epochs (Bibring et al., 2006; King and McLennan, 2010; Gaillard et al., 2013; Ehlmann and Edwards, 2014).

In spite of uncertainties in the erosion and assimilation model for sulfide-rich regolith materials, the simulation results (Fig. 4a to Fig. 4c) suggest that this scenario could have been an efficient trigger for sulfide mineralization events. Our study also allows inferences concerning their modes of occurrences with respect to the diverse array of potential lava, 
substrate and ambient parameters. Irrespective of lava type and eruption temperature, sulfide batch segregation would be promoted by high ground slopes (Fig. 4a, Fig. 4b and Fig. 4c), at which mechanical erosion and the flux of sulfur into the lava is most efficient. Increased erosion at high ground slopes $\left(>1^{\circ}\right)$ minimizes the uncertainty introduced by the mechanical erodibility constants. Batch segregation of sulfide liquids would be promoted within $\sim 200 \mathrm{~km}$ of low-temperature flows (Fig. 4a, Fig. 4b and Fig. 4c), provided that the substrate is rich in sulfides (e.g., $1 \mathrm{wt} \% \mathrm{~S}$ ) and that sulfur is readily released from the assimilant. Lower sulfur concentrations in the magma and the assimilant would shift sulfide immiscibility towards higher flow distances, but any differences would be smaller on steep surfaces, where mechanical erosion and the flux of sulfur into the lava is high. Noteworthy, as opposed to emplacement over shallow sloped ground $\left(<1^{\circ}\right)$, rapid assimilation of sulfur would account for higher degrees of sulfide/ supersaturation and sulfide liquid segregation.

\subsection{Enrichment of $\mathrm{Ni}, \mathrm{Cu}$ and PGE}

An important question that requires evaluation is whether massive sulfide mineralization in martian lava flows would be similarly enriched in $\mathrm{Ni}, \mathrm{Cu}$ and the PGE with respect to their komatiite-hosted equivalents on the Earth. The importance of the siderophile-chalcophile metal inventory of mantle sources and derived melts was recently discussed in Baumgartner et al. (2015). As far as the PGE are concerned, the mantle concentrations appear to be at broadly comparable, yet slightly lower concentrations on Mars than on the Earth (0.009 and $0.007 \times$ CI-chondrite, respectively; Day et al., 2016 and references therein). These signatures likely reflect pressure-dependent core-mantle equilibration in primordial magma oceans, possibly in combination with influences by the accretion of a late chondritic veneer (Brandon et al., 2012; Righter et al., 2015). The low $\mathrm{Ni}$ and $\mathrm{Cu}$ concentrations in shergottites suggest only $\sim 400 \mathrm{ppm} \mathrm{Ni}$ and $\sim 6 \mathrm{ppm} \mathrm{Cu}$ in the primitive mantle (Dreibus and Wänke, 1985; Righter and Chabot, 2011), whereas Earth's primitive mantle was estimated to exhibit higher abundances of $\sim 1960 \mathrm{ppm} \mathrm{Ni}$ and $\sim 30 \mathrm{ppm} \mathrm{Cu}$ (McDonough and Sun, 1995). These differences comply with planetary accretion and differentiation models; i.e., core-mantle differentiation at lower pressures on Mars ( 15 GPa) than on the Earth ( 30 GPa); Righter and Chabot (2011); Righter et al. (2015); Yang et al. (2015). 
In line with these considerations, martian high-degree mantle melts, such as those parental to the Amazonian Y-980459 shergottite (Y98) and the Hesperian Adirondack-class basalts (ADR) simulated in this study, may only contain $\sim 200-250 \mathrm{ppm} \mathrm{Ni}$, which is significantly below the estimates of $\sim 700-1000$ ppm for komatiites and ferropicrites (Baumgartner et al., 2015 and references therein). The concentrations of Ni may be lower in Amazonian lowdegree mantle melts (LDM). Nickel in the mantles of both planets is predominately hosted by olivine through substitution with $\mathrm{Mg}$ and $\mathrm{Fe}$, thus accounting for increases in $\mathrm{Ni}$ in mantle melts that parallel higher degrees of partial melting. Yet, this relationship may be less pronounced on Mars. Indeed, the iron-rich nature of the mantle implies that iron-rich olivine would participate earlier in mantle melting processes than on the Earth (Bertka and Holloway, 1994a, 1994b; Baratoux et al., 2011; Collinet et al., 2015). A positive relationship with the degree of melting may hold true for $\mathrm{Cu}$ and PGE. These elements may be hosted by sulfides, which will be more easily dissolved into the melts at higher degrees of mantle melting (Righter et al., 2015; Lorand and Luguet, 2016; Baumgartner et al., 2017b).

Mineralization events for Ni-rich sulfides would be promoted by the early attainment of sulfide supersaturation during cooling and fractionation of lava. Otherwise, Ni (and part of the compatible PGE Os, Ir and Ru) would be sequestered by crystallizing olivine (and spinel phases) prior to collection by immiscible sulfides (Baumgartner et al., 2015). Of major importance for the upgrade of precious metals could be the dynamic emplacement of high-flux lava flows. The enrichments of $\mathrm{Ni}, \mathrm{Cu}$ and the PGE in komatiite-hosted sulfide deposits is testimony of the prolonged equilibration between sulfide liquids and new magma pulses along the flows (i.e., R-factor $=$ effective sulfide/silicate ratio; Campbell and Naldrett, 1979; Lesher and Campbell, 1993). This process accounts for the continuous collection of siderophile-chalcophile elements according to their sulfide-silicate partitioning coefficients ( $\mathrm{D}^{\text {metal-silicate }} \sim 10^{3}$ for $\mathrm{Ni}$ and $\mathrm{Cu}$, and $\sim 10^{4-} 10^{5}$ for the PGE); Patten et al. (2013); Mungall and Brenan (2014); Brenan et al. (2016). Similar processes can be ascertained for voluminous high-flux lava flows on Mars, in which the deficiencies in $\mathrm{Ni}$ and $\mathrm{Cu}$ relative to komatiites and ferropicrites may be partially compensated by comparatively higher R-factors.

7.4. Genesis of sulfide mineralization - where and when? 
The analysis of the simulation results allows for inferences concerning the potential localization of large sulfide occurrences at Mars' near-surface. Mineralization events may have occurred when fertile mantle melts dynamically interacted as high-flux lava flows with sulfidic materials. Our numerical simulations suggest that sulfide batch segregation as function of flow distance is in decreasing order promoted by high ground slope, low substrate consolidation, as well as low lava temperatures and flow rates. The limited accessibility of surface geology for direct investigation hampers the search for volcanic environments that meet these criteria, and requires translation of this understanding into remotely identifiable targeting elements. However, a major obstacle is that sulfides lack distinctive features in the near-visible to thermal emission spectrum. This prohibits the survey of Mars' for low-viscosity lava flows that interleaved with sulfide-rich substrates.

Although these difficulties hamper detailed examinations at the scale of individual lava flows, potential candidates for large sulfide endowments may be discussed at the regional scale. The relatively shallow sloped flanks of Alba Mons (Tharsis province) and Tyrrhena Patera (Circum-Hellas volcanic province) may be testimony of high-temperature and fluid mafic-ultramafic lava expulsions. Indeed, lava tubes and channels are major flow types at the flanks of both volcanoes (Cattermole, 1990; Ivanov and Head, 2006; Williams et al., 2009). They inundate the local topography or incise into the volcanic bedrocks. Similar channels occur at the flanks of other large montes and low shield expulsions at Tharsis, Elysium and the Circum-Hellas region (Fig. 1a and Fig. 1b; c.f., Williams et al., 2005; Bleacher et al., 2007; Vaucher et al., 2009; Lopez et al., 2012; Crown and Ramsey, 2016; among others). They vanish at peripheral regions of the Montes, or can extend for hundreds of kilometres over the volcanic plateaus (e.g., Garry et al., 2007). However, none of these surficial flows bear evidence for their interaction with (sulfidic) regoliths or sedimentary materials, but apparently incised into basaltic bedrocks or pyroclastic deposits. More detailed clues on potentially mineralized volcanic suits may be given by the large canyon systems Noctis Labyrinthus and Valles Marineris, as well as the large (up to 1000+ km) Hesperian outflow channels in vicinity to the Tharsis and Elysium provinces (e.g., Kasei Valles, Maja Valles, Manga Valles, Hrad Valles, and others), all of which incised into heavily brecciated Noachian crust. The formation of the latter remains controversially discussed, in particular with respect to the question of whether enormous volumes of flowing lava or water have been the main erosion agents (Leverington, 2011; Leone, 2014). If erosion by low-viscosity lava was a key mechanism, it is possible that some flows interleaved with sulfide-rich materials, such as (sulfide-bearing) regolith or intercalated 
sedimentary materials that cover Noachian terrains (Hartmann and Barlow, 2006). Similar processes may have post-dated channel formation. As similar to Valles Marineris, most outflow channels are filled by interleaving successions of volcanic flood lavas and fluvioglacial sediments above heavily brecciated Noachian basements (McEwen et al., 1999; Mangold et al., 2008; Chapman et al., 2010; Keske et al., 2015; Rice and Baker, 2015). The slopes of these depressions are usually well above $0.1^{\circ}$, as required for sulfide mineralization events through efficient erosion/assimilation of (sulfidic) substrates by turbulent lava flooding (Fig. 4a, Fig. 4b and Fig. 4c).

\section{Conclusions}

Potential mineralization events for komatiite-type massive sulfides in martian mantlederived igneous provinces were examined by numerical simulation of turbulent lava emplacement and associated erosion/assimilation of variably consolidated sulfur-rich materials that cover Mars' surface. The integration of the simulation results with the spatial distribution of sulfur-rich sedimentary materials and the known physical-chemical characteristics (i.e., composition, temperature, redox condition, and sulfur concentration) of mantle-derived igneous activity lead to the following conclusions:

- The numerical simulations of mechanical and thermo-mechanical erosion by physically and chemically diverse lavas in the turbulent flow regime confirm their capability to assimilate sulfur from sulfide- or sulfate-bearing sedimentary materials. Examination of sulfide supersaturation by erosion and assimilation of sulfide-rich regolith provides clues regarding the parameters that control the rapid assimilation of sulfur until sulfide supersaturation. Sulfide batch segregation is in decreasing order controlled by ground slope, substrate consolidation, lava temperature and flow rate.

- Provided that the substrates contain significant proportions of (sedimentary or hydrothermal) sulfides, steep ground slopes $\left(>1^{\circ}\right.$ ) would always account for high erosion rates, and if the eroded substrate is readily assimilated in the flow, sulfide supersaturation proximal to the flow sources; i.e., $<400 \mathrm{~km}$ for high-temperature flows $\left(>1400{ }^{\circ} \mathrm{C}\right)$, and $<200 \mathrm{~km}$ for Hesperian to Amazonian low-temperature flows $(<1350$ $\left.{ }^{\circ} \mathrm{C}\right)$. Sulfide batch segregation at comparable flow distances over flat terrains $\left(<1^{\circ}\right)$ may be promoted by unconsolidated substrates.

- Thermodynamic calculations concerning the influence of (hydrous) sulfate assimilation on redox conditions and the stability of sulfur-rich volatile species 
elucidate the limited viability of such a process to account for sulfide supersaturation and massive sulfide genesis. Martian mafic-ultramafic magmas may only assimilate and reduce small amounts of sulfate $\left(\mathrm{S}^{6+}\right)$ to sulfide $\left(\mathrm{S}^{2-}\right)$ prior to rapid melt oxidation and the production of $\mathrm{SO}_{2}$. Hence, sulfate assimilation appears to be incapable of driving prolonged sulfide batch segregation in initially reduced $\left(f \mathrm{O}_{2}<<Q F M\right)$ and sulfide undersaturated mantle melts.

- The enrichment of terrestrial komatiite-hosted massive sulfides in siderophilechalcophile elements (i.e., $\mathrm{Ni}, \mathrm{Cu}$ and the PGE) led us to consider the question of whether similar precious-metal fertilities can be expected if massive sulfides have formed on Mars. Despite lower Ni and $\mathrm{Cu}$ concentrations in martian mantle reservoirs and derived melts relative to the Earth, the prolonged equilibration between immiscible sulfide liquids and new pulses of lava along the flows could partially outweigh the $\mathrm{Ni}$ and $\mathrm{Cu}$ deficiencies in martian magmas.

This study indicates that large orthomagmatic sulfide endowments on Mars could have formed if (channelled) erosive mafic-ultramafic lava flows spatially interleaved with sulfide-bearing bedrocks at steep slopes. This conclusion should be taken into consideration by future studies concerníng sulfide deposit genesis in martian igneous systems. The likely locations of massive orthomagmatic sulfide deposits on Mars remain uncertain. Nonetheless, promising candidates could be the large canyon systems Noctis Labyrinthus and Valles Marineris, as well as the Hesperian channel systems of the Southern highlands, which were periodically draped by mafic-ultramafic lava flows.

\section{References}

Agee C.B., Wilson, N.V., McCubbin, F.M., et al. 2013. Unique Meteorite from Early Amazonian Mars: Water-Rich Basaltic Breccia Northwest Africa 7034. Science 339, 780785.

Arndt, N.T., Jenner, G.A., 1986. Crustally contaminated komatiites and basalts from Kambalda, Western Australia. Chem. Geol. 56, 229-255.

Arndt, N.Y., Lesher, C.M., Czamaske, G.K., 2005. Mantle-derived magmas and magmatic Ni-Cu-(PGE) deposits. Econ. Geol. 100th Anniv. Vol., pp. 5-23.

Balta, B.J., McSween, H.Y., 2013. Water and the composition of martian magmas. Geology 41, 1115-1118. 
Balta, B.J., Sanborn, M.E., Udry, A., Wadhwa, M., McSween, H.Y., 2015. Petrology and trace element geochemistry of Tissint, the newest shergottite fall. Meteorit. Planet. Sci., 50, 63-85.

Baratoux, D., Toplis, M.J., Monnereau, M., 2013. The petrological expression of early Mars volcanism. J. Geophys. Res. Planets 118, E1.

Baratoux, D., Toplis, M.J., Monnereau, M., Gasnault, O., 2011. Thermal history of Mars inferred from orbital geochemistry of volcanic provinces. Science 472, 338-341.

Barnes, S.J., Fiorentini, M.L., 2012. Komatiite magmas and nickel sulfide deposits: a comparison of variably endowed Archean terranes. Econ. Geol. 107, 755-780.

Baumgartner, R.J., Fiorentini, M.L., Baratoux, D., Micklethwaite, S., Sener, A.K., Lorand, J.P. and McCuaig, T.C., 2015. Magmatic controls on the genesis of Ni-Cu $\pm(P G E)$ sulfide mineralisation on Mars. Ore Geol. Rev., 65, 400-412.

Baumgartner, R.J., Fiorentini, M.L., Ferrière, L., Locmelis, M., Tomkins, A., Sener, K.A., 2017a. The variability of ruthenium in chromite from chassignite and olivine-phyric shergottite meteorites: new insights into the behavior of PGE and sulfur in martian magmatic systems. Meteorit. Planet. Sci. 52, 333-350.

Baumgartner, R.J., Fiorentini, M.L., Lorand, J.P., Baratoux, D., Zaccarini, F., Ferrière, L., Prašek, M.K., Sener, A.K., 2017b. The role of sulfides in the fractionation of highly siderophile and chalcophile elements during the formation of martian shergottite meteorites. Geochim. Cosmochim. Acta, doi.org/10.1016/j.gca.2017.04.011.

Bertka, C.M., Holloway, J.R., 1994a. Anhydrous partial melting of an iron-rich mantle I: subsolidus phase assemblages and partial melting phase relations at 10 to $30 \mathrm{kbar}$. Contrib. Mineral. Petrol. 145, 313-322.

Bertka, C.M., Holloway, J.R., 1994b. Anhydrous partial melting of an iron-rich mantle II: primary melt compositions at 15 kbar. Contrib. Mineral. Petrol. 115, 323-338.

Bibring, J.P., Langevin, Y., Mustard, J., Poulet, F., Arvidson, R.E., Gendrin, A., Gondet, B., Mangold, N., Pinet, P., Forget, F., 2006. Global mineralogical and aqueous Mars history derived from OMEGA/Mars Express data. Science 312, 400-404.

Bleacher, J.E., Greeley, R., Williams, D.A., Cave, S.R., Neukum, G., 2007. Trends in effusive style at the Tharsis Montes, Mars, and implications for the development of the Tharsis province. J. Geophys. Res. 112, E09005.

Brandon, A.D., Puchtel, I.S., Walker, R.J., Day, J.M.D., Irving, A.J., Taylor, L.A., 2012. Evolution of the martian mantle inferred from the 187Re-187Os isotope and highly 
siderophile element abundance systematics of shergottite meteorites. Geochim. Cosmochim. Acta 76, 206-235.

Brenan, J.M., Bennett, N.R., Zajacz, Z., 2016. Experimental Results on Fractionation of the Highly Siderophile Elements (HSE) at Variable Pressures and Temperatures during Planetary and Magmatic Differentiation. Rev. Mineral. Geochem. 81, 1-88.

Burgisser, A., Alletti, M., Scaillet, B., 2015. Simulating the behaviour of volatiles belonging to the C-O-H-S system in silicate melts under magmatic conditions with the software d-compress. Comp. Geosci. 79, 1-14.

Burgisser, A., Scaillet, B., 2007. Redox evolution of degassing magma rising to the surface. Nature 445, 194-197.

Burns, R.G., Fisher, D.S., 1990. Evolution of sulfide mineralization on Mars. J. Geophys. Res. 95, 14169-14173.

Campbell, I.H., Naldrett, A.J., 1979. The influence of silicate:sulfide ratios on the geochemistry of magmatic sulfides. Econ. Geol. 74, 1503-1505.

Cannon, K.M., Mustard, J.F., Agee, C.B., 2015. Evidence for a widespread basaltic breccia component in the martian low-albedo regions from the reflectance spectrum of Northwest Africa 7034. Icarus 252, 150-153.

Cataldo, V., Williams, D.A., Dundas, C.M., Keszthelyi, L.P., 2015. Limited role for thermal erosion by turbulent lava in proximal Athabasca Valles, Mars. J. Geophys. Res. 120, E11.

Cattermole, P., 1990. Volcanic flow development at Alba Patera, Mars. Icarus 83, 453-493. Chapman, M.G., Neukum, G., Dumke, A., Michael, G., Van Gassel, S., Kneissl, T., Zuschneid, W., Hauber, E., Mangold, N., 2010. Amazonian geologic history of the Echus Chasma and Kasei Valles system on Mars: New data and interpretations. Earth Planet. Sci. Lett. 294, 238-255.

Chevrier, V., Lorand, J.P., Sautter, V. 2011. Sulfide petrology of four nakhlites: Northwest Africa 817, Northwest Africa 998, Nakhla, and Governador Valadares. Meteorit. Planet. Sci. $41,1-17$.

Clifford, S.M., 1993. A model for the hydrologic and climatic behaviour of water on Mars. J. Geophys. Res. 98, 10973-11016.

Collinet, M., Medard, E., Charlier, B., Vander Auwera, J., Grove, T.L., 2015. Melting of the primitive martian mantle at $0.5-2.2 \mathrm{GPa}$ and the origin of basalts and alkaline rocks on Mars. Earth. Planet. Sci. Lett. 427, 83-94. 
Crown, D.A., Ramsey, M.S., 2016. Morphologic and thermophysical characteristics of lava flows southwest of Arsia Mons, Mars. J. Volcanol. Geotherm. Res., doi:10.1016/j.jvolgeores.2016.07.008.

Day, J.M.D., Brandon, A.D., Walker, R.J., 2016. Highly Siderophile Elements in Earth, Mars, the Moon, and Asteroids. Rev. Mineral. Geochem. 81, 161-238.

Dehouck, E., Chevrier, V., Gaudin, A., Mangold, N., Mathé, P.E., Rochette, P., 2010. Evaluating the role of sulfide-weathering in the formation of sulfates or carbonates on Mars. Geochim. Cosmochim. Acta 90, 47-63.

Ding, S., Dasgupta R., Lee, C.T.A., Wadhwa, M., 2015. New bulk sulfur measurements of martian meteorites and modeling the fate of sulfur during melting and crystallization Implications for sulfur transfer from martian mantle to crust-atmosphere system. Earth Planet. Sci. Lett. 409, 157-167.

Ding, S., Dasgupta, R., Tsuno, K., 2014. Sulphur concentration of martian basalts at sulphide saturation at high pressures and temperatures - Implications for deep sulphur cycle on Mars. Geochim. Cosmochim. Acta 131,227-246.

Dreibus, G., Wänke, H., 1985. Mars, a volatile-rich planet. Meteoritics 20, 367-381.

Drouet, C., Pass, K.L., Baron, D., Draucker, S., Navrotsky, A., 2004. Thermochemistry of jarosite-alunite and natrojarosite - natroalunite solid solutions, Geochim. Cosmochim. Acta 68, 2197-2205.

Dundas, C.M., Keszthelyi, L.P., 2014. Emplacement and erosive effects of lava in south Kasei Valles, Mars. J. Volcan. Geotherm. Res. 282, 92-102.

Ehlmann, B.L., Edwards, C.S., 2014. Mineralogy of the martian Surface. Annu. Rev. Earth Planet. Sci. 42, 219-315.

Filiberto, J., 2008. Similarities between the shergottites and terrestrial ferropicrites. Icarus $197,52-59$.

Filiberto, J., Baratoux, D., Beaty, D., Breuer, D., Farcy, B.J., Grott, M., Jones, J.H., Kiefer, W.S., Mane, P., McCubbin, F.M., Schwenzer, S.P., 2016. A review of volatiles in the martian interior. Meteorit Planet. Sci., doi:10.1111/maps.12680.

Filiberto, J., Dasgupta, R., 2015. Constraints on the depth and thermal vigor of melting in the martian mantle. J. Geophys. Res. 120, E1.

Filiberto, J., Treiman, A.H., Le, L., 2008. Crystallization experiments on a Gusev Adirondack basalt composition. Meteorit. Planet. Sci. 43, 1137-1146. 
Fortin, M.A., Riddle, J., Desjardins-Langlais, Y., Baker, D.R., 2015. The effect of water on the sulfur concentration at sulfide saturation (SCSS) in natural melts. Geochim. Cosmochim. Acta 160, 100-116.

Franz H.B., Kim S.T., Farquhar J., Day J.M.D., Economos R.C., McKeegan K.D., Schmitt A.K., Irving A.J., Hoek J., Dottin J., 2014. Isotopic links between atmospheric chemistry and the deep sulfur cycle on Mars. Nat. Geosci. 508, 364-368.

Frost, R. L., Wills, R. A., Kloprogge, J. T., et al., 2006. Thermal decomposition of hydronium jarosite $\left(\mathrm{H}_{3} \mathrm{O}\right) \mathrm{Fe}_{3}\left(\mathrm{SO}_{4}\right)_{2}(\mathrm{OH})_{6}$. Therm. Anal. Calorim. 83, 213-218.

Gaillard, F., Michalski, J., Berger, G., McLennan, S.M., Scaillet, B., 2013. Geochemical reservoirs and timing of sulfur cycling on Mars. Space Sci. Rev. 174, 251-300.

Garry, W.B., Zimbelman, J.R., Gregg, T.K.P, 2007. Morphology and emplacement of a long channeled lava flow near Ascraeus Mons Volcano, Mars. J. Geophys. Res. 112, E8.

Gavin, P., Chevrier, V., Ninagawa, K., Gucsik, A., Hasegawa, S., 2010. Experimental investigation into the effects of meteoritic impacts on the spectral properties of phyllosilicates on Mars. J. Geophys. Res. (Planets) 118, 65-80.

Ghiorso, M.S., Sack, R.O., 1995. Chemical mass transfer in magmatic processes. IV. A revised and internally consistent thermodynamic model for the interpolation and extrapolation of liquid-solid equilibria in magmatic systems at elevated temperatures and pressures. Contrib. Mineral. Petrol. 119, 197-212.

Giordano, D., Russell, J.K., Dingwell, D.B., 2008. Viscosity of magmatic liquids: A model. Earth Planet. Sci. Lett., 271, 123-134.

Goodrich C.A., Herd C.D.K., Taylor, L.A., 2003. Spinels and oxygen fugacity in olivinephyric and lherzolitic shergottites. Meteorit. Planet. Sci. 38, 1773-1792.

Greeley, R., Fagents, S.A., Harris, R.S., Kadel, S.D., Williams, D.A., Guest, J.E., 1998. Erosion by flowing lava: Field evidence. J. Geophys. Res. (Solid Earth) 103, B11.

Greshake A., Fritz J., Stöffler, D., 2004. Petrology and shock metamorphism of the olivine-phyric shergottite Yamato 980459: evidence for a two-stage cooling and a singlestage ejection history. Geochim. Cosmochim. Acta 68, 2359-2377.

Grott, M., Baratoux, D., Hauber, E., Sautter, V., Mustard, J., Gasnault, O., Ruff, S.W., Karato, S.I., Debaille, V., Knapmeyer, M., Sohl, F., Van Hoolst, T., Breuer, D., Morschhauser, A. and Toplis, M.J., 2013. Long-term evolution of the martian crust-mantle system. Space Sci. Rev., 174, 49-111. 
Grotzinger, J.P., Sumner, D.Y., Kah, L.C., et al., 2014. A habitable fluvio-lacustrine environment at Yellowknife Bay, Gale crater, Mars. Science 343, doi:10.1126/science.1242777.

Hartmann, W.K., Barlow, N.G., 2006. Nature of the Martian uplands: Effect on Martian meteorite age distribution and secondary cratering. Meteorit. Planet. Sci. 41, 1453-1467.

Herd C.D.K., Borg L.E., Jones J.H., Papike J.J., 2002. Oxygen fugacity and geochemical variations in the martian basalts: Implications for martian basalt petrogenesis and the oxidation state of the upper mantle of Mars. Geochim. Cosmochim. Acta 66, 2025-2036.

Hill, R.E.T., Barnes, S.J., Gole, M.J., Dowling, S.E., 1995. The volcanology of komatiites as deduced from field relations in the Norseman-Wiluna greenstone belt, Western Australia. Lithos 34, 159-188.

Hopper, J.P., Leverington, D.W., 2014. Formation of Hrad Vallis (Mars) by low viscosity lava flows. Geomorphology 207, 96-113.

Hulme, G., 1973. Turbulent lava flow and the formation of lunar sinuous rilles. Mod. Geol. 4, 107-117.

Humayun, M., Nemchin, A., Zanda, B., Hewins, R.H., Grange, M., Kennedy, A., Lorand, J.P., Göpel, C., Fieni, C., Pont, S., Deldicque, D., 2013. Origin and age of the earliest martian crust from meteorite NWA 7533. Nature 503, 513-516.

Huppert, H.E., Sparks, R.S.J., 1985. Komatiites, I, Eruption and flow. J. Petrol. 26, 694725.

Huppert, H.E., Sparks, R.S.J., 1989. Chilled margins in igneous rocks. Earth Planet. Sci. Lett. 92, 397-405.

Hurwitz, D.M., Fassett, C.I., Head, J.W., Wilson, L., 2010. Formation of an eroded lava channel within an Elysium Planitia impact crater: distinguishing between a mechanical and thermal origin. Icarus 210, 626-634.

Hurwitz, D.M., Head, J.W., Byrne, P.K., Xiao, Z., Solomon, S.C., Zuber, M.T., Smith, D.E., Neumann, G.A., 2013. Investigating the origin of candidate lava channels on Mercury with MESSENGER data: Theory and observations. J. Geophys. Res. (Planets) $118,471-486$.

Iacono-Marziano, G., Morizet, Y., Le Trong, E., Gaillard, F., 2012. New experimental data and semi-empirical parameterization of $\mathrm{H} 2 \mathrm{O}-\mathrm{CO} 2$ solubility in mafic melts. Geochim. Cosmochim. Acta 97, 1-23. 
Iacovinio, K., 2015. Linking subsurface to surface degassing at active volcanoes: A thermodynamic model with applications to Erebus volcano. Earth Planet. Sci. Lett. 431, 59-74.

Ivanov, M.A., Head, J.W., 2006. Alba Patera, Mars: Topography, structure, and evolution of a unique late Hesperian-early Amazonian shield volcano. J. Geophys. Res. 111, E09003.

Jaeger, W.L., Keszthelyi, L.P., Skinner, J.A., Milazzo, M.P., McEwen, A.S., Titus, T.N., Rosiek, M.R., Galuszka, D.M., Howington-Kraus, E., Kirk, R.L., The HiRISE Team, 2010. Emplacement of the youngest flood lava on Mars: a short, turbulent story. Tcarus 205, 230243.

Jugo, P.J., Wilke, M., Botcharnikov, R.E., 2010. Sulfur K-edge XANES analysis of natural and synthetic basaltic glasses: implications for $\mathrm{S}$ speciation and $\mathrm{S}$ content as function of oxygen fugacity. Geochim. Cosmochim. Acta 74, 5926-5938.

Kakaç, S., Shah, R.K., Aung, W., 1987. Handbook of single-phase convective heat transfer. John Wiley, New York, 1987.

Keske, A.L., Hamilton, C.W., McEwen, A.S., Daubar, I.J., 2015. Episodes of fluvial and volcanic activity in Mangala Valles, Mars. Icarus 245, 333-347.

King, P.L., McLennan, S.M., 2010. Sulfur on Mars. Elements 6, 107-112.

Kress V.C., Carmichael, I.S.E, 1991. The compressibility of silicate liquids containing $\mathrm{Fe}_{2} \mathrm{O}_{3}$ and the effect of composition, temperature, oxygen fugacity and pressure on their redox states. Contrib. Mineral. Petrol. 108, 82-92.

Lange, R.A., Navrotsky, A., 1992. Heat capacities of $\mathrm{Fe}_{2} \mathrm{O}_{3}$-bearing silicate liquids. Contrib. Mineral. Petrol. 110, 311-320.

Lange, R.L., Carmichael, S.E., 1987. Thermodynamic properties of silicate liquids with emphasis on density, thermal expansion and compressibility. Rev. Min. Geochem. 24, 2564.

Leask, H.J., Wilson, L., Mitchell, K.L., 2007. Formation of Mangala Valles outflow channel, Mars: morphological development and water discharge and duration estimates. J. Geophys. Res. 112, E08003.

Lentz, R.C.F., McCoy, T.J., Collins, L.E., Corrigan, C.M., Benedix, G.K., Taylor, G.J. and Harvey, R.P., 2011. Theo's Flow, Ontario, Canada: a terrestrial analog for the martian nakhlite meteorites. Geol. Soc. Am. Spec. Pap. 483, 263-277.

Leone, G., 2014. A network of lava tubes as the origin of Labyrinthus Noctis and Valles Marineris on Mars. J. Volcan. Geotherm. Res. 277, 1-8. 
Lesher, C. M., Campbell, I. H., 1993. Geochemical and Fluid Dynamic Modelling of Compositional Variations in Archean Komatiite-Hosted Nickel Sulfide Ores in Western Australia. Econ. Geol. 88, 804-816.

Lesher, C.M., Groves, D.I., 1986. Controls on the formation of komatiite associated nickelcopper sulfide deposits. In: Genkin, A.D., Naldrett, A.J., Ridge, J.D., Sillitoe, R.H., Vokes, F.M. (eds.) Geology and metallogeny of copper deposits. Springer-Verlag, Heidelberg, pp. 43-62.

Leverington, D.W., 2004. Volcanic rilles, streamlined islands, and the origin of outflow channels on Mars. J. Geophys. Res. (Planets), 109, E10.

Leverington, D.W., 2007. Was the Mangala Valles system incised by volcanic flows? J. Geophys. Res. 112, E11005.

Leverington, D.W., 2009. Reconciling channel formation mechanisms with the nature of elevated outflow systems at Ophir and Aurorae Plana, Mars. J. Geophys. Res. 114, E10005.

Leverington, D.W., 2011. A volcanic origin for the outflow channels of Mars: key evidence and major implications. Geomorphology 132, 51-75.

Lopez, T., Antoine R., Baratoux, D., Rabinowicz, M., Kurita, K., 2012. Thermal anomalies on pit craters and sinuous rilles of Arsia Mons: Possible signatures of atmospheric gas circulation in the volcano. J. Geophys. Res. (Planets) 117, E9.

Lorand, J.P., Chevrier, V., Sautter, Y., 2005. Sulfide mineralogy and redox conditions in some shergottites. Meteorit. Planet. Sci. 40, 1257-1272.

Lorand, J.P., Hewins, R.H., Remusat, L., Zanda, B., Pont, S., Leroux, H., Marinova, M., Jacob, D., Humayun, M., Nemchin A., Grange, M., Kennedy, A., Göpel, C., 2015. Nickeliferous pyrite tracks pervasive hydrothermal alteration in martian regolith breccia: A study in NWA 7533. Meteorit. Planet. Sci. 50, 2099-2120.

Lorand, J.P., Luguet, A., 2016. Chalcophile and Siderophile Elements in Mantle Rocks: Trace Elements Controlled By Trace Minerals. Rev. Mineral. Geochem. 81, 441-481.

Manga, M., Castro, J., Cashman, K.V., Loewenberg, M., 1998. Rheology of bubblebearing magmas. J. Volcanol. Geotherm. Res. 87, 15-28.

Mangold, N., Ansan, V., Masson, P., Quantin, C., Neukum, G., 2008. Geomorphic study of fluvial landforms on the northern Valles Marineris plateau, Mars. J. Geophys. Res. 113, E08009. 
Mangold, N., Thompson, L.M., Forni, O., et al., 2016. Composition of conglomerates analyzed by the Curiosity rover: Implications for Gale Crater crust and sediment sources, J. Geophys. Res. (Planets) 121, doi:10.1002/2015JE004977.

Massol, H., Jaupart, C., 1999. The generation of gas overpressure in volcanic eruptions. Earth Planet. Sci. Lett. 166, 57-70.

McDonough, W.F., Sun, S., 1995. The composition of the Earth. Chem. Geol. 120, 223254.

McEwen, A.S., Malin, M.C., Carr, M.H., Hartmann, W.K., 1999. Voluminous volcanism on early Mars revealed in Valles Marineris. Nature 397, 584-586.

McKay, G., Le, L., Schwandt, C., Mikouchi, T., Koizumi, E., Jones, J., 2004. Yamato980459: The most primitive shergottite? Lunar Planet. Sci. Conf. 35. CD-ROM (abs. \#2154).

Rice J. W., Baker V. R., 2015. New observations of martian outflow channel flood deposits. Lunar Planet. Sci. Conf. 46. CD-ROM (abs. \#2979).

McLennan S.M., Anderson, R.B., Bell, J.F., et al., 2014. Elemental Geochemistry of Sedimentary Rocks at Yellowknife Bay, Gale Crater, Mars. Science 343, doi:10.1126/science. 1244734

McSween, H.Y., Ruff, S.W., Morris, R.V., et al., 2008. Mineralogy of volcanic rocks in Gusev Crater, Mars: reconciling Mössbauer, Alpha Particle X-Ray Spectrometer, and Miniature Thermal Emission Spectrometer spectra. J. Geophys. Res. 113, E06S04.

McSween, H.Y., Taylor, J.G., Wyatt, M.B., 2009. Elemental composition of the martian crust. Science $324,736$.

Milton, D.J., 1973. Water and processes of degradation in the martian landscape. J. Geophys. Res. 78, 4037-4047.

Monders, A.G., Medard, E., Grove T.L., 2007. Phase equilibrium investigations of the Adirondack class basalts from the Gusev plains, Gusev crater, Mars. Meteorit. Planet. Sci. 42, 131-148.

Mungall, J.E., Brenan, J.M., 2014. Partitioning of platinum-group elements and $\mathrm{Au}$ between sulphide liquid and basalt and the origins of mantle-crust fractionation of the chalcophile elements. Geochim. Cosmochim. Acta 125, 265-289.

Mungall, J.E., Brenan, J.M., Godel, B., Barnes, S.J., Gaillard, F., 2015. Transport of metals and sulfur in magmas by flotation of sulfide melt on vapour bubbles. Nat. Geosci. 8, 216219. 
Musselwhite, D.S., Dalton, H.A., Kiefer, W.S., Treiman A.H., 2006. Experimental petrology of the basaltic shergottite Yamato-980459: implications for the thermal structure of the martian mantle. Meteorit. Planet. Sci. 41, 1271-1290.

O’Neill, H.S.C., Mavrogenes, J., 2002. The sulfide saturation capacity and the sulfur content at sulfide saturation of silicate melts at $1400 \mathrm{C}$ and 1 bar. J. Petrol. 43, 1049-1087.

Ohmoto, H., Kerrick, D.M., 1977. Devolatilisation equilibria in graphitic systems, Am. J. Sci., 277, 1013-1044.

Patten, C., Barnes, S.J., Mathez, E.A., Jenner, F.E., 2013. Partition coefficients of chalcophile elements between sulphide and silicate melts and the early crystallisation history of sulphide liquid: LA-ICP-MS analysis of MORB sulphide droplets. Chem. Geol. $358,170-188$.

Pinkerton, H., Stevenson R.J., 1992. Methods of determining the rheological properties of magma at sub-liquidus temperatures. J. Volcanol. Geotherm. Res. 53, 47-66.

Plescia, J.B., 1990. Recent flood lavas in the Elysium region of Mars. Icarus 88, 465-490.

Putirka, K.D., 2005. Mantle potential temperatures at Hawaii, Iceland, and the mid-ocean ridge system, as inferred from olivine phenocrysts: Evidence for thermally driven mantle plumes. Geochem. Geophys. Geosys. 6, Q05L08

Rice, J.W., Baker, V.R., 2015. New observations of martian outflow channel flood deposits. Lunar Planet. Sci. Conf. 46. CD-ROM (abs. \#2979).

Rice, A., Moore, J.M., 2001. Physical modelling of the formation of komatiite-hosted nickel deposits and review of the thermal erosion paradigm. Can. Mineral. 39, 491-503.

Righter, K., Chabot, N.L., 2011. Siderophile element constraints on the depth and extent of melting on early Mars. Meteorit. Planet. Sci. 46, 157-176.

Righter, K., Danielson, L.R., Pando, K.M., Williams, J., Humayun, M., Hervig, R.L., Sharp, T.G., 2015. Highly siderophile element (HSE) abundances in the mantle of Mars are due to core formation at high pressure and temperature. Meteorit. Planet. Sci. 50, 604-631. Righter, K., Pando, K., Danielson, L.R., 2009. Experimental evidence for sulfur-rich martian magmas: Implications for volcanism and surficial sulfur sources. Earth Planet. Sci. Lett. 288, 235-243.

Robertson, J., Ripley, E.M., Barnes, S.J., Li, C., 2015. Sulfur liberation from country rocks and incorporation in mafic magmas. Econ. Geol. 110, 1111-1123.

Robertson, J., Barnes, S.J., Le Vaillant, M., 2015. Dynamics of magmatic sulphide droplets during transport in silicate melts and implications for magmatic sulphide ore formation. $\mathrm{J}$. Petrol. 56, 2445-2472. 
Robie, R.A., Hemingway, B.S., Fisher, J.R., 1979. Thermodynamic properties of minerals and related substances at $298.15 \mathrm{~K}$ and 1 bar $\left(10^{5} \mathrm{~Pa}\right)$ pressure and at higher temperatures, US Geol. Surv. Bull. 1452.

Sautter, V., Fabre, C., Forni, O., et al., 2014. Igneous mineralogy at Bradbury Rise: the first ChemCam campaign at Gale crater. J. Geophys. Res. (Planets) 119, E1.

Sautter, V., Toplis, M.J., Wiens, R.C., et al., 2015. In situ evidence for continental crust on early Mars. Nat. Geosci. 8, 605-609.

Schmidt, M.E., Campbell, J.L., Gellert, R., 2014. Geochemical diversity in first rocks examined by the Curiosity Rover in Gale Crater: evidence for and significance of an alkali and volatile-rich igneous source. J. Geophys. Res. (Planets) 119, E1.

Schmidt, M.E., Schrader, C.M., McCoy, T.J., 2013. The primary $f \mathrm{O}_{2}$ of basalts examined by the Spirit rover in Gusev Crater, Mars: Evidence for multiple redox states in the martian interior. Earth Planet. Sci. Lett. 384, 198-208.

Schorghofer, N., 2010. Fast numerical method for growth and retreat of subsurface ice on Mars. Icarus 208, 598-607.

Shirai, N., Ebihara, M., 2004. Chemical characteristics of an olivine-phyric shergottite, Yamato-980459. Lunar Planet. Sci. Conf. 35. CD-ROM (abs. \#1511).

Siewert, J., Ferlito, C., 2008. Mechanical erosion by flowing lava. Contemp. Phys. 49, 4354.

Sklar, L., Dietrich, W.E., 1998. River longitudinal profiles and substrate incision models: Stream power and the influence of sediment supply. In: Tinkler, K.J., Wohl, E.E. (eds.), Rivers Over Rock. AGU, Washington, D.C., pp. 237-260.

Squyres, S.W., Arvidson, R.E., Bell, J.F., et al., 2012. Ancient Impact and Aqueous Processes at Endeavour Crater, Mars. Science 336, doi:10.1126/science.1220476.

Squyres, S.W., Knoll, A.H., 2005. Sedimentary rocks at Meridiani Planum: Origin, diagenesis, and implications for life on Mars. Earth Planet. Sci. Lett. 240, 1-10.

Stockstill-Cahill, K.R., Scott, A.F., Hamilton, V.E., 2008. A study of low-albedo deposits within Amazonis Planitia craters: evidence for locally derived ultramafic to mafic materials. J. Geophys. Res. 113, E07008.

Symonds, R.B., Reed, M.H., 1993. Calculation of multicomponent equilibria in gaseoussolid-liquid systems: Calculation methods, thermochemical data, and applications to studies of high-temperature volcanic gases with examples from Mount St. Helens. Am. J. Sci. 293, 758-864. 
Thompson, L.M., Schmidt, M.E., Spray, J.G., Berger, J.A., Fairen, A.G., Campbell, J.L., Perrett, G.M., Boyd, N., Gellert, R., Pradler, I., VanBommel, S.J., 2016 Potassium-rich sandstones within the Gale impact crater, Mars: The APXS perspective, J. Geophys. Res. (Planets) 121, doi:10.1002/2016JE005055.

Toplis, M.J., 2005. The thermodynamics of iron and magnesian partitioning between olivine and liquid: criteria for assessing and predicting equilibrium in natural and experimental systems. Contrib. Mineral. Petrol. 149, 22-39.

Toulmin, P., Barton, P.B., 1964. A thermodynamic study of pyrite and pyrrhotite: Geochim. Cosmochim. Acta 28, 641-671.

Vaniman, D.T., Bish, D.L., Ming, D.W., et al., 2014. Mineralogy of a Mudstone at Yellowknife Bay, Gale Crater, Mars. Science 343, doi:10.1126/science.1243480

Vaucher, J., Baratoux, D., Toplis, M.J., Pinet, P., Mangold, N., Kurita, K., 2009. The morphologies of volcanic landforms at Central Elysium Planitia: Evidence for recent and fluid lavas on Mars. Icarus 200, 39-51.

Wang, Z., Becker, H., 2017. Chalcophile elements in Martian meteorites indicate low sulfur content in the martian interior and a volatile element-depleted late veneer. Earth Planet. Sci. Lett. 463, 56-68.

Warner, N., Gupta, S., Muller, J.P., Kim, J.R., Lin, S.Y., 2009. A refined chronology of catastrophic outflow events in Ares Vallis, Mars. Earth Planet. Sci. Lett. 288, 58-69.

Williams, D.A., Fagents, S.A., Greeley, R., 2000. A re-evaluation of the emplacement and erosional potential of turbulent, low-viscosity lavas on the Moon. J. Geophys. Res. 105, E8.

Williams, D.A., Greeley, R., Fergason, R.L., Neukum, G., 2009. The Circum-Hellas Volcanic Province, Mars: Overview. Planet. Space Sci., 57, 895-916.

Williams, D.A., Greeley, R., Hauber, E., Gwinner, K., Neukum, G., 2005. Erosion by flowing martian lava: New insights for Hecates Tholus from Mars Express and MER data. J. Geophys. Res. 110, E5.

Williams, D.A., Kerr, R.C., Lesher, C.M., Barnes, S.J., 2001. Analytical/numerical modelling of komatiite lava emplacement and thermal erosion at Perseverance, Western Australia. J. Volcanol. Geotherm. Res. 110, 27-55.

Williams, D.A., Ross, C.K., Lesher, C.M., 1998. Emplacement and erosion by Archean komatiite lava flows at Kambalda: revisited. J. Geophys. Res. 103, B11.

Williams, R.M.E., Grotzinger, J.P., Dietrich, W.E., et al., 2013. Martian Fluvial Conglomerates at Gale Crater. Science 340, 1068-1092. 
Wilson, L., Mouginis-Mark, P.J., 2003. Phreatomagmatic explosive origin of Hrad Vallis, Mars. J. Geophys. Res. 108, E8.

Yang, S., Humayun, M., Righter, K., Jefferson, G., Fields, D., Irving, A.J., 2015. Siderophile and chalcophile element abundances in shergottites: Implications for martian core formation. Meteorit. Planet. Sci. 50, 691-714.

Figures
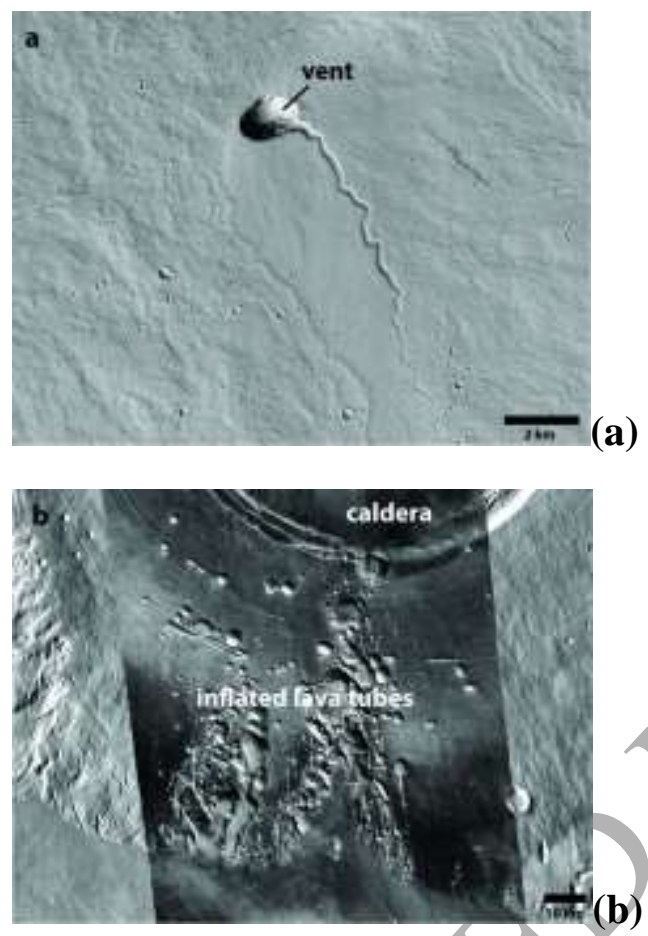

(a)
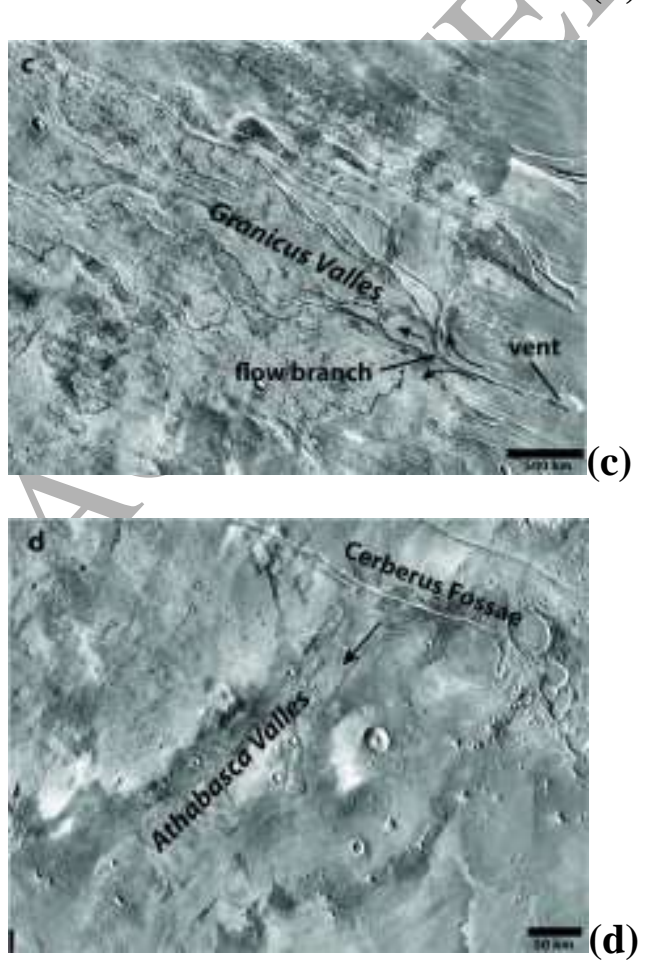
Figure 1. a) Volcanic vent and associated lava channel NE of Ascraeus Mons (High Resolution Imaging Science Experiment, HiRISE, image ESP-030348-1925 superimposed on High Resolution Stereo Colour Imager, HRSC, image H-2021-0001-ND3); b) Partially collapsed lava tubes at the southern flank of the Arsia Mons shield volcano (HRSC image H-0263-0000-ND4 superimposed on Thermal Emission Imaging System, THEMIS, Day IR global mosaic); c) Granicus Valles, and its surroundings. The channel system emanates west of Elysium Mons and propagates into the Utopia Planitia lowland (THEMIS, Day IR global mosaic); d) Channelled lava flows at Athabasca Valles (Elysium region) that emanate at Cerberus Fossae (THEMIS, Day IR global mosaic).

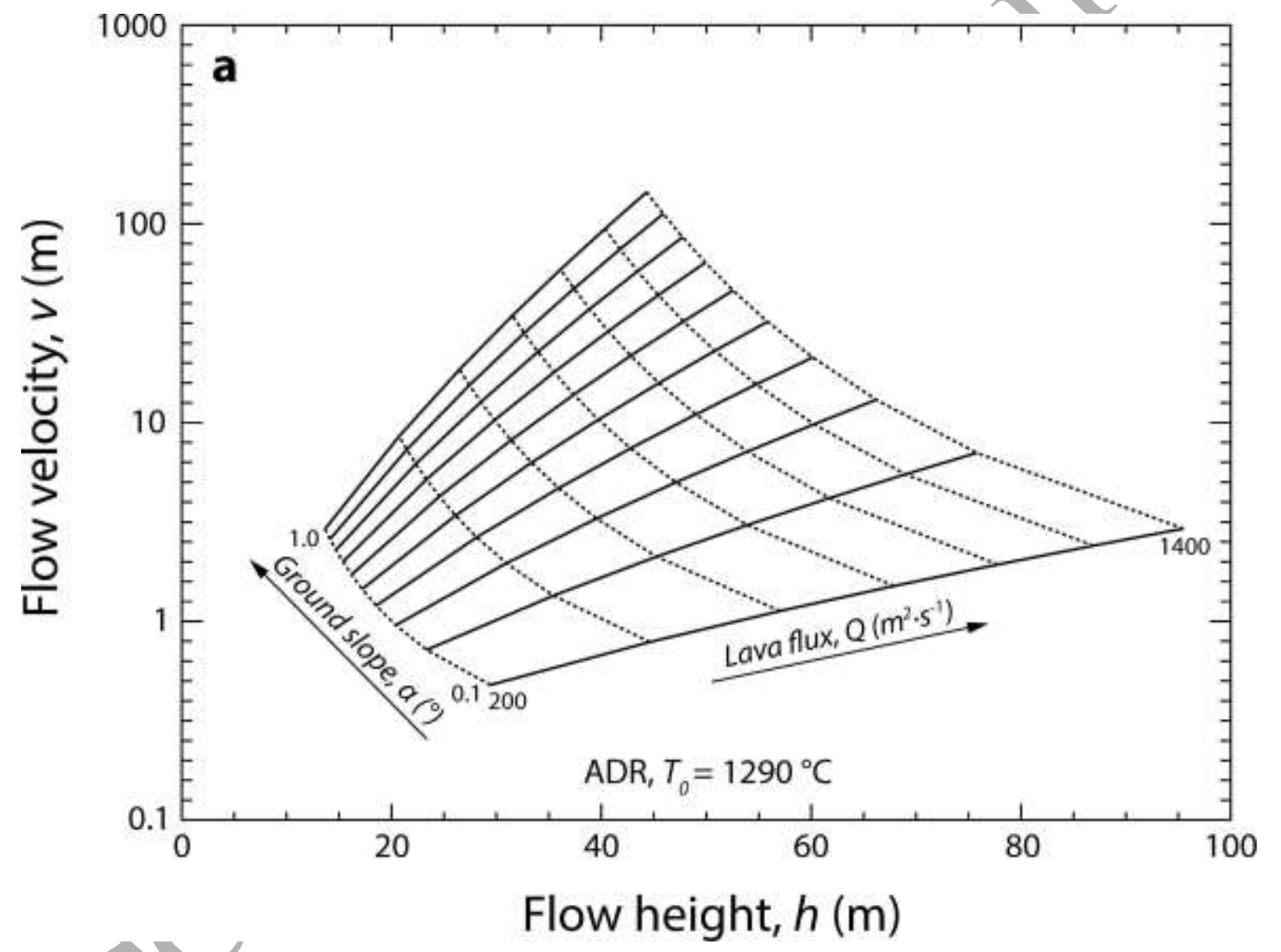




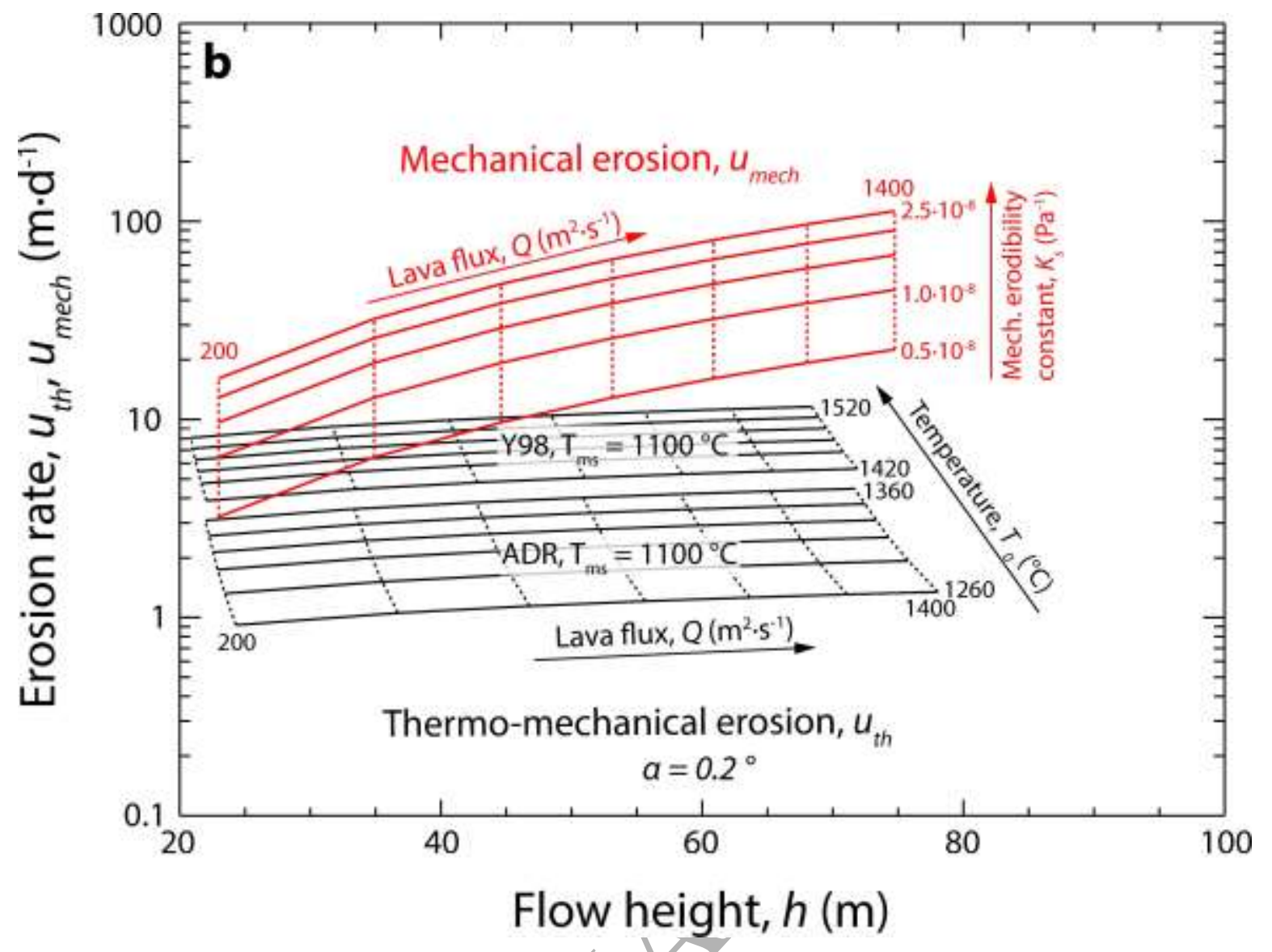

Figure 2. a) Dependency of flow height (h) and flow velocity (v) on lava flow rate per unit width $(\mathrm{Q})$ and ground slope $(\alpha)$ for Hesperian Adirondack-class (ADR) lava (with $\mathrm{T}=\mathrm{T}_{\text {liq, }}$ Table 2, and the corresponding viscosity calculated with the equations in Giordano et al., 2008). Flow height increases with flow rate, but decreases with ground slope. Flow velocity is inversely proportional to flow height b) Dependency of mechanical erosion $\left(\mathrm{u}_{\text {mech }}\right)$ on flow rate per unit width, $\left(\mathrm{Q}=200\right.$ to $\left.1400 \mathrm{~m}^{2} \cdot \mathrm{s}^{-1}\right)$ and the erodibility constants for variably consolidated substrates $\left(\mathrm{K}_{\mathrm{s}}=0.5 \cdot 10^{-8}\right.$ to $\left.2.5 \cdot 10^{-8} \mathrm{~Pa}^{-1}\right)$. Thermo-mechanical erosion ( $\mathrm{u}_{\text {therm }}$ by Adirondack-class (ADR) and Y-980459 (Y98) lava is explored for variable flow rates and eruption temperatures (Table 2). The ground slope $(\alpha)$ is $0.1^{\circ}$, and the substrate melting temperature $\left(\mathrm{T}_{\mathrm{ms}}\right)$ is $1100{ }^{\circ} \mathrm{C}$. See text, Table 2, and Table 3, for discussion of the physical-chemical model input parameters, and Table 1 for abbreviations and entities. 


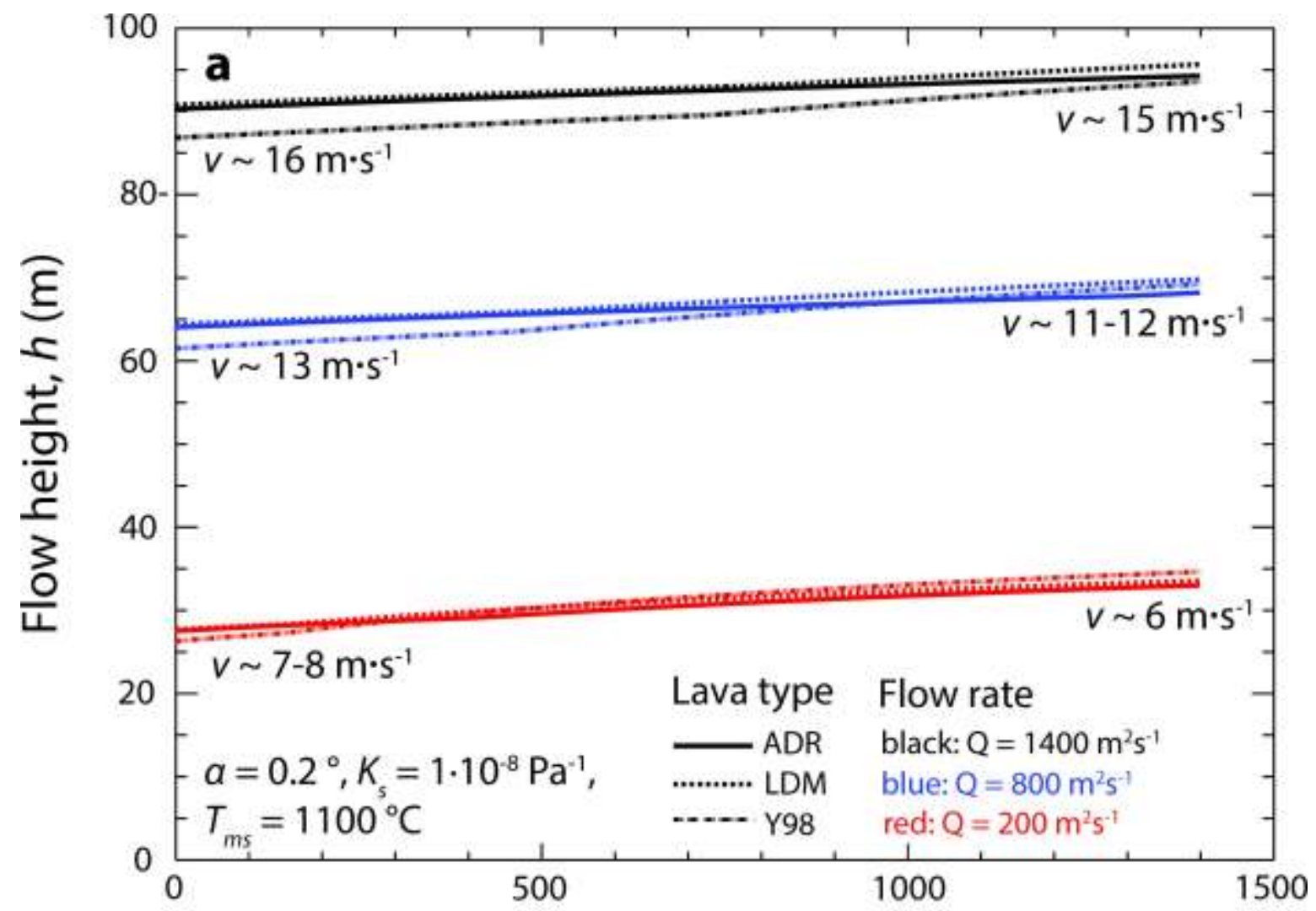

Flow distance $(\mathrm{km})$

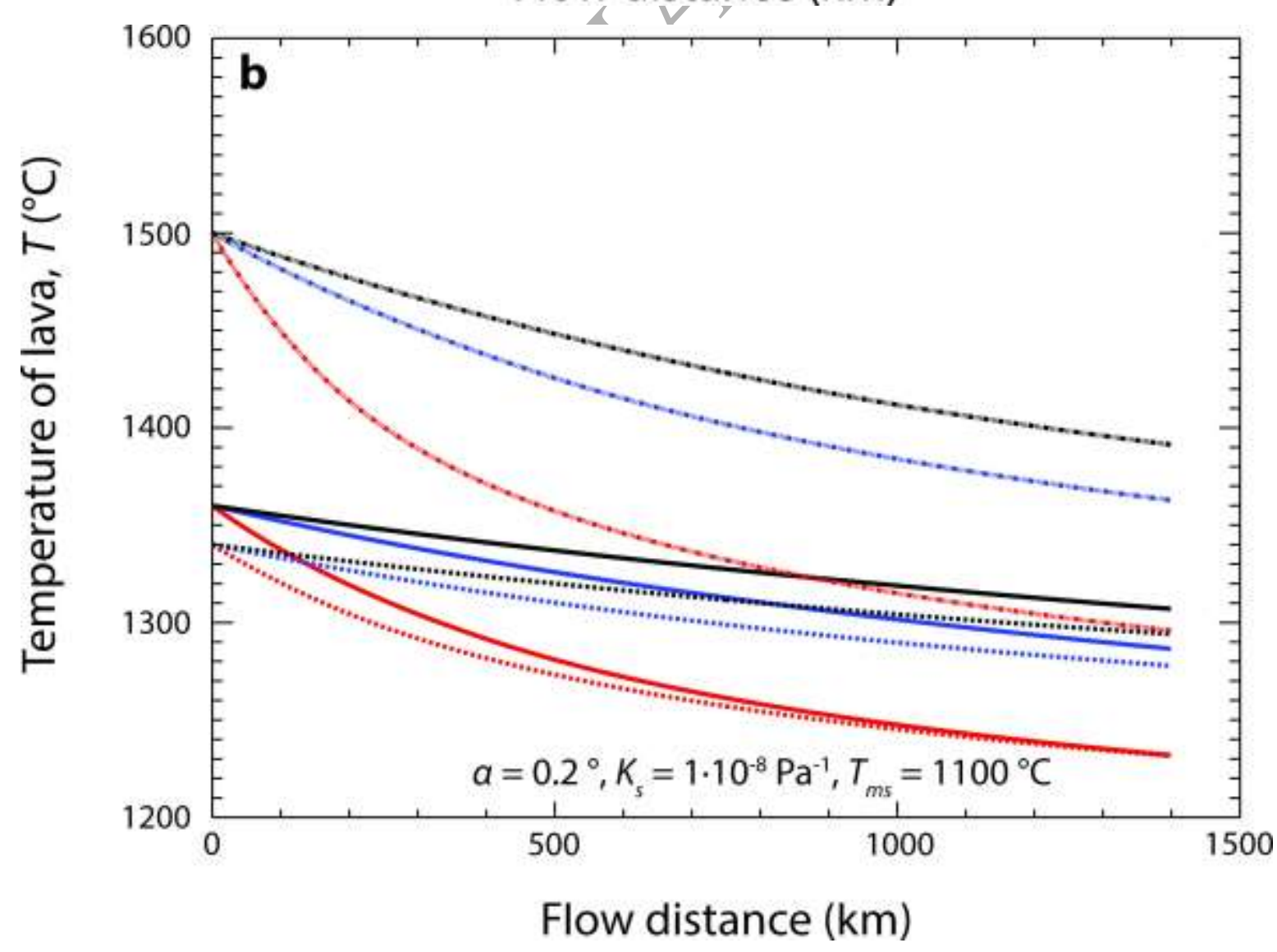




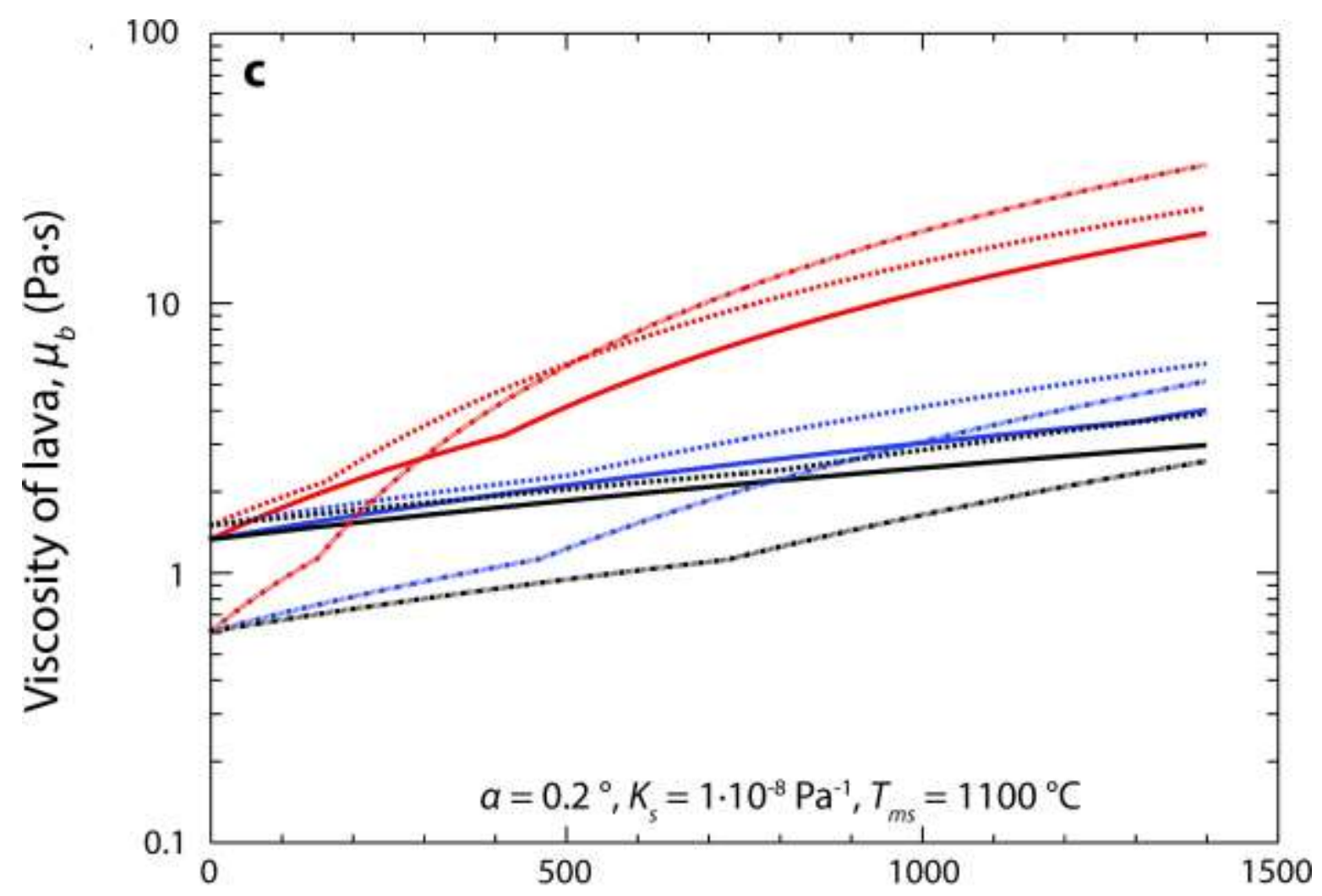

Flow distance $(\mathrm{km})$

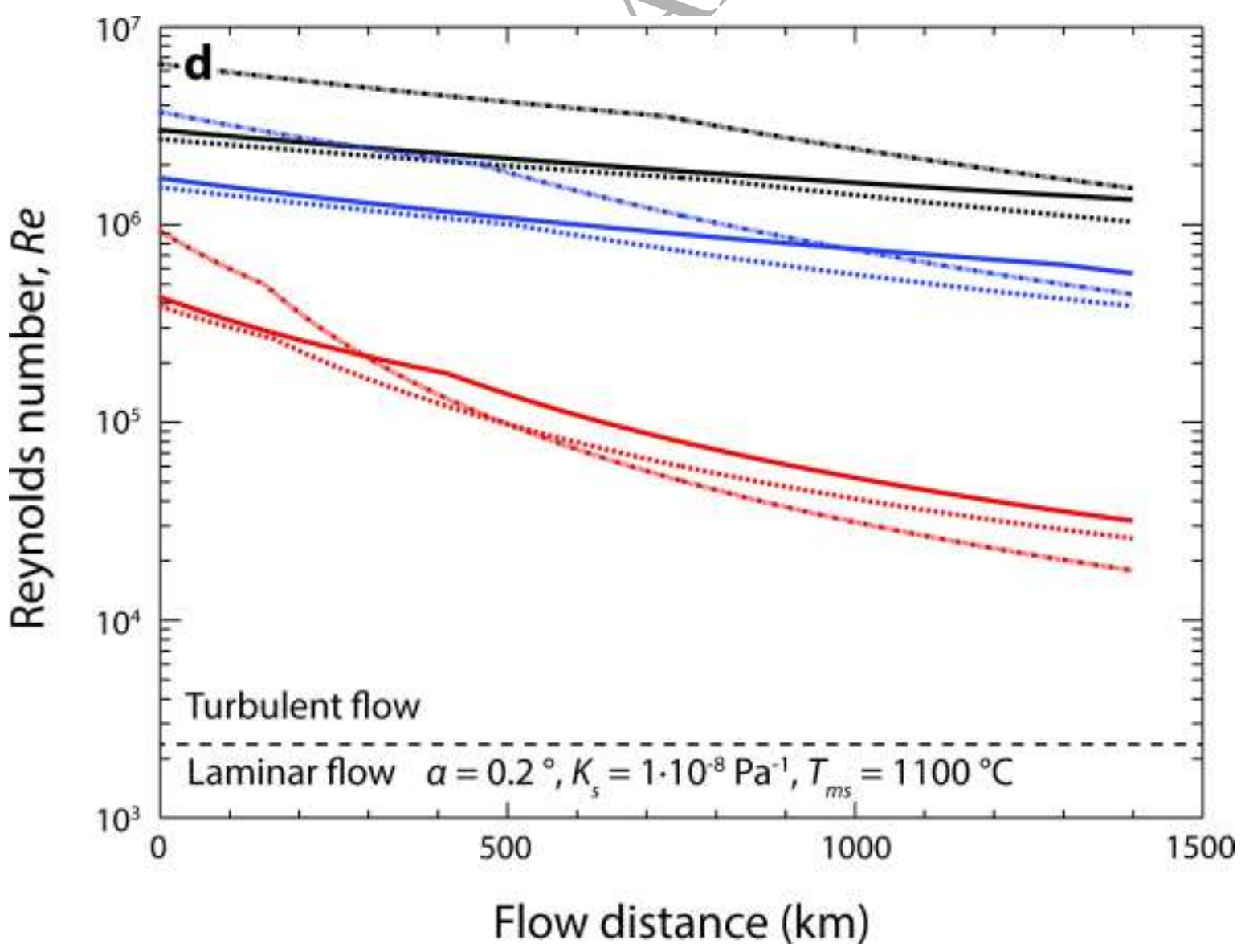



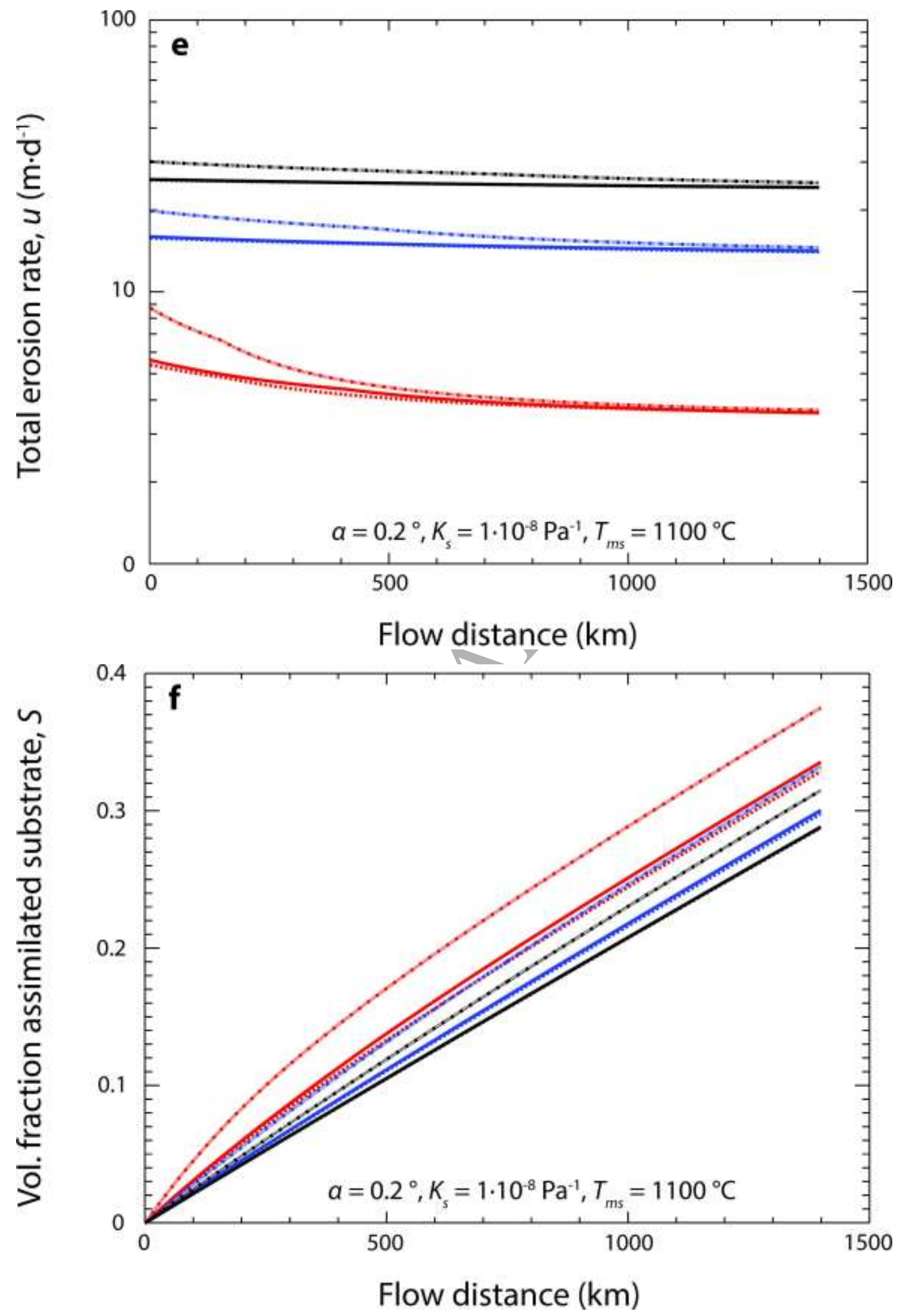

Figure 3. Flow of Hesperian Adirondack-class lava (ADR), Amazonian low-degree mantle melt (LDM) and Y-980459 lava (Y98) as function of flow distance over moderately 
consolidated $\left(\mathrm{K}_{\mathrm{s}}=1 \cdot 10^{-8} \mathrm{~Pa}^{-1}\right)$ sulfide-rich model substrate (Table 3). Model ground slope $(\alpha)$ is $0.2^{\circ}$, substrate melting temperature $\left(\mathrm{T}_{\mathrm{ms}}\right)$ is $1100{ }^{\circ} \mathrm{C}$, and flow rates per unit width (Q) of 200, 800 and $1400 \mathrm{~m}^{2} \cdot \mathrm{s}^{-1}$. a) flow height; b) lava temperature; c) lava viscosity; d) Reynolds number; e) total erosion rate; f) fraction of assimilated substrate. The abrupt changes in the lava viscosity and Reynolds number trajectories in (c) and (d) are due to the onset of olivine fractionation $\left(\mathrm{T}<\mathrm{T}_{\text {liq }}\right.$ ). See text, Table 2, and Table 3, for discussion of the physical-chemical model input parameters, and Table 1 for abbreviations and entities.

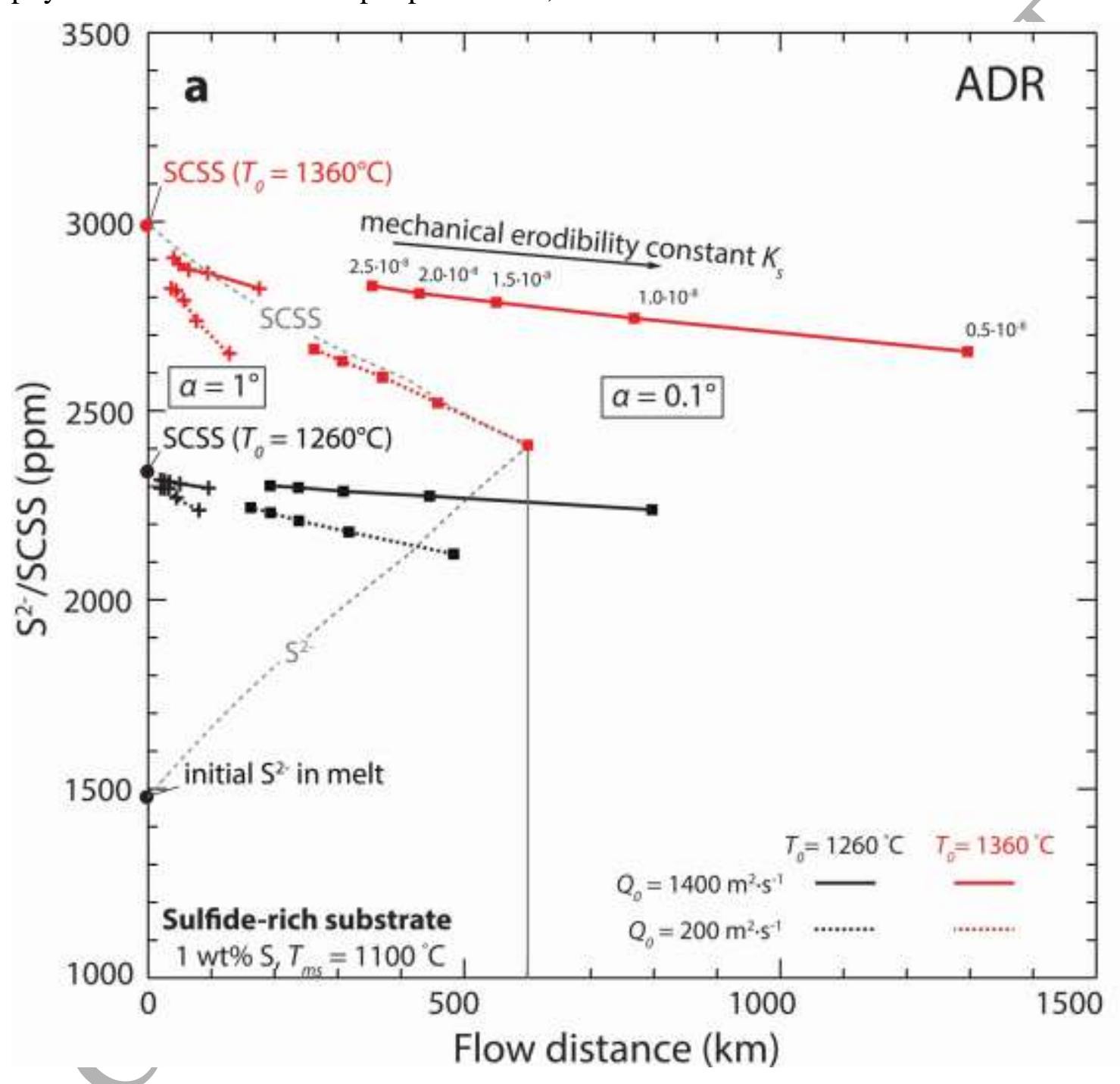




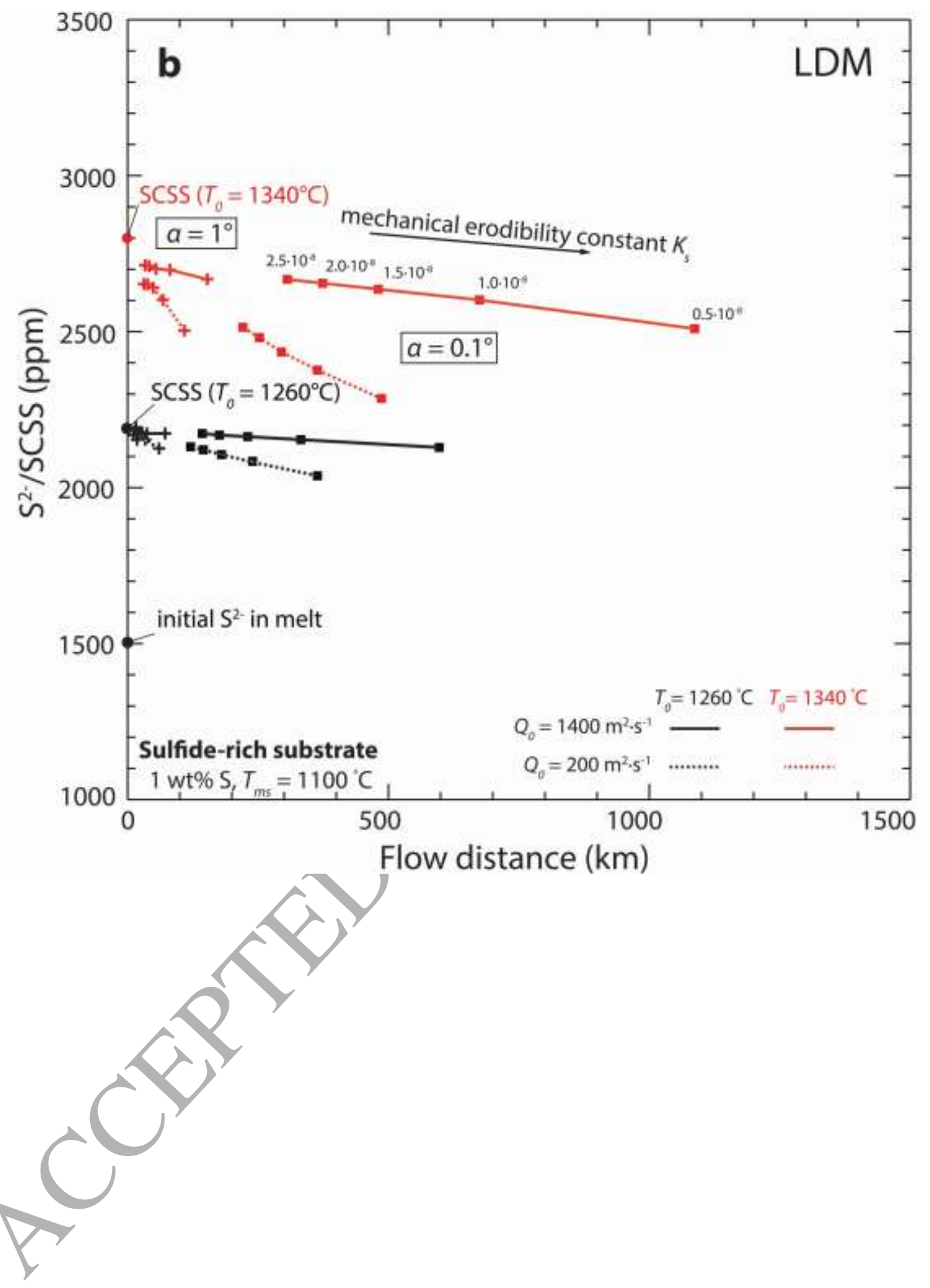




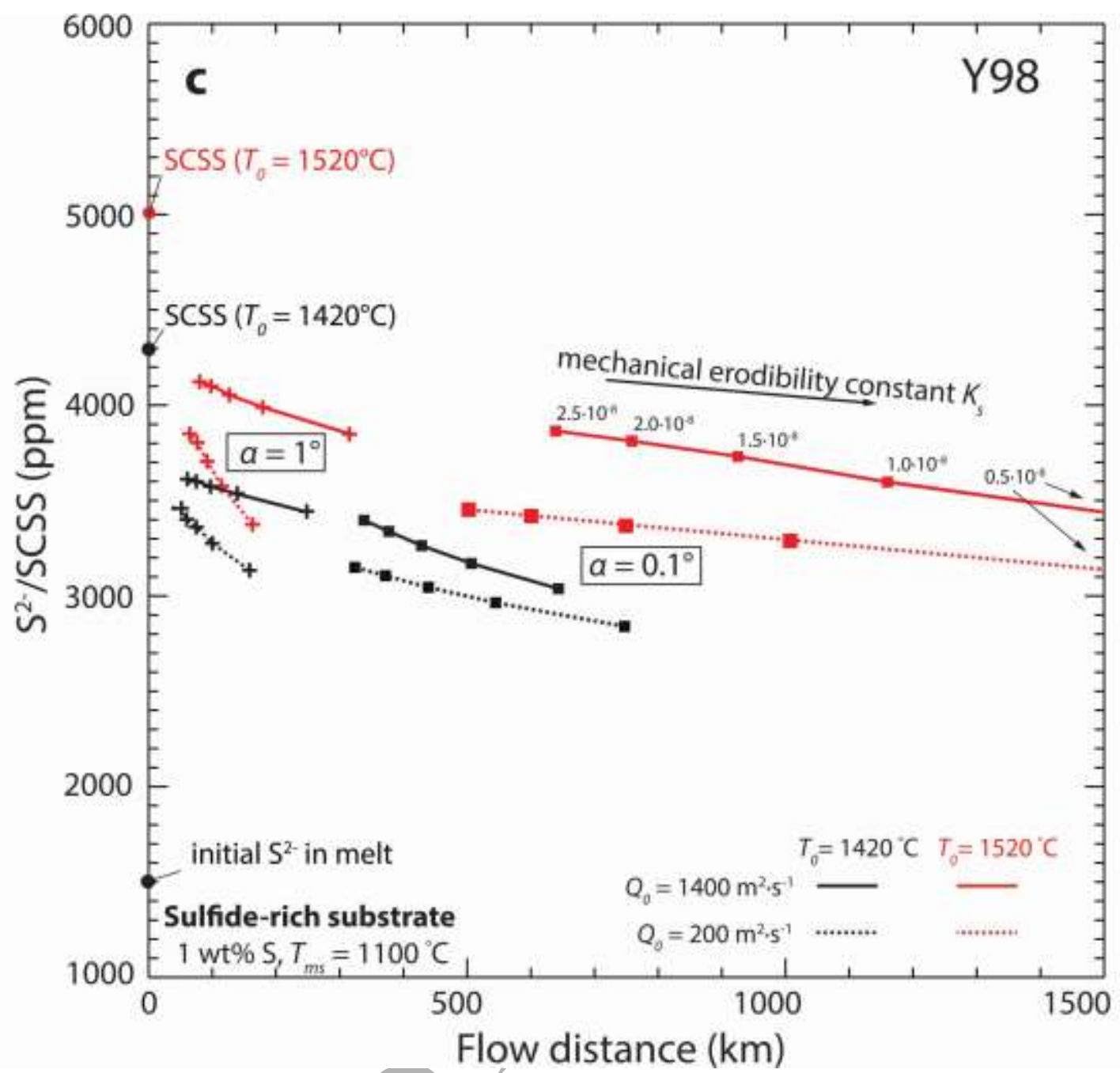

Figure 4. Simulations of sulfide saturation in Noachian-Hesperian Adirondack-class (ADR), Amazonian low-degree mantle melt (LDM) and Amazonian Y-980459 (Y98) lava flows as function of flow distance $(1400 \mathrm{~km})$ over sulfide-rich model substrate. Sulfide saturation is explored for different ground slopes $\left(\alpha=0.1\right.$ and $\left.1.0^{\circ}\right)$, flow rates per unit width $\left(\mathrm{Q}=200\right.$ and $\left.1400 \mathrm{~m}^{2} \cdot \mathrm{s}^{-1}\right)$, eruption temperatures (Table 2), and mechanical erodibility constants that are appropriate for strongly consolidated to unconsolidated sedimentary substrates $\left(\mathrm{K}_{\mathrm{s}}=0.5 \cdot 10^{-8}\right.$ to $\left.2.5 \cdot 10^{-8} \mathrm{~Pa}^{-1}\right)$. Each data point represents sulfide supersaturation in a respective modeling scenario, which is achieved at the intersection of $\mathrm{S}^{2-}$ and SCSS during flow, erosion and assimilation. The trajectories of $\mathrm{S}^{2-}$ and SCSS are exemplary shown by dashed grey lines in (a) for a selected ADR lava emplacement scenario, in which $\alpha=0.1^{\circ}, \mathrm{Q}=200 \mathrm{~m}^{2} \cdot \mathrm{s}^{-1}, \mathrm{~T}_{0}=1360{ }^{\circ} \mathrm{C}$, and strongly consolidated substrate accounts for sulfide batch segregation at $\sim 600 \mathrm{~km}$ flow distance. The black and red lines connect simulations in which all model input parameters other than the mechanical erodibility constants are held equal. Substrate melting is assumed to be initiated with plagioclase/clay melting at $1100{ }^{\circ} \mathrm{C}$. Initial sulfur in the melt and in the 
substrate is $1500 \mathrm{ppm} \mathrm{S}$ and $1 \mathrm{wt} \% \mathrm{~S}$, respectively. See text, Table 2, and Table 3, for discussion of the physical-chemical model input parameters, and Table 1 for abbreviations and entities.

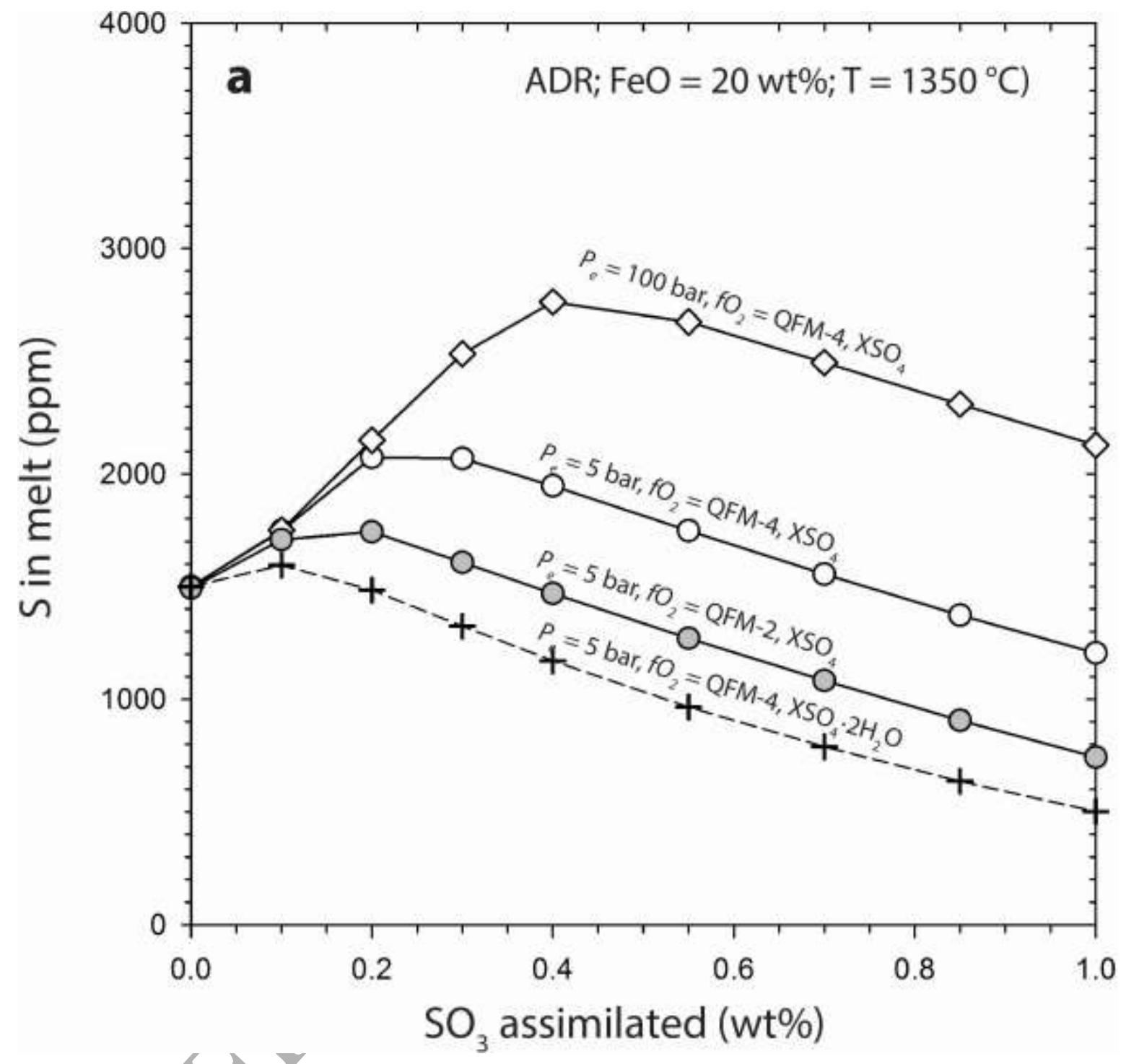




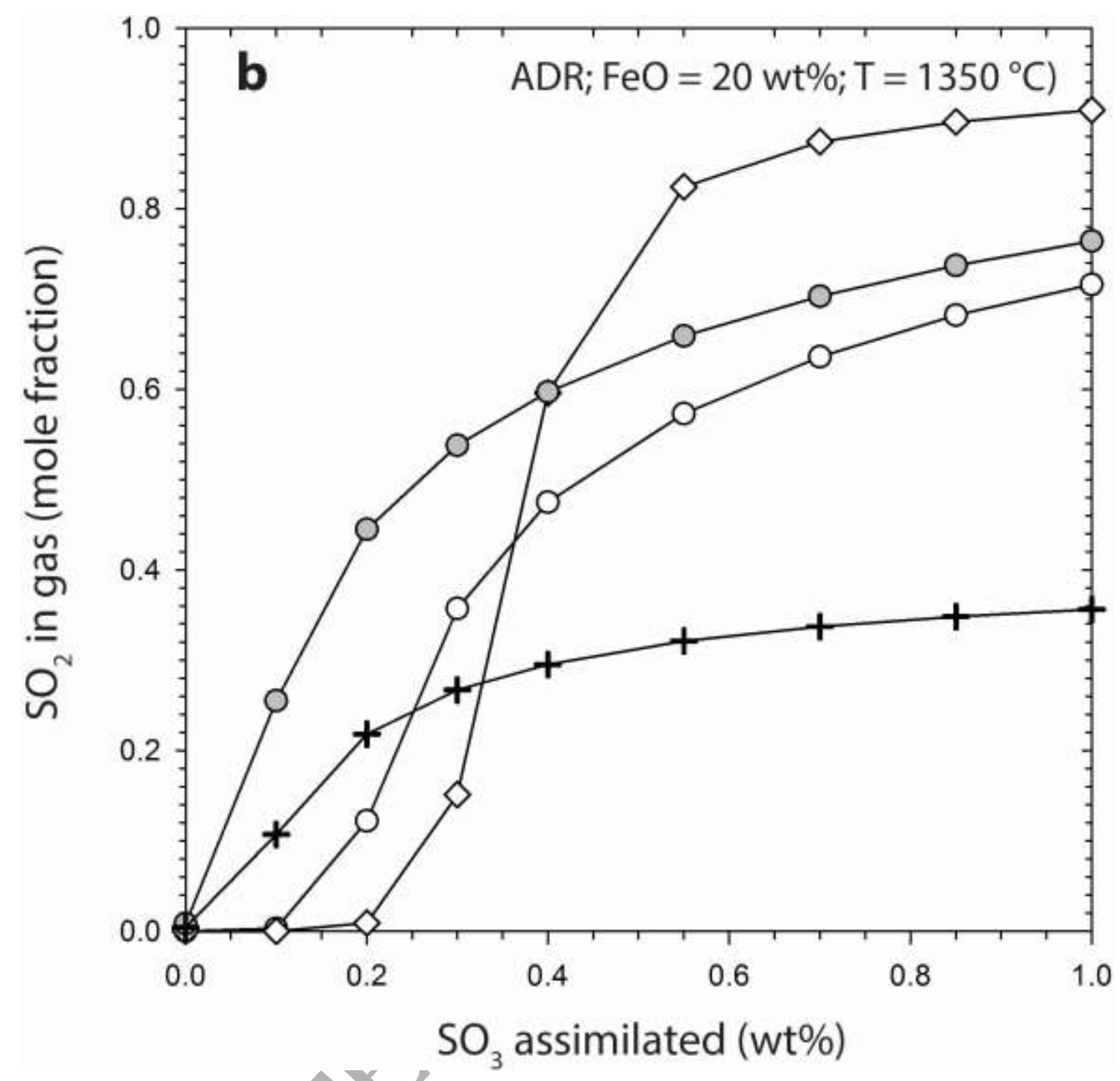




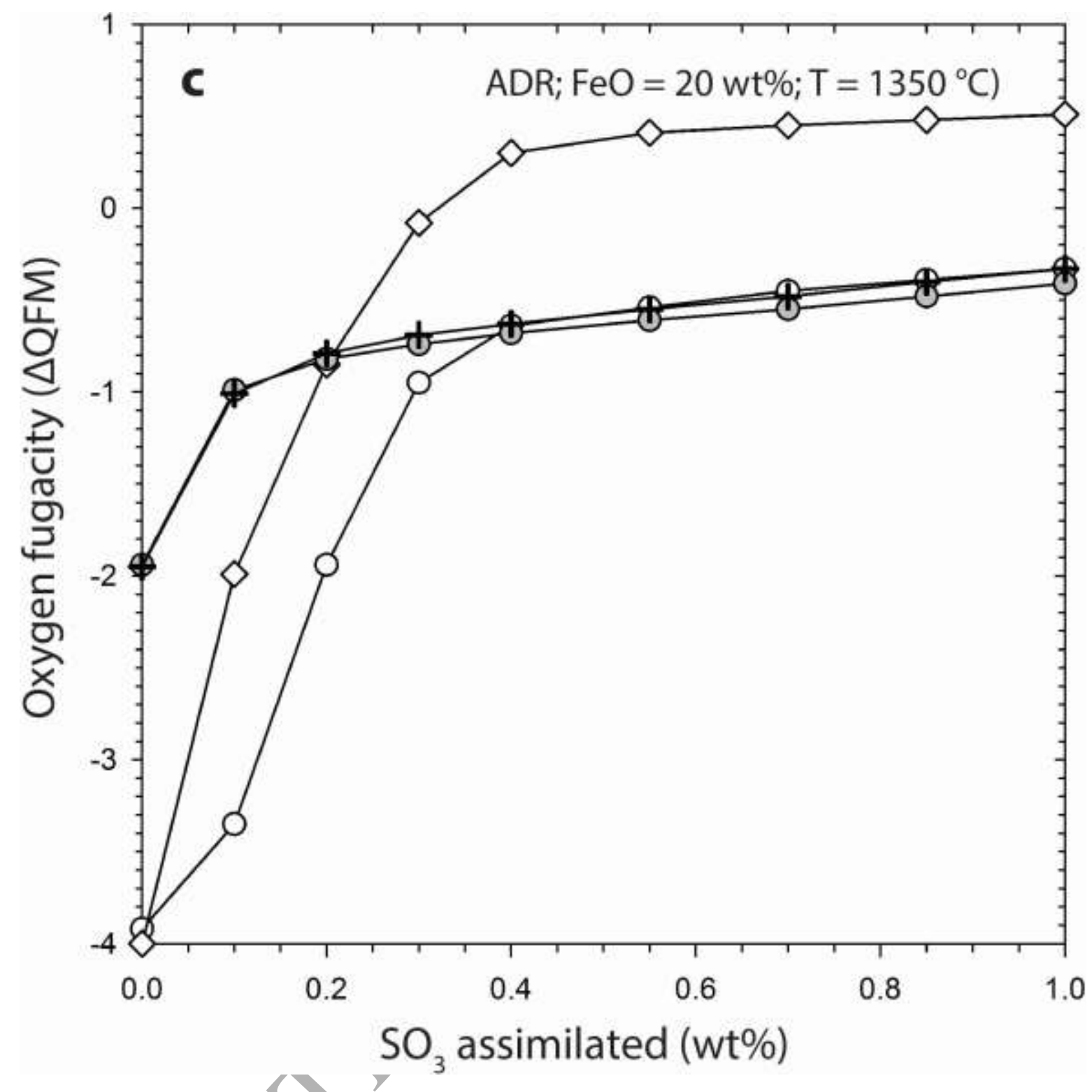




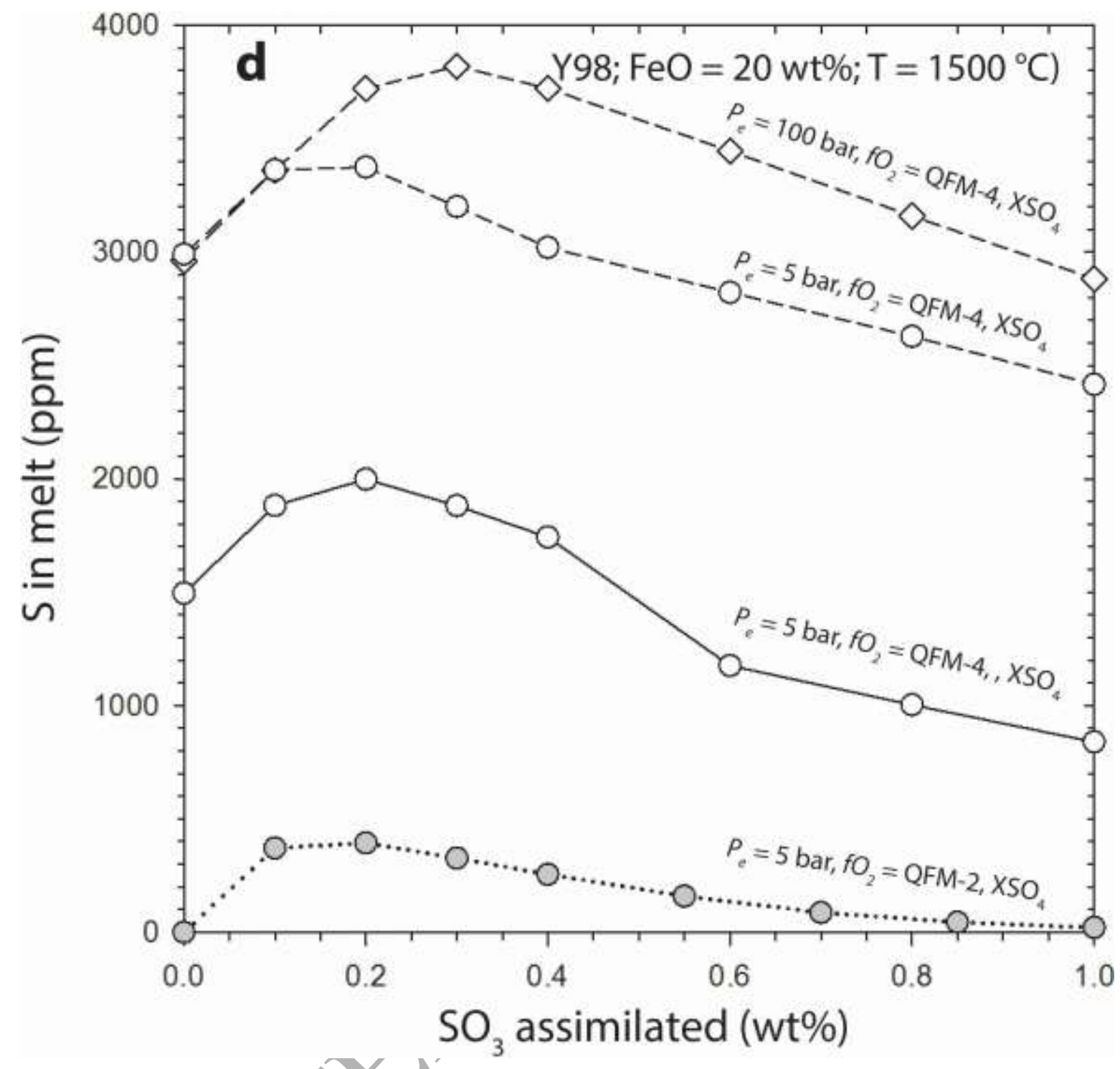




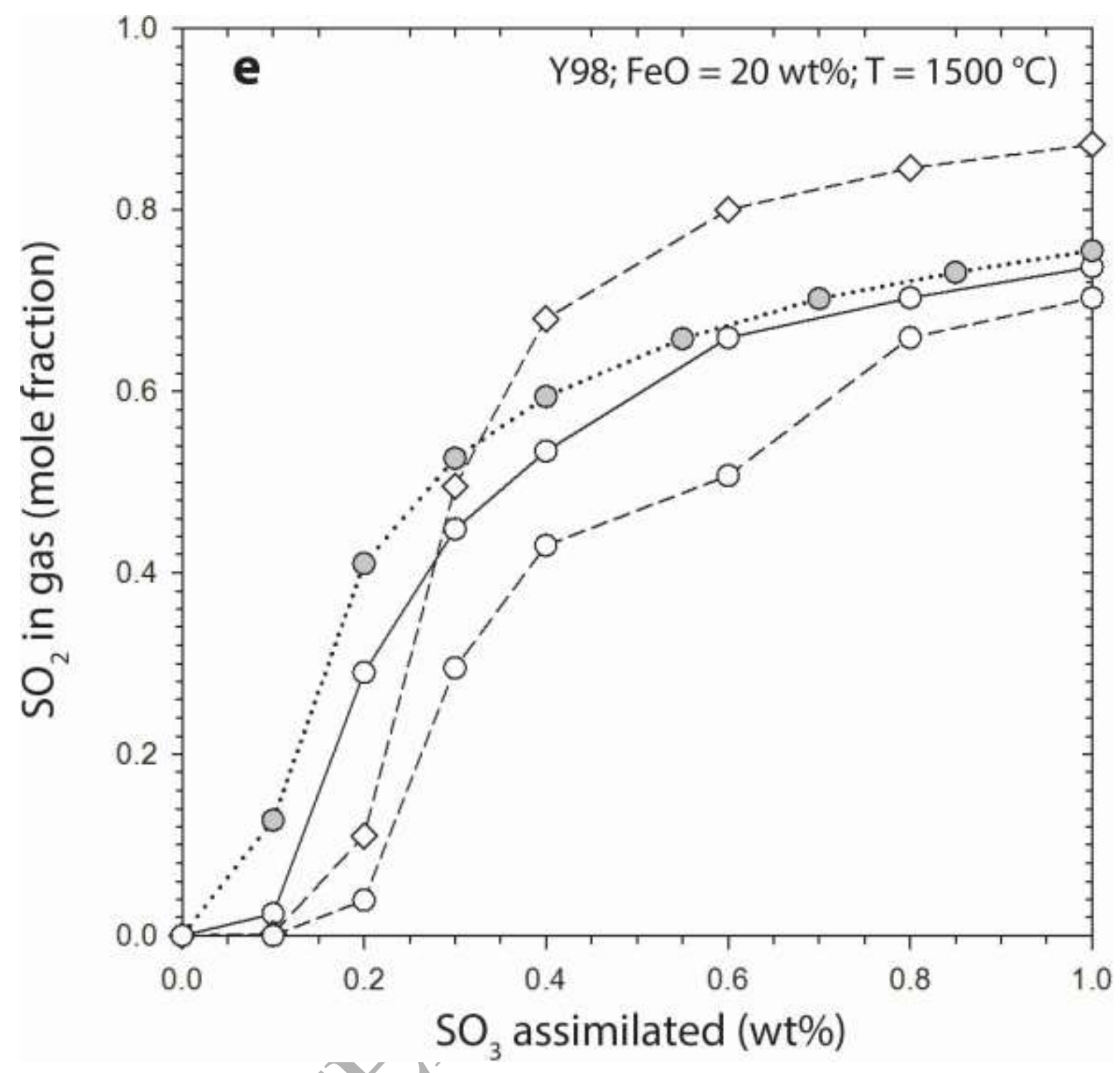




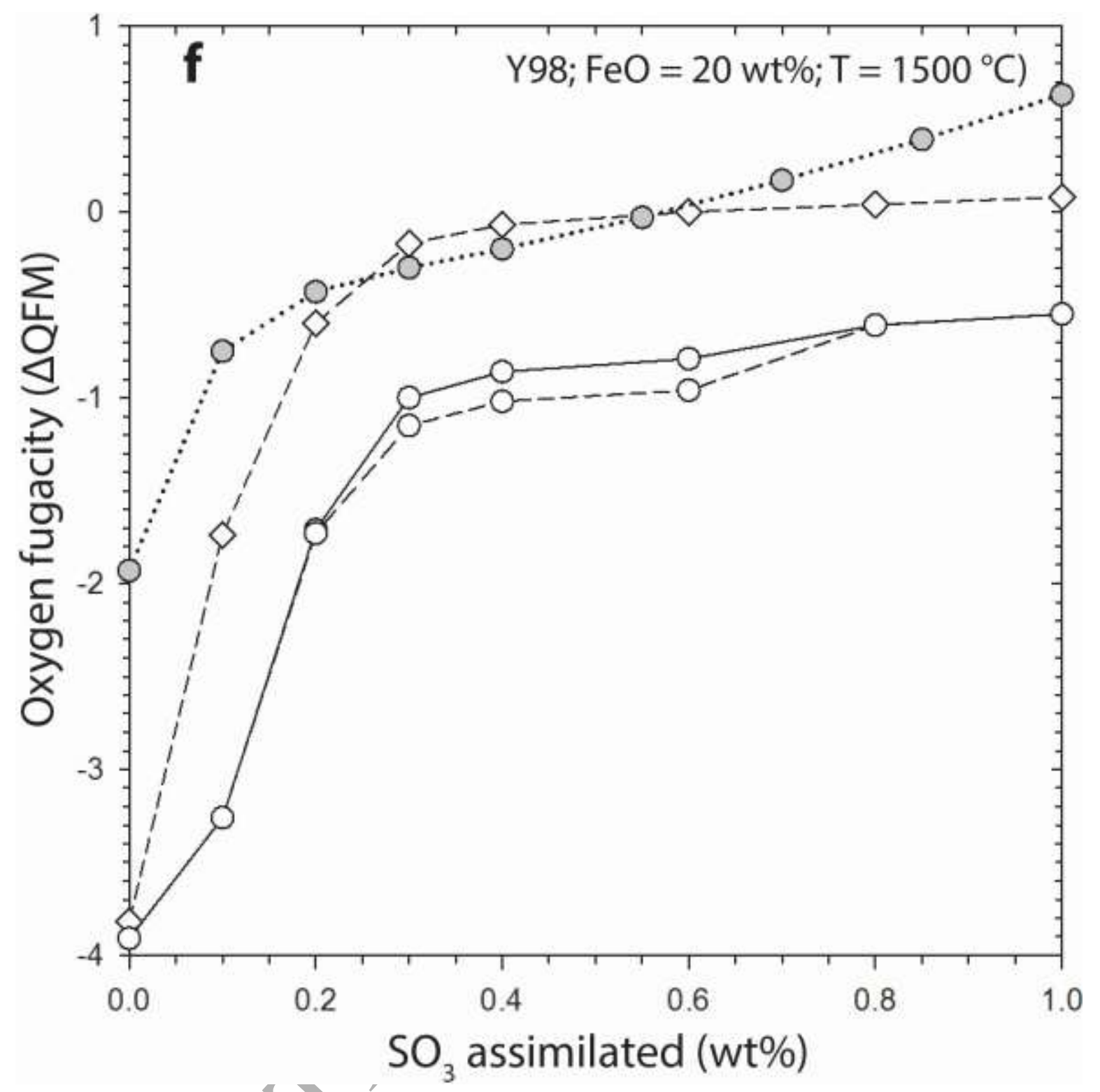

Figure 5. Results of isobaric and isothermal closed-system melt-gas equilibrium calculations in the C-H-O-S fluid system for the stepwise assimilation of anhydrous $\left(\mathrm{XSO}_{4}\right)$ and hydrous $\left(\mathrm{XSO}_{4} \cdot 2 \mathrm{H}_{2} \mathrm{O}\right)$ sulfate: i) Hesperian Adirondack-class (ADR) lava and Amazonian low-degree mantle melt (LDM) with $1350{ }^{\circ} \mathrm{C}$ and $20 \mathrm{wt} \% \mathrm{FeO}$, ii) Amazonian Y-980459 (Y98) melt with $1500{ }^{\circ} \mathrm{C}$ and $16 \mathrm{wt} \% \mathrm{FeO}$. Sulfur in melt (a and d), oxygen fugacity ( $b$ and e), and $\mathrm{SO}_{2}$ in the gas (c and $\mathrm{f}$ ), are plotted versus $\mathrm{SO}_{3}$ assimilated. The detailed calculation results are listed in Table 4. 


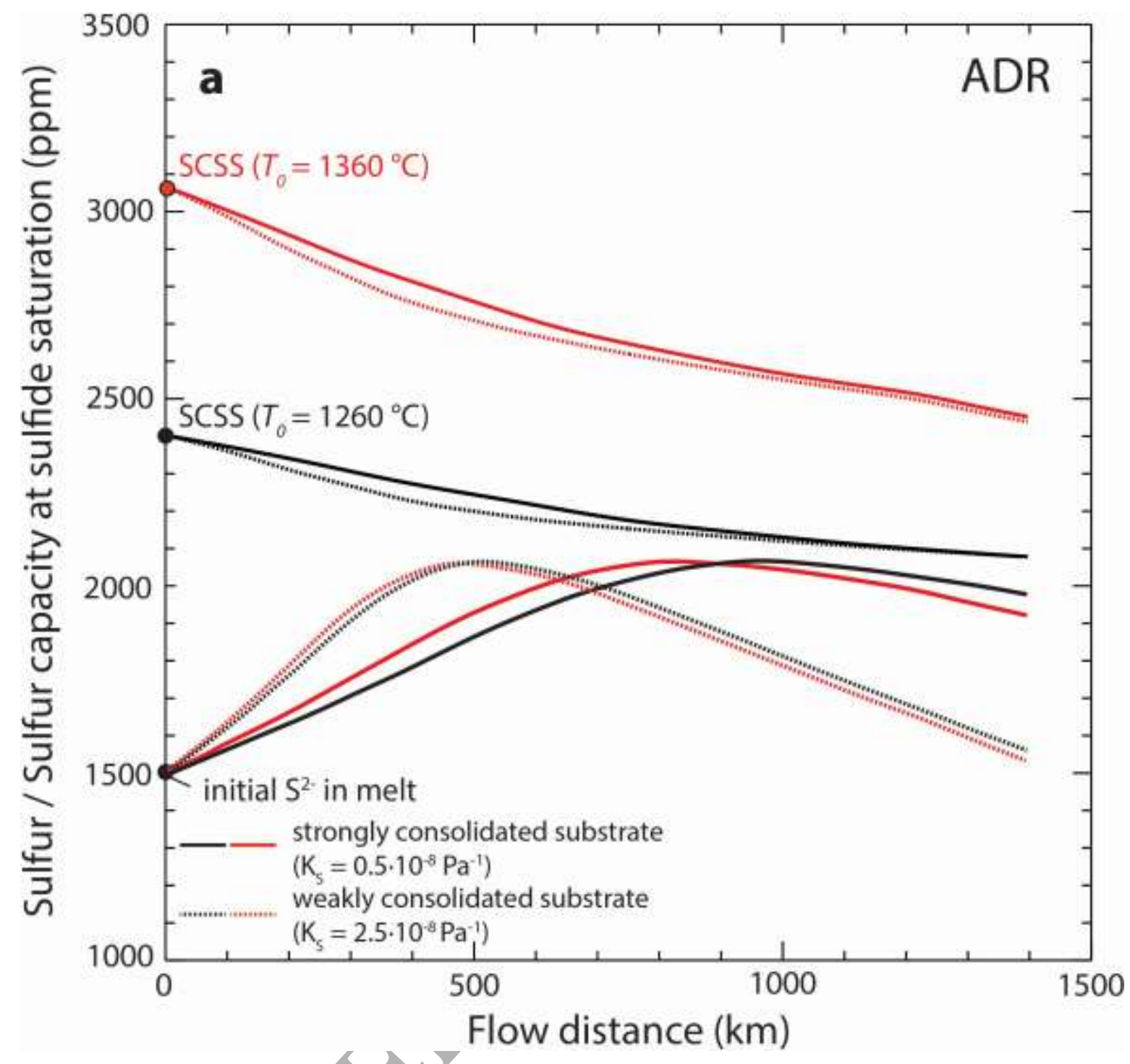




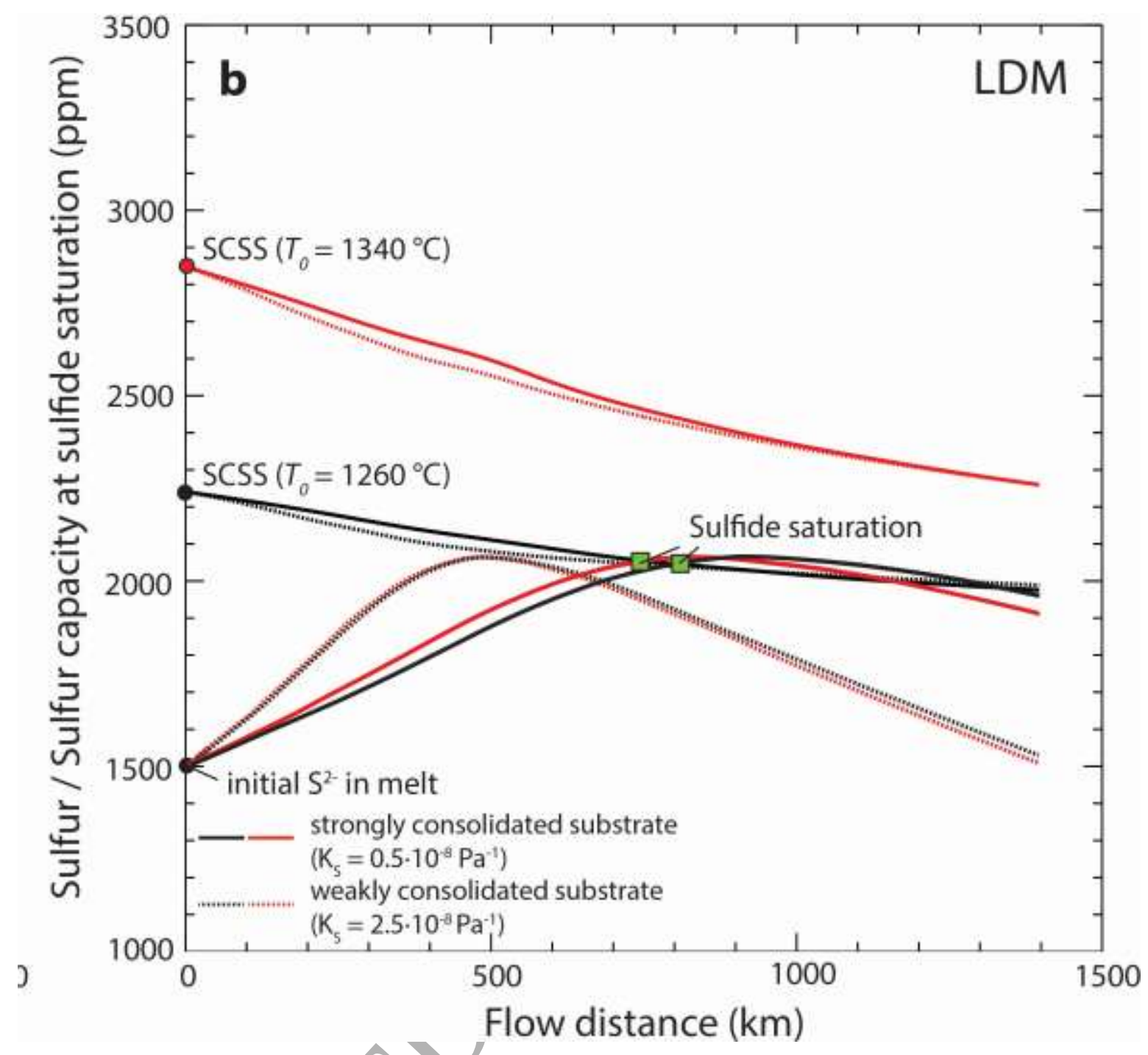




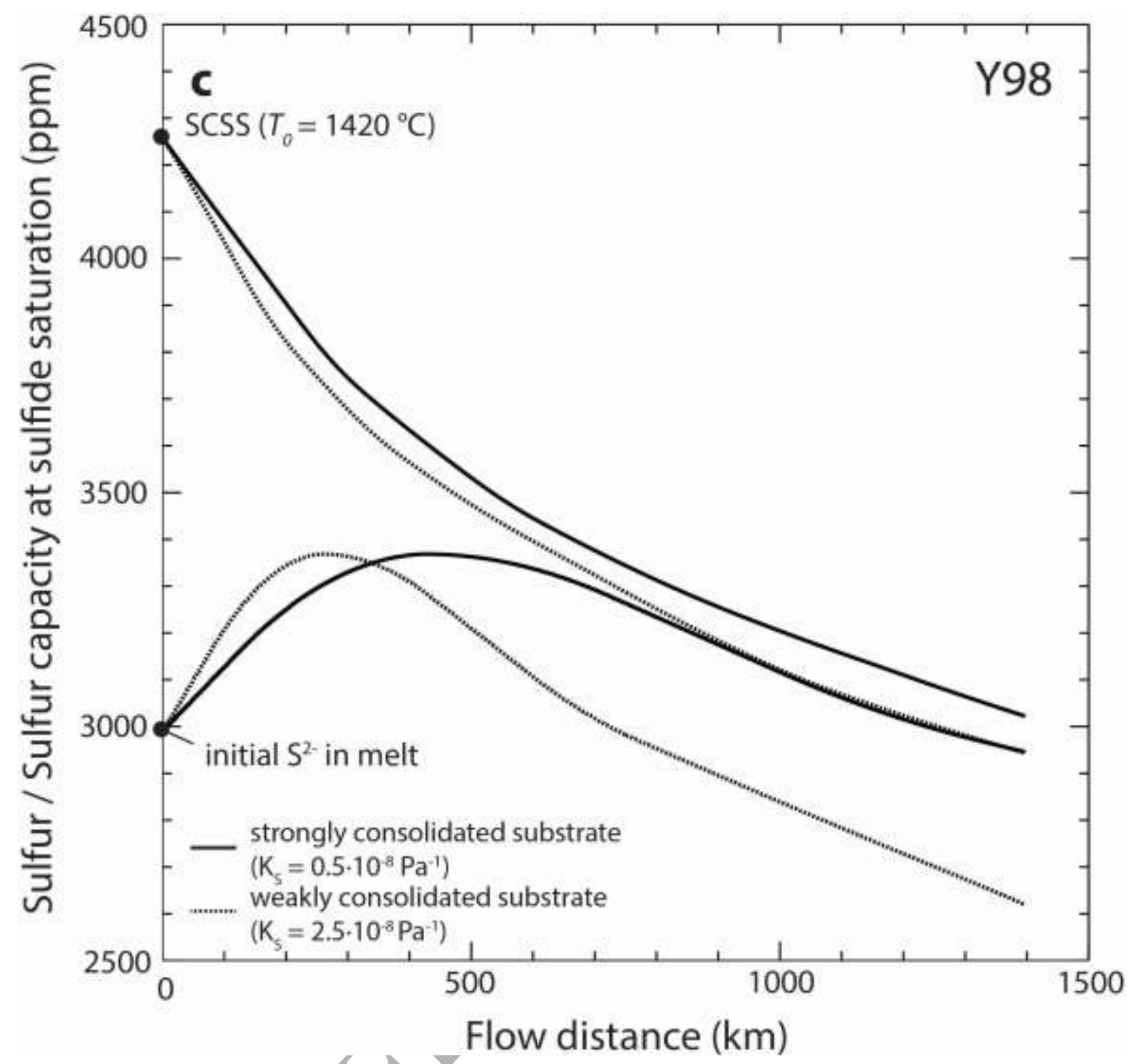

Figure 6. Modeling of sulfide saturation in Hesperian Adirondack-class (ADR), Amazonian low-degree mantle melt (LDM) and Y-980459 (Y98) lava flows at variable eruption temperatures as function of flow distance over unconsolidated $\left(\mathrm{K}_{\mathrm{s}}=2.5 \cdot 10^{-8} \mathrm{~Pa}^{-1}\right)$ to strongly consolidated $\left(\mathrm{K}_{\mathrm{s}}=0.5 \cdot 10^{-8} \mathrm{~Pa}^{-1}\right)$ sulfate-rich model substrate that contains 5 $\mathrm{wt} \% \mathrm{SO}_{3}$ as anhydrous sulfate $\left(\mathrm{XSO}_{4}\right)$. Lava erosion simulations are done for shallow ground slope $\left(\alpha=0.1-^{\circ}\right)$ and intermediate flow rate per unit width $\left(\mathrm{Q}=800 \mathrm{~m}^{2} \cdot \mathrm{s}^{-1}\right)$. Substrate melting is initiated at $1100{ }^{\circ} \mathrm{C}$. The $\mathrm{S}^{2-}$ in melt trajectories are derived from the volatile degassing calculations at 5 bar, low oxygen fugacity $\left(f \mathrm{O}_{2}=\mathrm{QFM}-4\right), 1500 \mathrm{ppm} \mathrm{S}$ for ADR and LDM, and 3000 ppm S for Y98 (Table 4). Sulfide saturation in (b) is attained at the intersection of the $\mathrm{S}^{2-}$ and the SCSS trajectories. See text, Table 2, Table 3, and Table 4, for discussion of the physical-chemical model input parameters, and Table 1 for abbreviations and entities. 
Tables

Table 1. Notations and parameter entities.

\begin{tabular}{|c|c|}
\hline$\alpha$ & Ground slope $\left(^{\circ}\right)$ \\
\hline$\Delta \mathrm{S}$ & Incremental substrate assimilation rate \\
\hline$\Delta \mathrm{T}$ & Incremental temperature decrease of lava $\left({ }^{\circ} \mathrm{C}\right)$ \\
\hline$\Delta \mathrm{T}$ & Incremental flow time (s) \\
\hline$\Delta \mathrm{x}$ & Incremental flow distance $(\mathrm{m})$ \\
\hline$\Delta \mathrm{X}$ & Incremental mass fraction of olivine crystallization $\left({ }^{\circ} \mathrm{C}^{-1}\right)$ \\
\hline$\Delta \mathrm{X} / \Delta \mathrm{T}$ & Temperature-dependent olivine crystallization rate $\left({ }^{\circ} \mathrm{C}^{-1}\right)$ \\
\hline$\lambda$ & Fanning friction factor between lava and substrate \\
\hline$\mu_{\mathrm{s}}$ & Viscosity of molten substrate $(\mathrm{Pa} \cdot \mathrm{s})$ \\
\hline$\mu_{1}$ & Bulk viscosity of lava $(\mathrm{Pa} \cdot \mathrm{s})$ \\
\hline$\rho_{1}$ & Bulk density of lava $\left(\mathrm{kg} \cdot \mathrm{m}^{-3}\right)$ \\
\hline$\rho_{\mathrm{s}}$ & Bulk density of substrate $\left(\mathrm{kg} \cdot \mathrm{m}^{-3}\right)$ \\
\hline$\Omega$ & Flow power per unit width $\left(\mathrm{W} \cdot \mathrm{m}^{-2}\right)$ \\
\hline $\mathrm{c}_{1}$ & Specific heat capacity of lava $\left(\mathrm{J} \cdot \mathrm{kg}^{-1} \cdot{ }^{\circ} \mathrm{C}^{-1}\right)$ \\
\hline $\mathrm{c}_{\mathrm{s}}$ & Specific heat capacity of substrate $\left(\mathrm{J} \cdot \mathrm{kg}^{-1}\right.$, \\
\hline $\mathrm{E}_{\mathrm{ms}}$ & Thermal energy per unit volume required to melt substrate $\left(\mathrm{J} \cdot \mathrm{m}^{-3}\right)$ \\
\hline $\mathrm{E}_{\mathrm{hs}}$ & Thermal energy per unit volume required to heat substrate $\left(\mathrm{J} \cdot \mathrm{m}^{-3}\right)$ \\
\hline $\mathrm{f}_{\mathrm{p}}$ & Pore space fraction in substrate \\
\hline $\mathrm{f}_{\mathrm{ms}}$ & Substrate melting fraction for thermo-méchanical erosion \\
\hline $\mathrm{g}$ & Surface gravity at the equator of Mars $\left(\mathrm{m} \cdot \mathrm{s}^{-2}\right)$ \\
\hline $\mathrm{h}$ & Flow thickness (m) \\
\hline $\mathrm{h}_{\mathrm{T}}$ & Heat transfer coefficient $\left(\mathrm{W} \cdot \mathrm{m}^{-2} \cdot{ }^{\circ} \mathrm{C}^{-1}\right)$ \\
\hline $\mathrm{k}_{1}$ & Thermal conductivity of lava $\left(\mathrm{W} \cdot \mathrm{m}^{-1} \cdot{ }^{\circ} \mathrm{C}^{-1}\right)$ \\
\hline $\mathrm{K}_{\mathrm{s}}$ & Mechanical erodibility constant of substrate $\left(\mathrm{Pa}^{-1}\right)$ \\
\hline $\mathrm{L}_{1}$ & Latent heat of laya crystallisation $\left(\mathrm{J} \cdot \mathrm{kg}^{-1}\right)$ \\
\hline $\mathrm{L}_{\mathrm{s}}$ & Latent heat of fusion of substrate $\left(\mathrm{J} \cdot \mathrm{kg}^{-1}\right)$ \\
\hline $\mathrm{Mi}^{\text {melt }}$ & Oxide mass fraction in the melt fraction of lava \\
\hline $\mathrm{Mi}^{\text {ass }}$ & Oxide mass fraction in the assimilant \\
\hline $\mathrm{Mi}^{\mathrm{ol}}$ & Oxide mass fraction in crystallizing olivine \\
\hline $\mathrm{P}_{\mathrm{e}}$ & Equilibrium pressure of the melt and gas phase (bar) \\
\hline $\mathrm{P}_{\mathrm{m}}$ & Mantle melting pressure $(\mathrm{Pa})$ \\
\hline $\operatorname{Pr}$ & Prandtl number \\
\hline Q & Flow rate per unit width $\left(\mathrm{m}^{2} \cdot \mathrm{s}^{-1}\right)$ \\
\hline $\mathrm{R}$ & Universal gas constant $\left(\mathrm{J} \cdot \mathrm{mol}^{-1} \cdot{ }^{\circ} \mathrm{C}^{-1}\right)$ \\
\hline & Reynolds number \\
\hline & Eruption temperature of lava $\left({ }^{\circ} \mathrm{C}\right)$ \\
\hline $\mathrm{T}_{\text {liq }}$ & Liquidus temperature of lava $\left({ }^{\circ} \mathrm{C}\right)$ \\
\hline $\mathrm{T}_{\mathrm{sol}}$ & Solidus temperature of lava $\left({ }^{\circ} \mathrm{C}\right)$ \\
\hline $\mathrm{T}_{\mathrm{a}}$ & Ambient temperature $\left({ }^{\circ} \mathrm{C}\right)$ \\
\hline $\mathrm{T}_{\mathrm{m}}$ & Mantle melting temperature $\left({ }^{\circ} \mathrm{C}\right)$ \\
\hline $\mathrm{T}_{\mathrm{ms}}$ & Melting temperature of substrate $\left({ }^{\circ} \mathrm{C}\right)$ \\
\hline $\mathrm{u}$ & Total lava erosion rate $\left(\mathrm{m} \cdot \mathrm{s}^{-1}\right.$ or $\mathrm{m} \cdot \mathrm{d}^{-1}-$ meter per day $)$ \\
\hline $\mathrm{u}_{\mathrm{mech}}$ & Mechanical lava erosion rate $\left(\mathrm{m} \cdot \mathrm{s}^{-1}\right.$ or $\mathrm{m} \cdot \mathrm{d}^{-1}-$ meter per day $)$ \\
\hline $\mathrm{u}_{\mathrm{therm}}$ & Thermo-mechanical lava erosion rate $\left(\mathrm{m} \cdot \mathrm{s}^{-1}\right.$ or $\mathrm{m} \cdot \mathrm{d}^{-1}-$ meter per day) \\
\hline
\end{tabular}




\begin{tabular}{ll}
$\mathrm{v}$ & Lava flow velocity $\left(\mathrm{m} \cdot \mathrm{s}^{-1}\right)$ \\
$\mathrm{w}_{\mathrm{g}}$ & Weight fraction of gas in lava \\
$\mathrm{x}$ & Incremental calculation step \\
$\mathrm{X}$ & Mass fraction of crystals in lava \\
$\mathrm{X}^{\prime}(\mathrm{T})$ & Rate of change of crystal fraction with temperature $\left({ }^{\circ} \mathrm{C}^{-1}\right)$ \\
\hline
\end{tabular}

Table 2. Physical and chemical lava parameters.

\begin{tabular}{|c|c|c|c|}
\hline Lava type & ADR & LDM & Y98 \\
\hline \multicolumn{4}{|c|}{ Chemical composition } \\
\hline $\mathrm{SiO}_{2}(\mathrm{wt} \%)$ & 46.96 & 44.13 & 50.14 \\
\hline $\mathrm{TiO}_{2}$ & 0.56 & 1.11 & 0.48 \\
\hline $\mathrm{Al}_{2} \mathrm{O}_{3}$ & 10.93 & 11.21 & 6.09 \\
\hline $\mathrm{FeO}$ & 19.23 & 16.16 & 16.03 \\
\hline $\mathrm{MnO}$ & 0.42 & 0.46 & 0.44 \\
\hline $\mathrm{MgO}$ & 10.65 & 10.71 & 18.37 \\
\hline $\mathrm{CaO}$ & 8.02 & 8.28 & 7.31 \\
\hline $\mathrm{Na}_{2} \mathrm{O}$ & 2.56 & 4.14 & 0.81 \\
\hline $\mathrm{K}_{2} \mathrm{O}$ & 0.10 & 97 & 0.02 \\
\hline $\mathrm{P}_{2} \mathrm{O}_{5}$ & 0.57 & & 0.31 \\
\hline$S(p p m)$ & & & 3000 \\
\hline \multicolumn{4}{|c|}{ Physical parameters } \\
\hline $\mathrm{P}_{\mathrm{m}}(\mathrm{GPa})$ & 1.3 & 2.2 & 1.2 \\
\hline $\mathrm{T}_{\mathrm{m}}\left({ }^{\circ} \mathrm{C}\right)$ & 1380 & 1350 & 1540 \\
\hline $\mathrm{T}_{0}\left({ }^{\circ} \mathrm{C}\right)$ & $1260-136$ & 260-134 & $1420-1520$ \\
\hline $\mathrm{T}_{\mathrm{liq}}\left({ }^{\circ} \mathrm{C}\right)$ & 125 & 1310 & 1430 \\
\hline $\mathrm{k}_{1}\left(\mathrm{~J} \cdot \mathrm{m}^{-1} \cdot \mathrm{s}^{-1} \cdot{ }^{\circ} \mathrm{C}^{-1}\right)$ & & 2 & \\
\hline $\mathrm{L}_{\mathrm{l}}\left(\mathrm{J} \cdot \mathrm{kg}^{-1}\right)$ & & $5 \cdot 10^{5}$ & \\
\hline$f \mathrm{O}_{2}(\Delta \mathrm{QFM})$ & & 4 and $\mathrm{Q}$ & \\
\hline
\end{tabular}

$\mathrm{ADR}=$ Noachian-Hesperian Adirondack-class basalt; LDM $=$ Amazonian low-degree mantle melt; Y98 = Amazonian Y-980459 olivine-phyric shergottite. See text for discussion on parameter estimates and Table 1 for parameter abbreviations.

Table 3. Physical and chemical substrate parameters.

\begin{tabular}{lcc}
\hline Substrate type & Sulfide-rich substrate & Sulfate-rich substrate \\
\hline Chemical composition & & \\
$\mathrm{SiO}_{2}(\mathrm{wt} \%)$ & 49.76 & 45.11 \\
$\mathrm{TiO}_{2}$ & 1.03 & 0.88 \\
$\mathrm{Al}_{2} \mathrm{O}_{3}$ & 11.73 & 10.22 \\
$\mathrm{FeO}$ & 13.60 & 19.28 \\
$\mathrm{MnO}$ & 0.30 & 0.42 \\
$\mathrm{MgO}$ & 8.18 & 9.71 \\
$\mathrm{CaO}$ & 9.35 & 7.68 \\
$\mathrm{Na}$ & 3.91 & 2.65 \\
$\mathrm{~K}_{2} \mathrm{O}$ & 0.34 & 0.31 \\
$\mathrm{P}_{2} \mathrm{O}_{5}$ & 0.79 & 0.74 \\
$\mathrm{~S}_{5} \mathrm{SO}_{3}$ & 1.00 & 3.00
\end{tabular}


Physical parameters

$\rho_{\mathrm{s}}\left(\mathrm{kg} \cdot \mathrm{m}^{-3}\right)$

3000

2500

$\mathrm{c}_{\mathrm{s}}\left(\mathrm{J} \cdot \mathrm{K}^{-1} \cdot \mathrm{kg}^{-1}\right)$

1500

1200

$\mathrm{L}_{\mathrm{s}}\left(\mathrm{J} \cdot \mathrm{kg}^{-1}\right)$

$4 \cdot 10^{5}$

$\mathrm{T}_{\mathrm{ms}}\left({ }^{\circ} \mathrm{C}\right)$

1100

$\mathrm{f}_{\mathrm{ms}}$

0.2

See text for discussion on parameter estimates and Table 1 for parameter abbreviations.

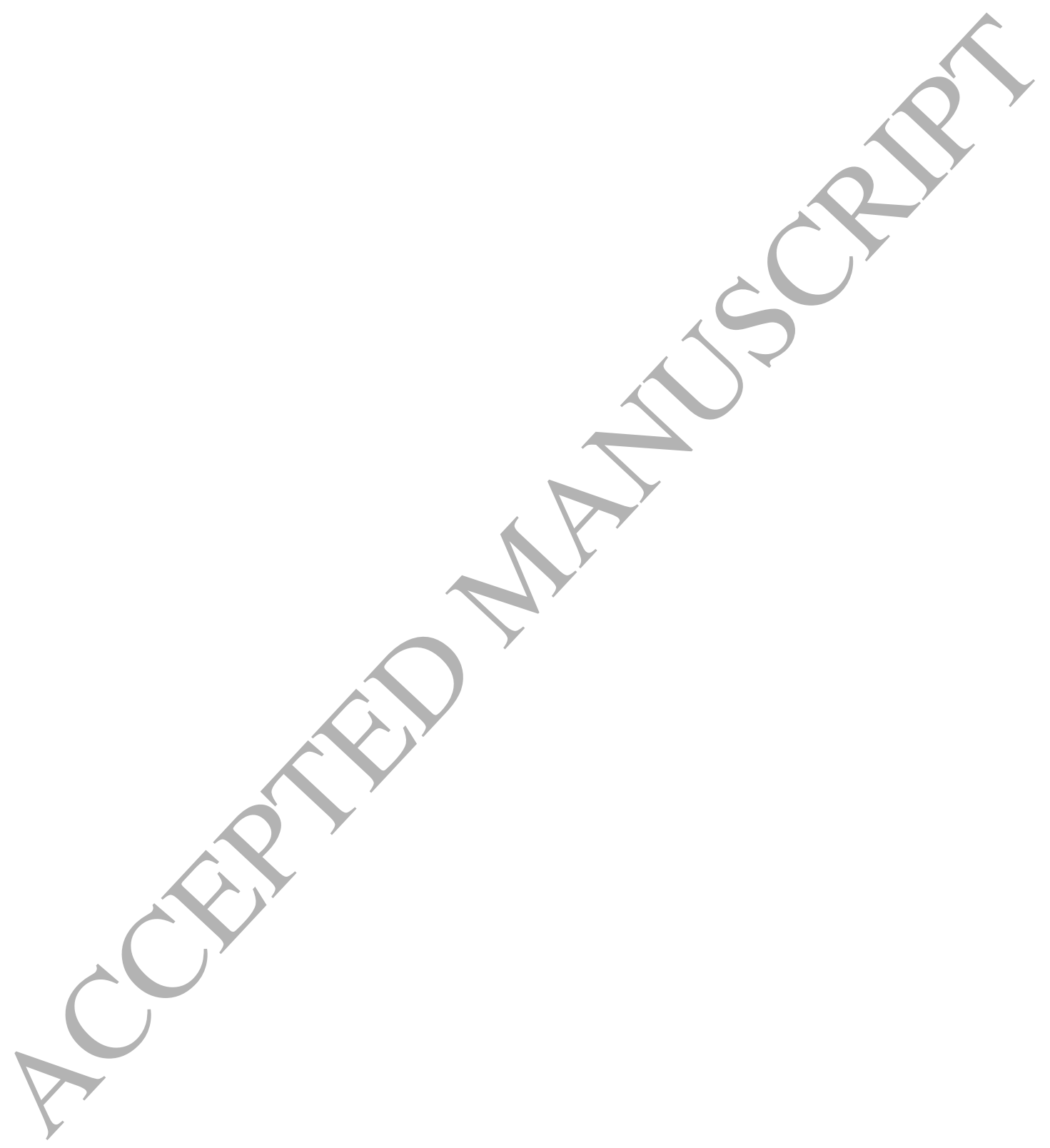


Table. 4. Results of isobaric and isothermal closed-system melt-gas equilibrium calculations in the C-H-O-S fluid system for the stepwise assimilation of anhydrous $\left(\mathrm{XSO}_{4}\right)$ and hydrous $\left(\mathrm{XSO}_{4} \cdot 2 \mathrm{H}_{2} \mathrm{O}\right)$ sulfate by martian mantle melts.

\begin{tabular}{|c|c|c|c|c|c|c|c|c|c|c|c|c|}
\hline $\begin{array}{c}\mathrm{SO}_{3} \\
\text { assimilat } \\
\text { lava } \\
\text { wt } \%\end{array}$ & $\begin{array}{c}\text { Gas } \\
\text { fraction } \\
\text { lava } \\
\text { wt } \%\end{array}$ & $\begin{array}{c}\mathrm{XH}_{2} \mathrm{O} \\
\text { gas }\end{array}$ & $\begin{array}{l}\mathrm{XH}_{2} \\
\text { gas }\end{array}$ & $\begin{array}{c}\mathrm{XH}_{2} \mathrm{~S} \\
\text { gas }\end{array}$ & $\begin{array}{c}\mathrm{XSO}_{2} \\
\text { gas }\end{array}$ & $\begin{array}{l}\mathrm{XS}_{2} \\
\text { gas }\end{array}$ & $\mathrm{XCO}$ & $\mathrm{XCO}_{2}$ & $\triangle \mathrm{QFI}$ & $S^{6+/ 2 S}$ & $\begin{array}{l}\text { melt } \\
\text { ppm }\end{array}$ & $\begin{array}{l}\mathrm{S}^{6+} \\
\text { melt } \\
\mathrm{ppm}\end{array}$ \\
\hline \multicolumn{13}{|c|}{ Simulation 1, ADR, Assimilant $=\mathrm{XSO}_{4}, \mathrm{Pe}=5 \mathrm{bar}, \mathrm{T}=1350^{\circ} \mathrm{C}, f \mathrm{O}_{2}=\mathrm{QFM}-4, \mathrm{~S}=1500 \mathrm{ppm}, \mathrm{FeO}=20 \mathrm{wt} \%$} \\
\hline 0.00 & $<0.001$ & 0.433 & 0.378 & 0.009 & $<0.001$ & $<0.001$ & 0.131 & 0.048 & -3.92 & $1.1 \mathrm{E}-10$ & 1500 & $<1$ \\
\hline 0.10 & $<0.001$ & 0.596 & 0.103 & 0.017 & 0.003 & 0.001 & 0.098 & & -1.94 & $1.0 \mathrm{E}-06$ & 1747 & $<1$ \\
\hline 0.20 & 0.001 & 0.589 & 0.033 & 0.020 & 0.122 & 0.019 & 0.032 & 0.186 & -0.95 & $1.0 \mathrm{E}-04$ & 2073 & $<1$ \\
\hline 0.30 & 0.002 & 0.477 & 0.018 & 0.016 & 0.357 & 0.038 & 0.010 & 0.083 & -0.64 & 4.2E-04 & 2067 & 1 \\
\hline 0.40 & 0.004 & 0.399 & 0.014 & 0.013 & 0.475 & 0.043 & 0.006 & 0.052 & -0.54 & $6.6 \mathrm{E}-04$ & 1946 & 1 \\
\hline 0.55 & 0.006 & 0.328 & 0.010 & 0.009 & 0.573 & 0.042 & 0. & 0.034 & -0.45 & $1.0 \mathrm{E}-03$ & 1746 & 2 \\
\hline 0.70 & 0.007 & 0.282 & 0.008 & 0.007 & 0.636 & 0.038 & 0.002 & 0.026 & -0.39 & $1.3 \mathrm{E}-03$ & 1553 & 2 \\
\hline 0.85 & 0.009 & 0.249 & 0.007 & 0.006 & 0.682 & 0.034 & 0.002 & 0.021 & -0.33 & $1.7 \mathrm{E}-03$ & 1371 & 2 \\
\hline 1.00 & 0.010 & 0.225 & 0.006 & 0.004 & 0.716 & .02 & 0.001 & 0.018 & -0.28 & $2.2 \mathrm{E}-03$ & 1202 & 3 \\
\hline \multicolumn{13}{|c|}{ Simulation 2, ADR, Assimilant $=\mathrm{XSO}_{4}, \mathrm{P}_{\mathrm{e}}=100 \mathrm{bar}, \mathrm{T}=1350^{\circ} \mathrm{C}, f \mathrm{O}_{2}=\mathrm{QFM}-4, \mathrm{~S}=1500 \mathrm{ppm}, \mathrm{FeO}=20 \mathrm{wt} \%$} \\
\hline 0.00 & $<0.001$ & 0.035 & 0.064 & 0.001 & $<0.001$ & $<0.001$ & 0.767 & 0.133 & -4.00 & 7.9E-11 & 1500 & $<1$ \\
\hline 0.10 & $<0.001$ & 0.036 & 0.007 & 0.001 & $<0.001$ & $<0.001$ & 0.348 & 0.609 & -1.99 & 8.3E-07 & 1750 & $<1$ \\
\hline 0.20 & $<0.001$ & 0.036 & 0.002 & 0.001 & 0.009 & 0.001 & 0.127 & 0.824 & -0.85 & $1.6 \mathrm{E}-04$ & 2149 & $<1$ \\
\hline 0.30 & $<0.001$ & 0.036 & 0.001 & 0.001 & & 0.010 & 0.048 & 0.753 & -0.08 & $5.5 \mathrm{E}-03$ & 2518 & 14 \\
\hline 0.40 & 0.001 & 0.036 & $<0.001$ & 0.00 & 0.390 & 0.028 & 0.013 & 0.324 & 0.30 & $3.1 \mathrm{E}-02$ & 2677 & 85 \\
\hline 0.55 & 0.002 & 0.035 & $<0.001$ & 0.001 & 0.824 & 0.032 & 0.004 & 0.102 & 0.41 & $5.0 \mathrm{E}-02$ & 2541 & 133 \\
\hline 0.70 & 0.003 & 0.035 & $<0.001$ & 0.001 & 0.874 & 0.030 & 0.002 & 0.058 & 0.45 & 5.9E-02 & 2346 & 148 \\
\hline 0.85 & 0.005 & 0.034 & $<0.001$ & 0.001 & 0.896 & 0.027 & 0.001 & 0.040 & 0.48 & $6.8 \mathrm{E}-02$ & 2153 & 156 \\
\hline 1.00 & 0.007 & 0.033 & $<0.001$ & 0.001 & 0.909 & 0.024 & 0.001 & 0.031 & 0.51 & 7.7E-02 & 1964 & 163 \\
\hline
\end{tabular}

Simulation 3, ADR, Assimilant $=\mathrm{XSO}_{4} \cdot 2 \mathrm{H}_{2} \mathrm{O}, \mathrm{P}_{\mathrm{e}}=5 \mathrm{bar}, \mathrm{T}=1350{ }^{\circ} \mathrm{C}, f \mathrm{O}_{2}=\mathrm{QFM}-2, \mathrm{~S}=1500 \mathrm{ppm}, \mathrm{FeO}=20 \mathrm{wt} \%$
0.00
$<0.00$

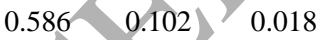
0.004
$0.002 \quad 0.102$
0.187
-1.95 1.0E-06 1500
$<1$ 


$\begin{array}{cccccccccccccc}0.10 & 0.001 & 0.711 & 0.042 & 0.026 & 0.107 & 0.019 & 0.015 & 0.080 & -1.01 & 7.6 \mathrm{E}-05 & 1594 & <1 \\ 0.20 & 0.002 & 0.661 & 0.030 & 0.023 & 0.218 & 0.028 & 0.005 & 0.035 & -0.79 & 2.1 \mathrm{E}-04 & 1484 & <1 \\ 0.30 & 0.004 & 0.634 & 0.026 & 0.019 & 0.267 & 0.028 & 0.003 & 0.022 & -0.69 & 3.3 \mathrm{E}-04 & 1324 & <1 \\ 0.40 & 0.005 & 0.621 & 0.024 & 0.017 & 0.295 & 0.025 & 0.002 & 0.016 & -0.63 & 4.4 \mathrm{E}-04 & 1169 & 1 \\ 0.55 & 0.007 & 0.611 & 0.021 & 0.014 & 0.321 & 0.021 & 0.001 & 0.012 & -0.55 & 6.3 \mathrm{E}-04 & 964 & 1 \\ 0.70 & 0.010 & 0.606 & 0.019 & 0.011 & 0.337 & 0.016 & 0.001 & 0.009 & -0.48 & 8.7 \mathrm{E}-04 & 788 & 1 \\ 0.85 & 0.012 & 0.605 & 0.018 & 0.009 & 0.348 & 0.012 & 0.001 & 0.008 & -0.40 & 1.3 \mathrm{E}-03 & 635 & 1 \\ 1.00 & 0.014 & 0.605 & 0.016 & 0.007 & 0.356 & 0.009 & 0.001 & 0.007 & -0.33 & 1.7 \mathrm{E}-03 & 501 & 1 \\ \text { Simulation } & 4, \mathrm{Y} 98, \mathrm{Assimilant} & \mathrm{XSO} \mathrm{XS}_{4}, \mathrm{P}_{\mathrm{e}}=5 \mathrm{bar}, \mathrm{T}=1500{ }^{\circ} \mathrm{C}, \mathrm{fO} 2=\mathrm{QFM}-4, \mathrm{~S}=1500 \mathrm{ppm}, \mathrm{FeO}=16 \mathrm{wt} \% & & \\ 0.00 & <0.001 & 0.438 & 0.372 & 0.009 & <0.001 & <0.001 & 0.137 & 0.043 & -3.91 & 1.2 \mathrm{E}-10 & 1495 & <1 \\ 0.10 & <0.001 & 0.600 & 0.086 & 0.015 & 0.024 & 0.005 & 0.094 & 0.176 & -1.71 & 3.0 \mathrm{E}-06 & 1882 & <1 \\ 0.20 & 0.001 & 0.513 & 0.032 & 0.014 & 0.290 & 0.029 & 0.023 & 0.098 & -1.00 & 7.9 \mathrm{E}-05 & 1998 & <1 \\ 0.30 & 0.002 & 0.418 & 0.022 & 0.010 & 0.448 & 0.036 & 0.011 & 0.054 & -0.86 & 1.5 \mathrm{E}-04 & 1881 & <1 \\ 0.40 & 0.003 & 0.358 & 0.018 & 0.008 & 0.534 & 0.037 & 0.007 & 0.038 & -0.79 & 2.1 \mathrm{E}-04 & 1743 & <1 \\ 0.60 & 0.006 & 0.275 & 0.011 & 0.004 & 0.659 & 0.025 & 0.003 & 0.022 & -0.61 & 4.8 \mathrm{E}-04 & 1175 & 1 \\ 0.80 & 0.007 & 0.243 & 0.009 & 0.003 & 0.703 & 0.021 & 0.003 & 0.018 & -0.55 & 6.3 \mathrm{E}-04 & 1002 & 1 \\ 1.00 & 0.009 & 0.219 & 0.008 & 0.002 & 0.737 & 0.017 & 0.002 & 0.015 & -0.48 & 8.7 \mathrm{E}-04 & 838 & 1\end{array}$

Simulation 5, Y98, Assimilant $=\mathrm{XSO}_{4}, \mathrm{P}_{\mathrm{e}}=100 \mathrm{bar}, \mathrm{T}=1500{ }^{\circ} \mathrm{C}, \mathrm{fO}_{2}=\mathrm{QFM}-4, \mathrm{~S}=3000 \mathrm{ppm}, \mathrm{FeO}=16 \mathrm{wt} \%$

$\begin{array}{lllllllllllll}0.00 & <0.001 & 0.028 & 0.046 & 0.001 & <0.001 & <0.001 & 0.793 & 0.132 & -3.82 & 1.8 \mathrm{E}-10 & 2962 & <1\end{array}$

$\begin{array}{lllllllllllll}0.10 & <0.001 & 0.029 & 0.004 & 0.001 & 0.002 & 0.001 & 0.341 & 0.622 & -1.74 & 2.6 \mathrm{E}-06 & 3362 & <1\end{array}$

$\begin{array}{lllllllllllll}0.20 & <0.001 & 0.029 & 0.001 & 0.001 & 0.110 & 0.013 & 0.109 & 0.736 & -0.60 & 5.0 \mathrm{E}-04 & 3720 & 2\end{array}$

$\begin{array}{lllllllllllll}0.30 & 0.001 & 0.029 & 0.001 & 0.001 & 0.495 & 0.036 & 0.036 & 0.401 & -0.17 & 3.6 \mathrm{E}-03 & 3805 & 14\end{array}$

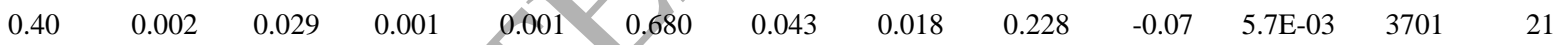

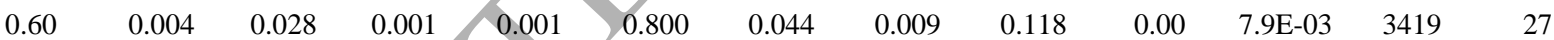

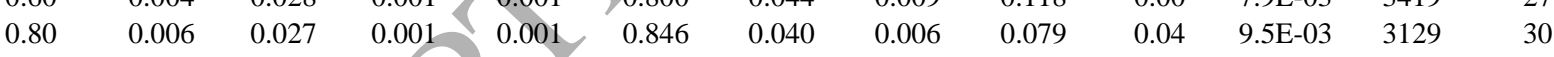

$\begin{array}{lllllllllllll}1.00 & 0.008 & 0.026 & <0.001 & 0.001 & 0.872 & 0.036 & 0.004 & 0.06 & 0.08 & 1.1 \mathrm{E}-02 & 2849 & 33\end{array}$

Simulation 6, Y98, Assimilant $=\mathrm{XSO}_{4}, \mathrm{P}_{\mathrm{e}}=5 \mathrm{bar}, \mathrm{T}=1350{ }^{\circ} \mathrm{C} ; \mathrm{O}_{2}=\mathrm{QFM}-2 ; \mathrm{S}=1500 \mathrm{ppm}, \mathrm{FeO}=16 \mathrm{wt} \%$

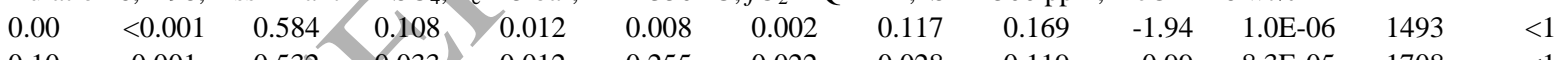

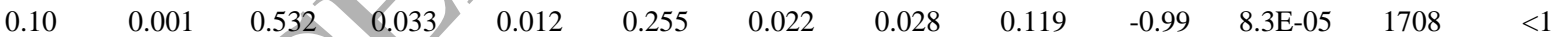




\begin{tabular}{|c|c|c|c|c|c|c|c|c|c|c|c|}
\hline 0.20 & 0.002 & 0.426 & 0.022 & 0.009 & 0.445 & 0.029 & 0.011 & 0.057 & -0.82 & $1.8 \mathrm{E}-04$ & 1743 \\
\hline 0.30 & 0.003 & 0.363 & 0.017 & 0.007 & 0.538 & 0.030 & 0.007 & 0.039 & -0.74 & & 1607 \\
\hline 0.40 & 0.004 & 0.320 & 0.014 & 0.006 & 0.597 & 0.028 & 0.005 & 0.030 & -0.68 & $3.5 \mathrm{E}-04$ & 1468 \\
\hline 0.55 & 0.006 & 0.275 & 0.011 & 0.004 & 0.659 & 0.025 & 0.003 & 0.022 & -0.61 & 4.8E-04 & 1269 \\
\hline 0.70 & 0.007 & 0.243 & 0.009 & 0.003 & 0.703 & 0.021 & 0.003 & 0.018 & & $6.3 \mathrm{E}-04$ & 1082 \\
\hline 0.85 & 0.009 & 0.219 & 0.008 & 0.002 & 0.737 & 0.017 & 0.002 & 0.015 & -0.4 & 8.7E-04 & 905 \\
\hline 1.00 & 0.010 & 0.200 & 0.006 & 0.002 & 0.764 & 0.013 & 0.002 & 0.013 & -0.41 & $1.2 \mathrm{E}-03$ & 742 \\
\hline
\end{tabular}

Simulation 7, Y98, Assimilant $=\mathrm{XSO}_{4}, \mathrm{P}_{\mathrm{e}}=5 \mathrm{bar}, \mathrm{T}=1500{ }^{\circ} \mathrm{C}, f \mathrm{O}_{2}=\mathrm{QFM}-2, \mathrm{~S}=0 \mathrm{ppm}, \mathrm{FeO}=16 \mathrm{wt} \%$

$\begin{array}{lllllllllllrr}0.00 & <0.001 & 0.590 & 0.109 & <0.001 & <0.001 & <0.001 & 0.123 & 0.178 & -1.93 & 1.1 \mathrm{E}-06 & 0 & <1 \\ 0.10 & <0.001 & 0.593 & 0.028 & 0.003 & 0.127 & 0.002 & 0.037 & 0.210 & -0.75 & 2.5 \mathrm{E}-04 & 371 & <1 \\ 0.20 & 0.001 & 0.476 & 0.016 & 0.002 & 0.410 & 0.004 & 0.010 & 0.081 & -0.43 & 1.1 \mathrm{E}-03 & 394 & <1 \\ 0.30 & 0.002 & 0.401 & 0.011 & 0.002 & 0.526 & 0.004 & 0.005 & 0.050 & -0.30 & 2.0 \mathrm{E}-03 & 326 & 1 \\ 0.40 & 0.003 & 0.352 & 0.009 & 0.001 & 0.594 & 0.003 & 0.004 & 0.038 & -0.20 & 3.2 \mathrm{E}-03 & 254 & 1 \\ 0.55 & 0.005 & 0.303 & 0.006 & 0.001 & 0.658 & 0.002 & 0.002 & 0.028 & -0.03 & 6.9 \mathrm{E}-03 & 158 & 1 \\ 0.70 & 0.006 & 0.269 & 0.004 & <0.001 & 0.702 & <0.001 & 0.001 & 0.023 & 0.17 & 1.7 \mathrm{E}-02 & 86 & 1 \\ 0.85 & 0.008 & 0.245 & 0.003 & <0.001 & 0.731 & <0.001 & 0.001 & 0.020 & 0.39 & 4.6 \mathrm{E}-02 & 42 & 2 \\ 1.00 & 0.009 & 0.225 & 0.002 & <0.001 & 0.755 & <0.001 & 0.001 & 0.017 & 0.63 & 1.3 \mathrm{E}-01 & 18 & 3\end{array}$

Simulation 8, Y98, Assimilant $=\mathrm{XSO}_{4}, \mathrm{P}_{\mathrm{e}}=5$ bar, $\mathrm{T}=1500{ }^{\circ} \mathrm{C}, \mathrm{fO}_{2}=\mathrm{QFM}-4, \mathrm{~S}=3000 \mathrm{ppm}, \mathrm{FeO}=16 \mathrm{wt} \%$

$\begin{array}{ccccccccccccc}0.00 & <0.001 & 0.435 & 0.369 & 0.017 & <0.001 & <0.001 & 0.135 & 0.043 & -3.91 & 1.2 \mathrm{E}-10 & 2991 & <1 \\ 0.10 & 0.001 & 0.587 & 0.086 & 0.026 & 0.039 & 0.015 & 0.087 & 0.159 & -1.73 & 2.8 \mathrm{E}-06 & 3362 & <1 \\ 0.20 & 0.002 & 0.484 & 0.036 & 0.022 & 0.295 & 0.060 & 0.023 & 0.081 & -1.15 & 4.0 \mathrm{E}-05 & 3375 & <1 \\ 0.30 & 0.003 & 0.396 & 0.026 & 0.017 & 0.430 & 0.072 & 0.012 & 0.048 & -1.02 & 7.2 \mathrm{E}-05 & 3201 & <1 \\ 0.40 & 0.006 & 0.342 & 0.021 & 0.014 & 0.507 & 0.074 & 0.008 & 0.035 & -0.96 & 9.5 \mathrm{E}-05 & 3021 & <1 \\ 0.60 & 0.007 & 0.275 & 0.011 & 0.004 & 0.659 & 0.025 & 0.003 & 0.022 & -0.61 & 4.8 \mathrm{E}-04 & 2821 & 1 \\ 0.80 & 0.009 & 0.243 & 0.009 & 0.003 & 0.703 & 0.021 & 0.003 & 0.018 & -0.55 & 6.3 \mathrm{E}-04 & 2626 & 2 \\ 1.00 & 0.010 & 0.219 & 0.008 & 0.002 & 0.737 & 0.017 & 0.002 & 0.015 & -0.48 & 8.7 \mathrm{E}-04 & 2414 & 2\end{array}$

See text, Table 2 and Table 3 for discussion of the physical and chemical model input parameters, and Table 1 for parameter abbreviations and entities. ADR = Noachian-Hesperian Adirondack-class basalt; Y98 = Amazonian Y-980459 olivine-phyric shergottite.

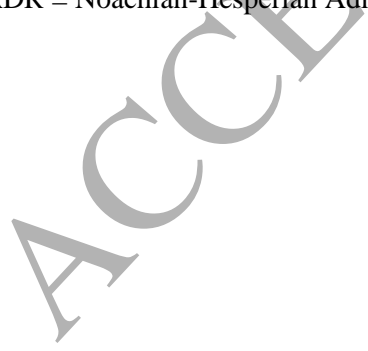

